فعالية برنامج ارشادي لتنمية الثفقة بالذات وتحسين الصمود النفسي لاى طلاب الجامعة

$$
\text { إعداد }
$$

$$
\text { د/ سهام علي عبد الغفار عليوه }
$$

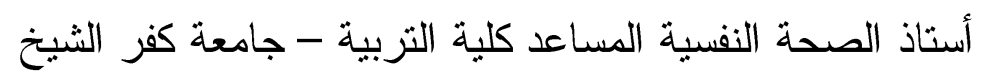

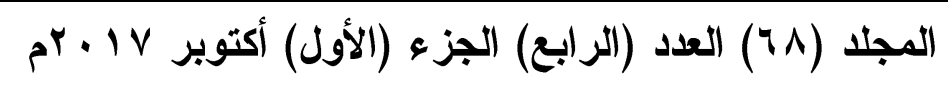


ملخص الار اسة - مانة

هدفت الدر اسة الحالية إلي التحقق من فعاليــة برنــامج التــدريب علــي الثــقة

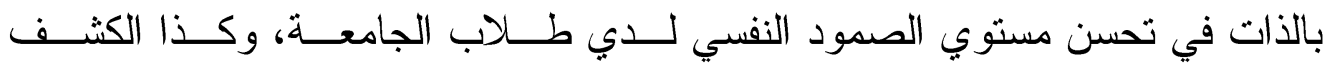
عن طبيعة العلاقة بين الشفقة بالذات و الصــمود النفسـي لــدي طــلاب الجامعــة، وتكونت عينة الدراسة الوصفية من ( . . ( ) طالب وطالبــة مــن الفـرق الدراســية

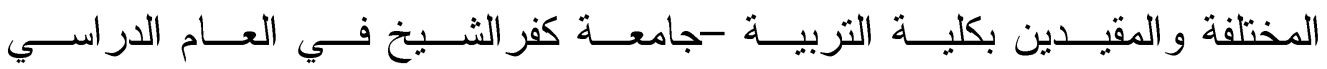
17

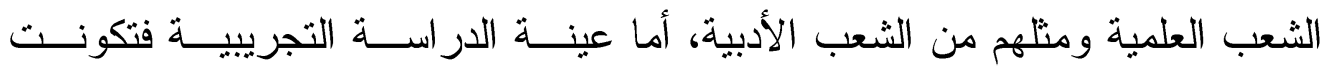

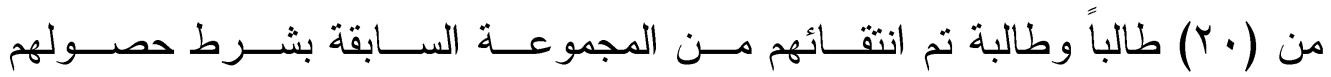

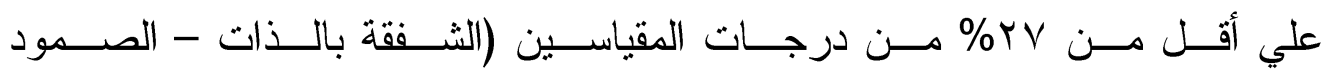
النفسي)، وتــم تقسـيم هــذه العينــهـ إلــي مجمــو عتين (تجريبيــة - ضـــابطة )

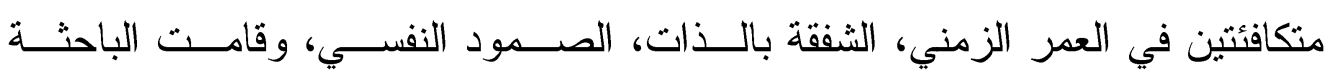

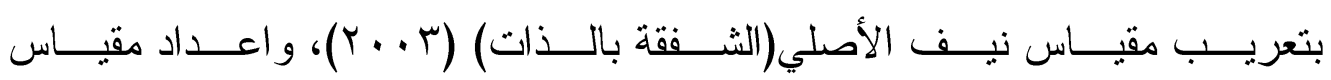

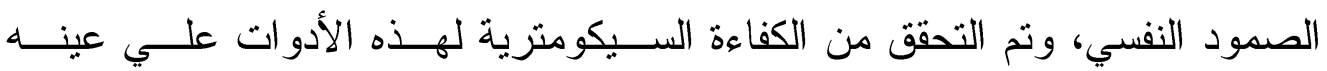

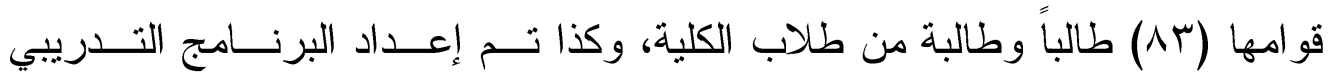
المستخدم في الدراسة، وقد أسفرت نتائج الدراسة عـن وجــود علاقــة ارتباطيــة دالة احصائياً بين الثفقة بالذات و الصدود النفسي لــدي طــلاب الجامعــة، فعاليـــة البرنامج التدريبي القائم علي الثفقة بالذات فـي تحســن مســتوي الثــفقة بالــذات و الصدود النفسي لدي طلاب الجامعة . 
Abstract :

The current study aims to check the effectiveness of the training program of self-compassion to improve the level of self-steadiness for university students. .The descriptive sample consisted of 100students from different stages in the faculty of Education ,University of Kafr Eshiekh in 2016/2017.The descriptive sample consisted from 50 boys and 50 girls in both literary and scientific branches .The empirical sample was 20 students and they were selected from the previous sample on the condition that they had $27 \%$ in the degrees of the two measures (self-compassion and selfsteadiness).This sample was divided into two equal samples (empirical -controlling )and equal in age .The researcher Arabized the original measures of Nef (2003)and set the measure of psychological steadiness. The effectiveness of the tools was checked by a 83 student sample and also the setting of the training $b$ program. The effectiveness of the program of self-compassion in improving the level of psychological self-compassion and selfsteadiness for university students .

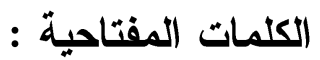

الثفقة بالذات self-Compassion - الصمود النفسي Psychological

Counselling Program البرنامج الارشادي - Resilience 
مما لا شك فيه إن مجتمعنا فى الوقت الحالى فى أثـــد الحاجــة إلــى تحقبــق

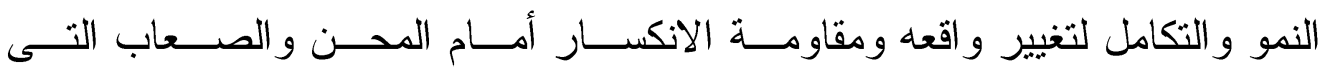

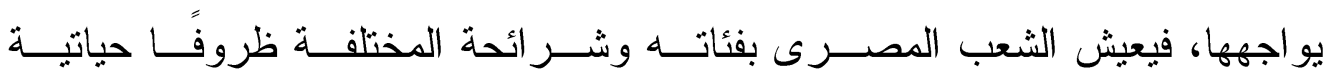
صعبة ، وكل هذه الظروف و العو امل تؤثز على شخصــية الفــرد وقدرتــهـ علــى

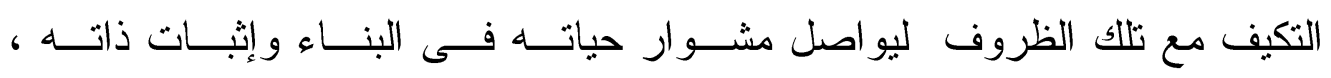

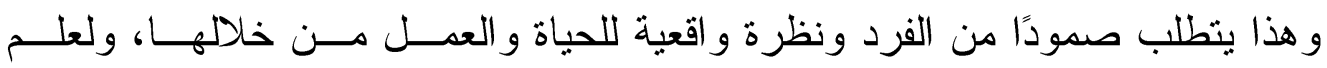

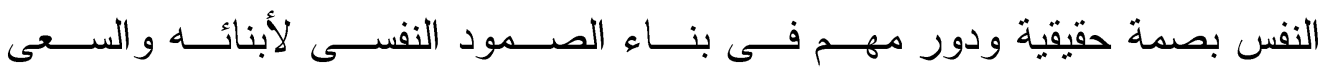
للازدهار فى هذا المجتمع.

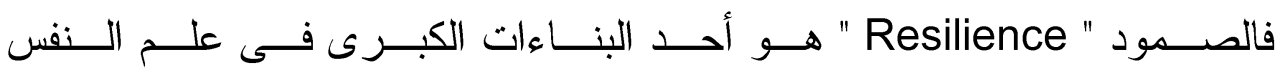

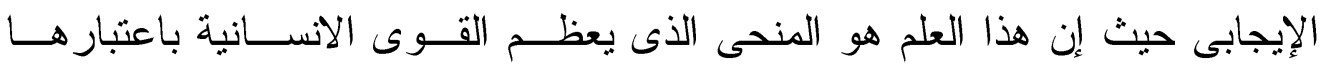
قوى أصلية فى الإنسان مقابل المناحى السائدة و الثــائعة و التــى تعظــم القصـــور

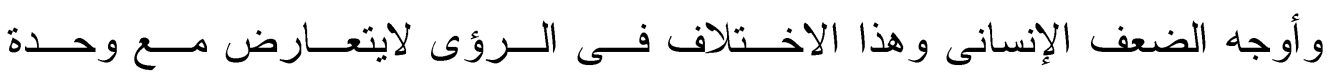
الهدف وهو تحقيق جودة الحياة . فقـــد عـــرف " ريتشاردســون" ( Richardson, 2002:313 ) الصـــمود

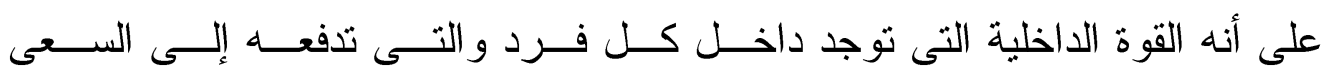
وتحقيق الإدر الك الذاتى والإيثار و الحكمة ويكون الفــرد فــى وئسـام وتتـــاغم مــع مصدر القوة الروحية. أما ماسـتين (Masten,2009:29) فيـري أن الصـــمود فــى علــم الــنفس يعنى القدرة على استعادة الفرد لتوازنه بعـــد التعــرض للمحــن و الصـــعاب ، بــلـ و قد يوظف هذه المحن و الصعاب لتحقيق النمو و التكامـلـل وهـــو بالتــالى مفهــوم دينامى يحمل فى معناه الثبات ، كما يحمل أيضًا فى معناه الحركة.

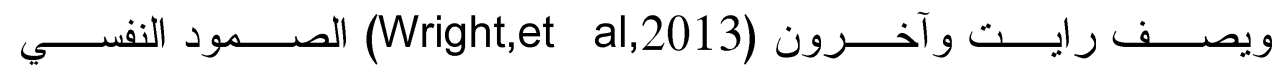
"Psychological Resilience"

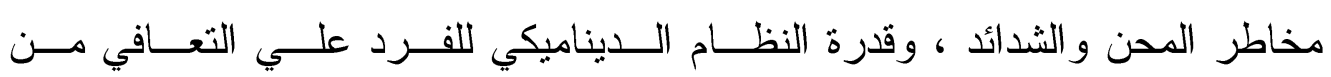

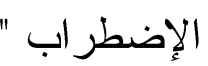


ونظر آلتعرض طلاب الجامعة إلي الكثير مـن التحـديات و الصــعاب التــي

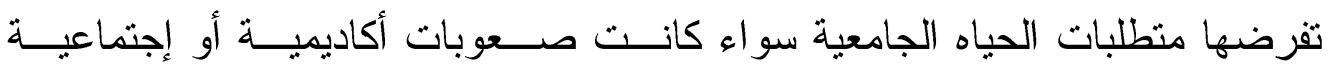

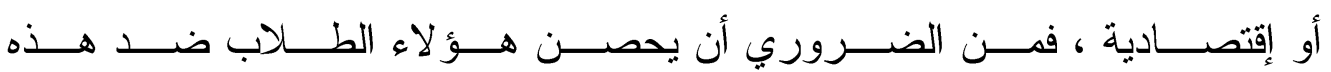

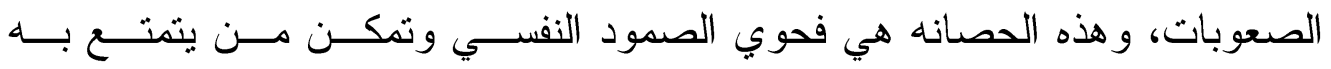

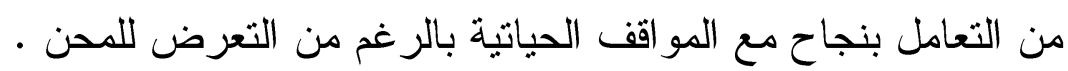

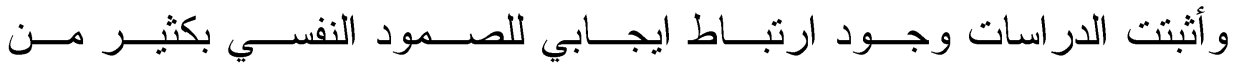

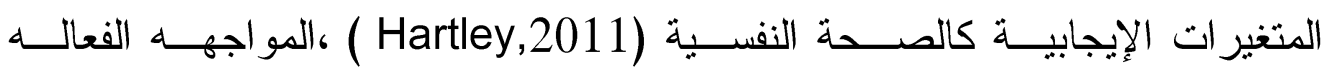

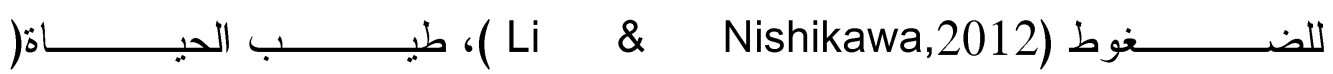

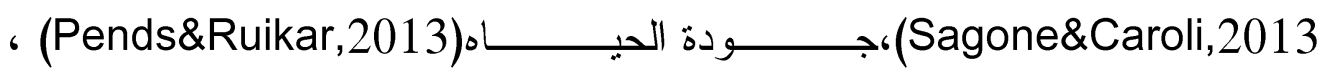

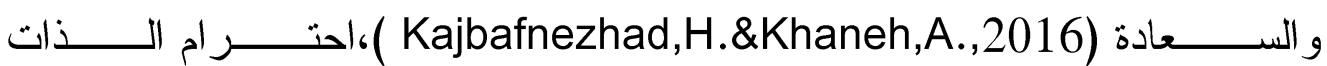

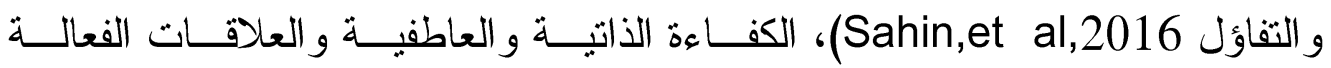
مع الآخرين( Aydogdu,et al,2017 ).

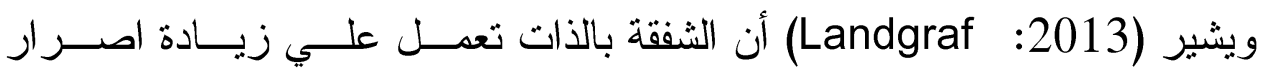

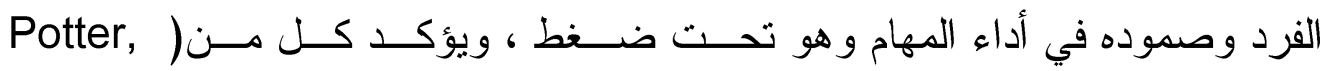

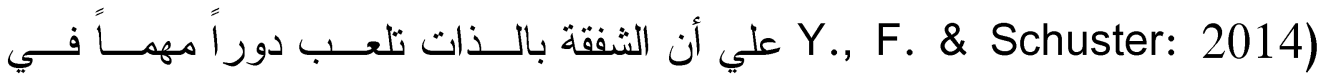
الحفاظ علي الفرد من الاضطر ابات النفسية .

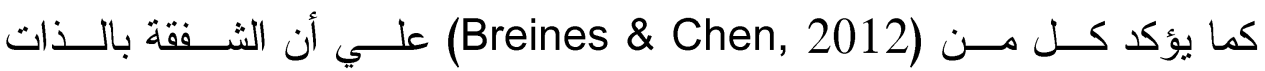

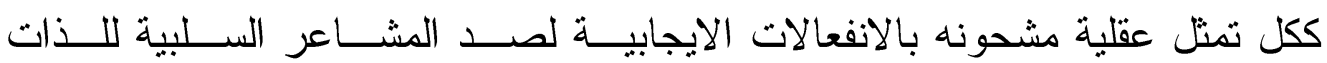

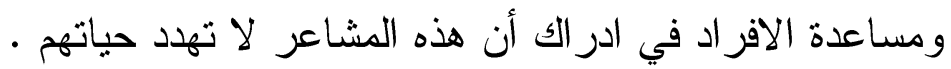
إن مفهوم الثفقة بالذات "Self-Compassion"مـن الدفــاهيم الحديثــة نســبيا

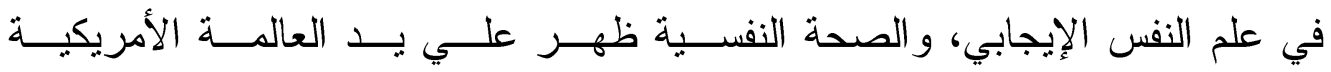

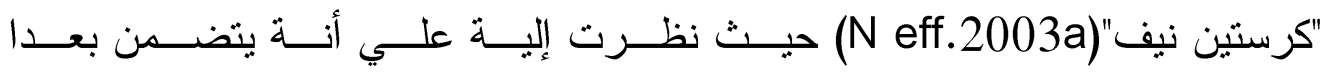

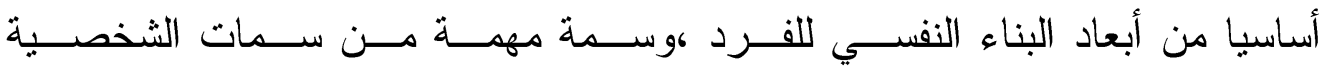

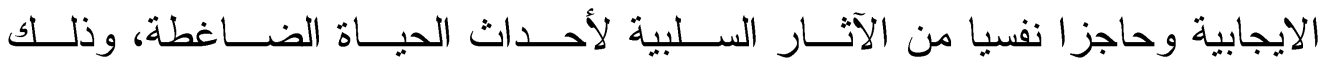

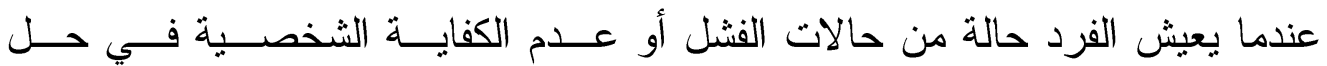

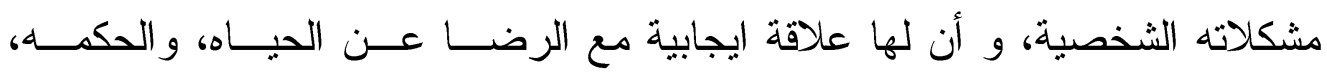




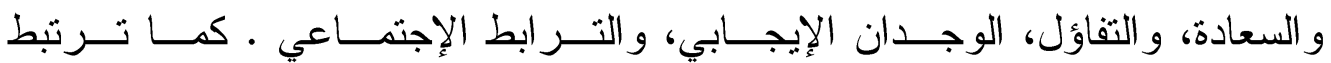

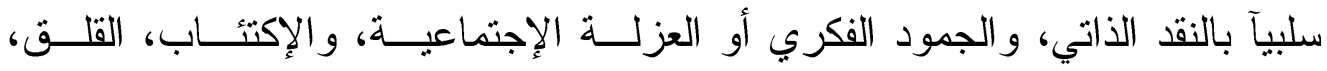

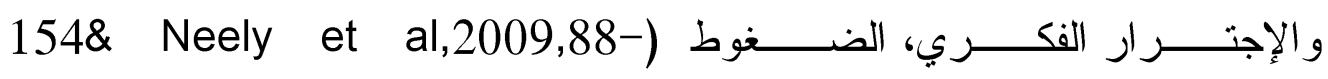
.(Neff.et a1.2007.139.97

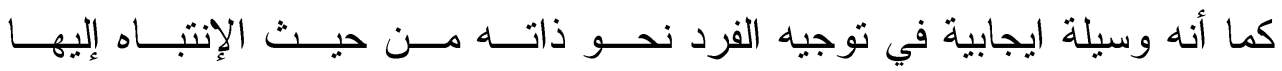

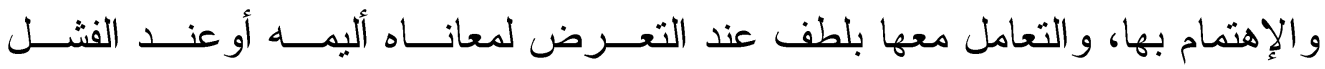
بدلآ من توجيه النقد اللاذع لها.

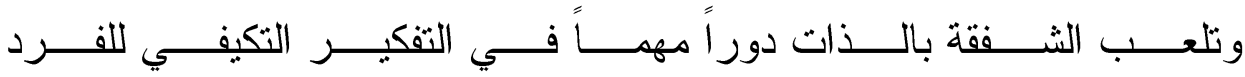
فــن خــال التـدريب علــي الثــفقة بالـــات يمكـن (ThinkingAdaptive)

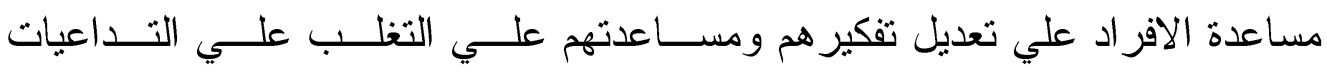

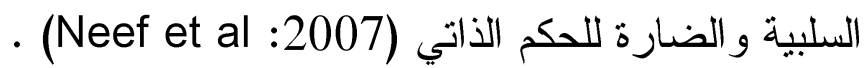

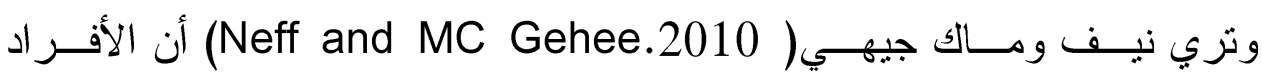

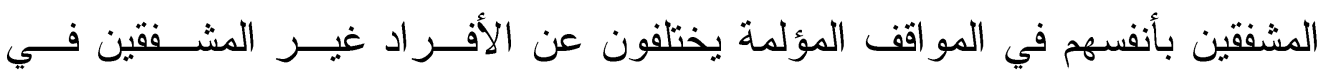

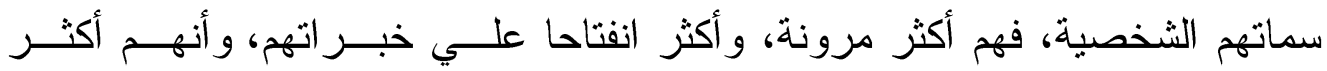

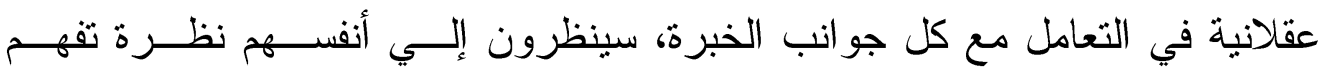

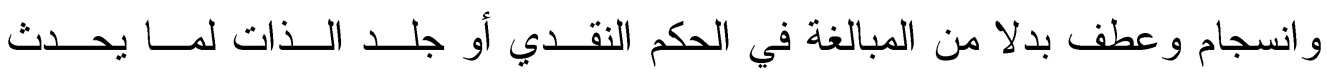

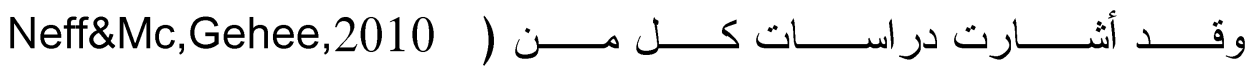

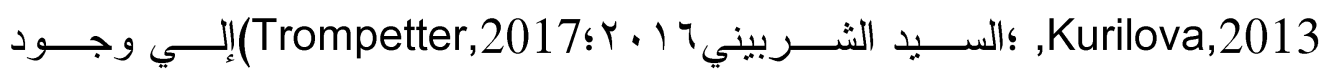

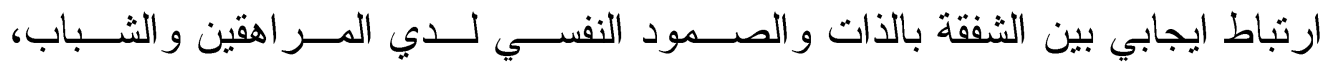

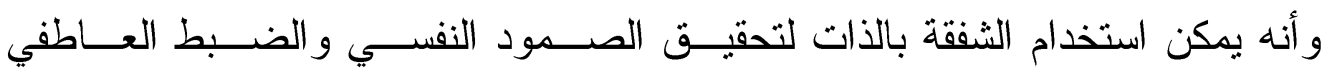

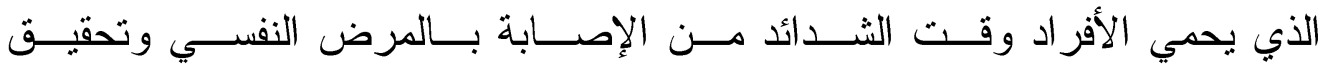

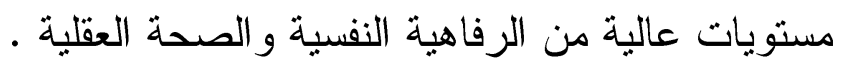

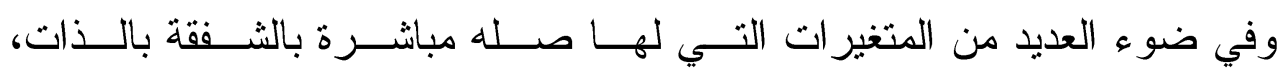

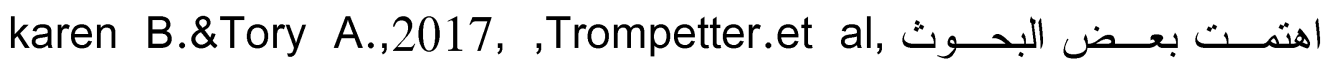
, (Amyfinlay et al ,2016, Tobias K.,et al 2016 (Bayir,A,2016 بتطوير أساليب تعزيـز الثــقة بالــات مــن خــلال تصــميم 
بر امج ارشادية قائمة علــي أبعــاد الثــفقة بالــذات وتعزيــز الرفاهيــة النفســية،

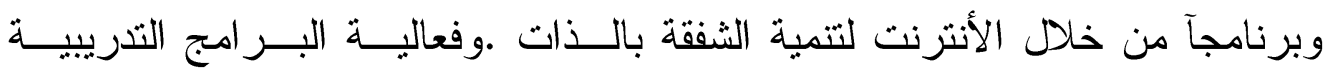

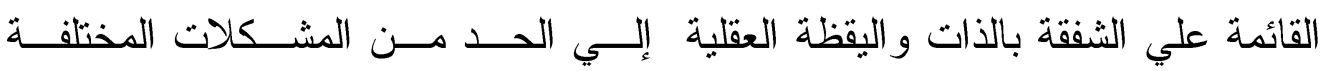

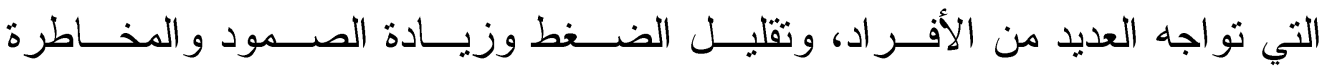

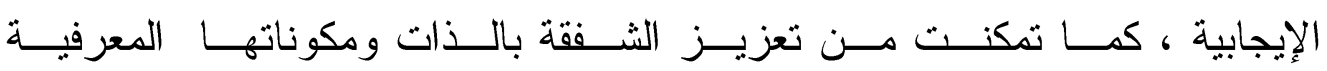

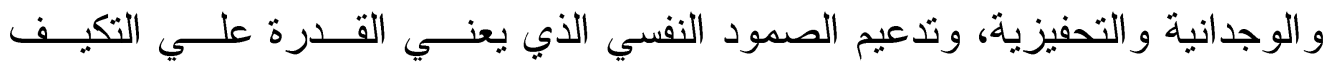

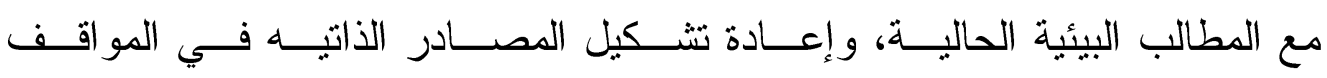

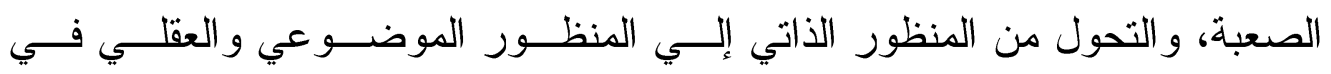

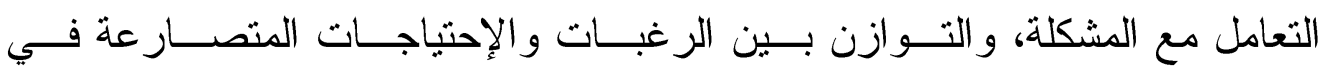

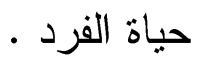
ويدعم ذلك ما أشارت إلبه Neff

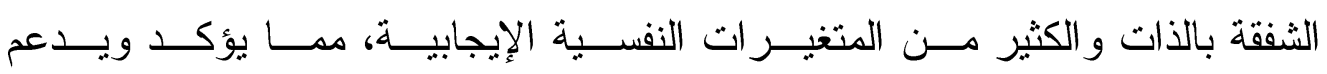

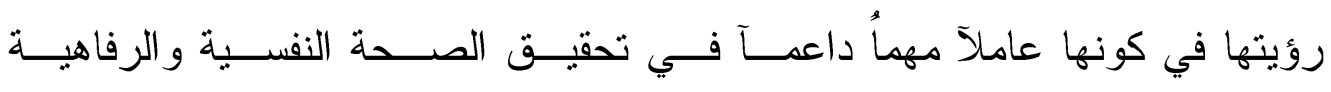
النفسية للفرد، وبالتالي ينصح بضروة استخدامها في التذخلات العلاجية. مشكلة الار اسة

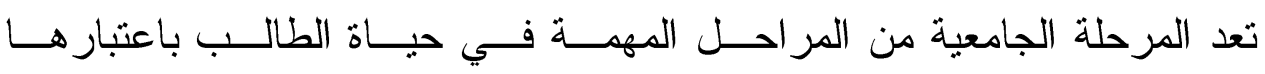

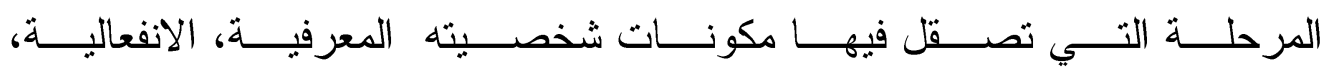

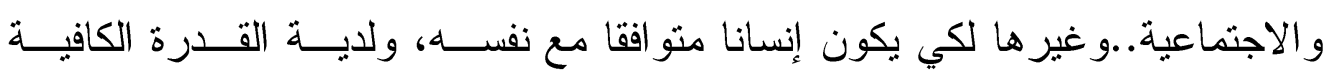
على مواجهة مشكلات المرحلة التي يعيشها و المر احل المستقبلية.

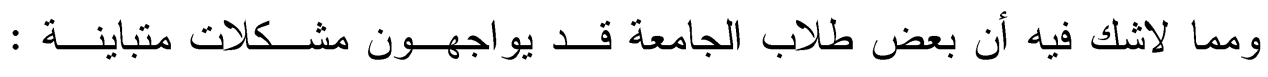
أكاديمية ونفسية و اجتماعية، إلا أنهم قد يتفاوتون فيما بيــنهم فــي كيفيــة التعامـلـل

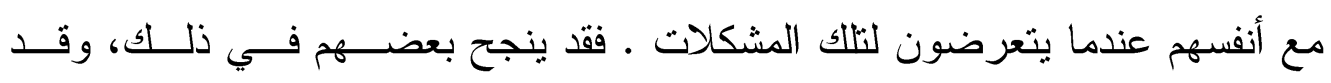

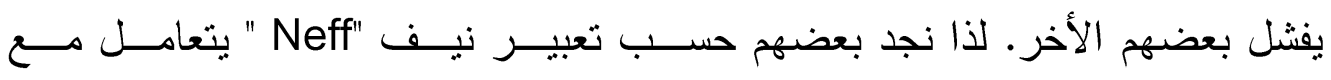

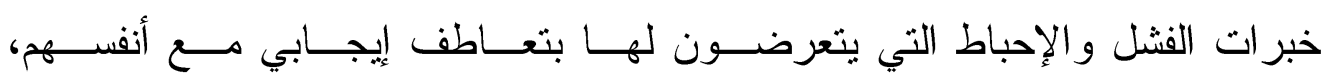

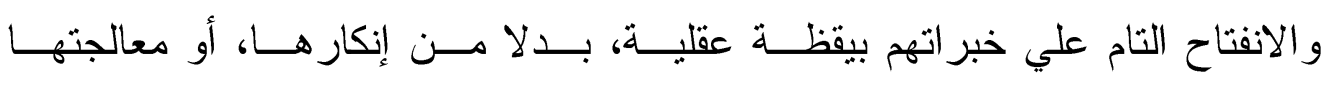

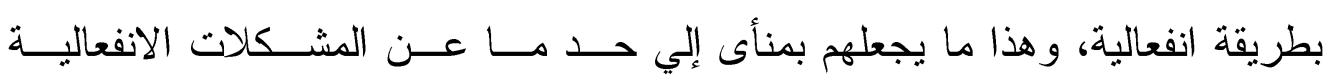
التي قد تصيب الأفر اد الآخرين الذين لــيس لــديهم القـدرة علــي التصـــالح مــع 


\section{$1 r$}

أنفسهم و الر أفة بها، وخصوصـا الذين يفشــلون فـــي مواجهــة خبــر اتهم المؤلمـــة؛ فهم نتيجة لذلك يعيشون حالة من القلق و الاكتئـاب، و التــوتز وتتســـ شخصــيتهم بالجمود الفكري، و العزلة الاجتماعية، ونقد الذات .

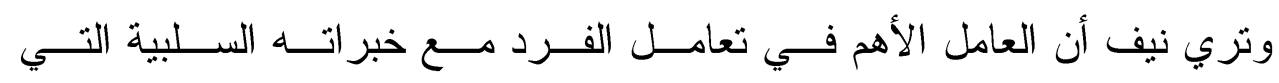

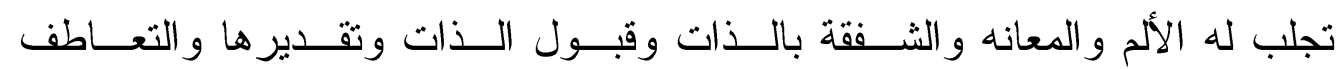

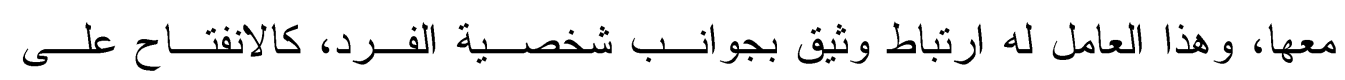

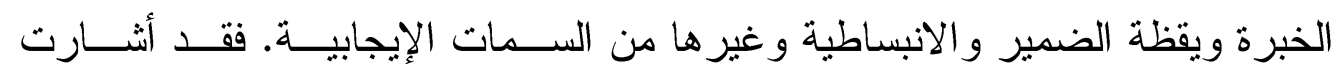

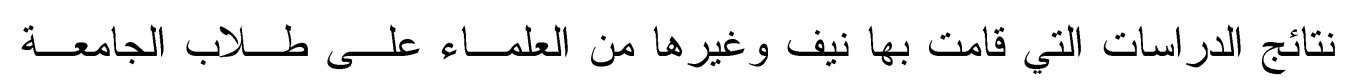

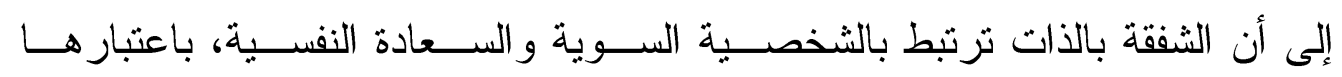

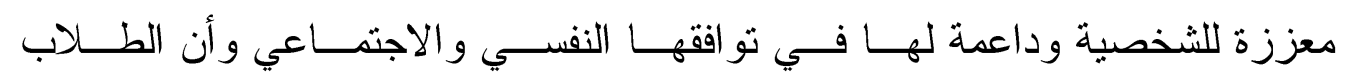

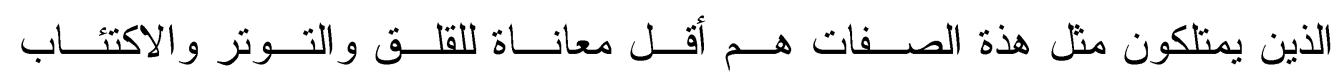

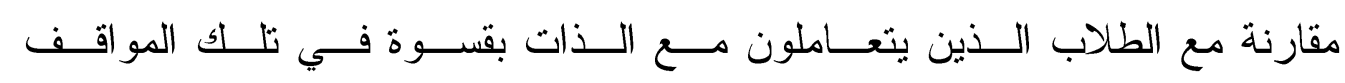
.(Allen\&Knight, 2005,239-262)

كمـــا أثـــارت در اســة (Leary, et al.2007) أن طــلاب الجامعــة الــذين

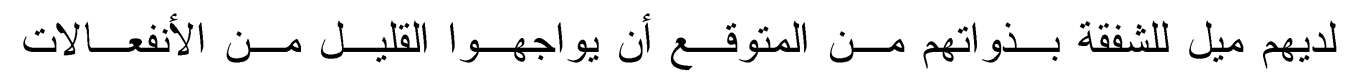

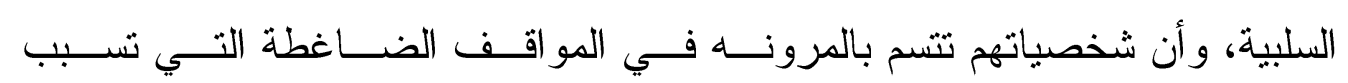

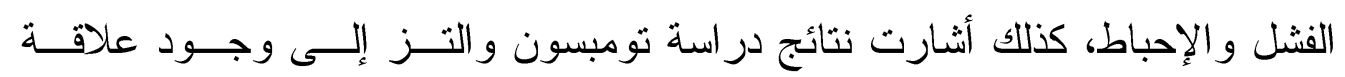

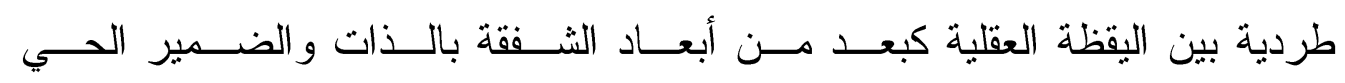
و المقبولية الاجتماعية (1885 -1875). وتشير نتائج الدراسات التي أجريت علي الثفقة بالـــات إلـــي وجـــود علاقــة

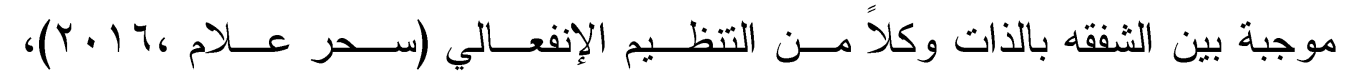
الإقــدام علـي المخــاطرة (Holtham \& Murray,2014)، ســمات الشخصــية

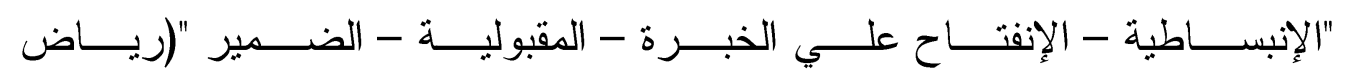

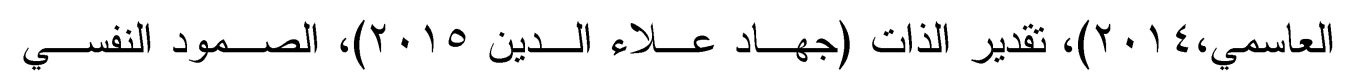
و Neff\&Mc)

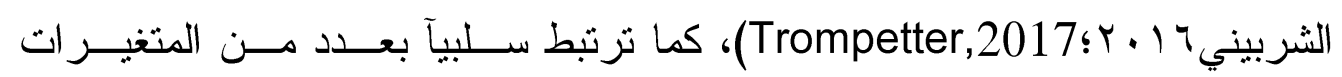




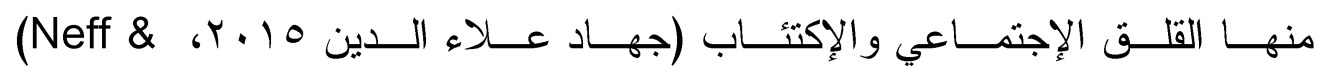
.(McGehee, 2010

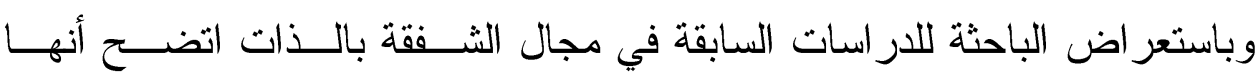

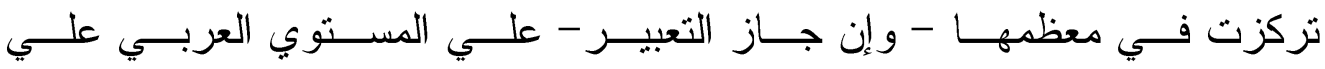

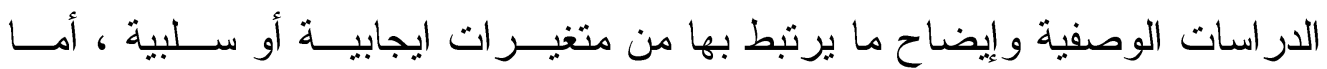

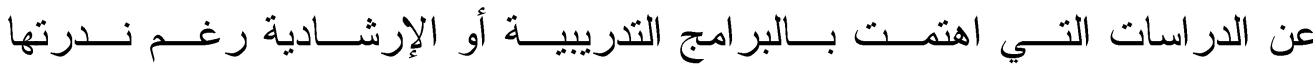

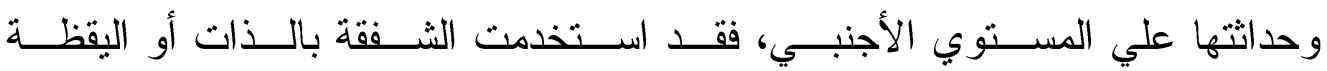

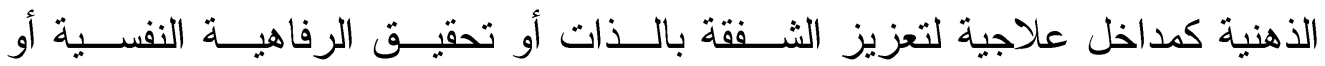

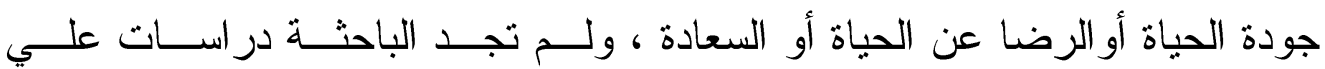

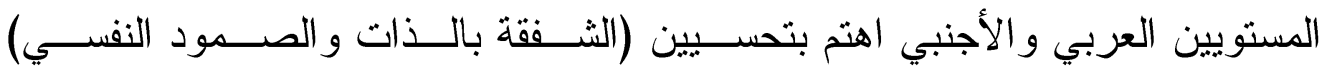

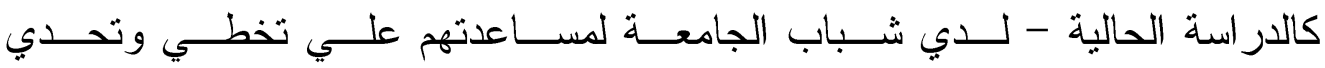

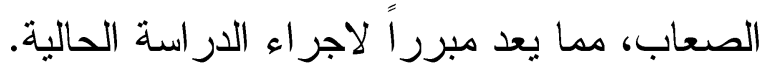

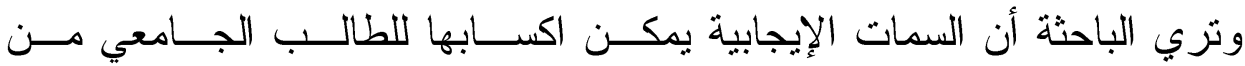

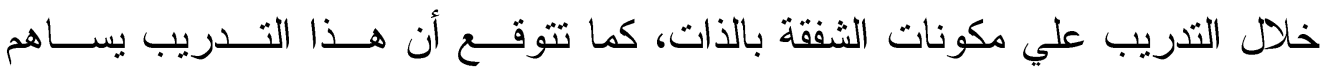

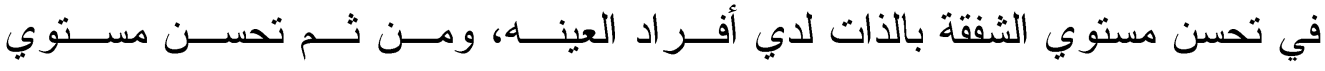

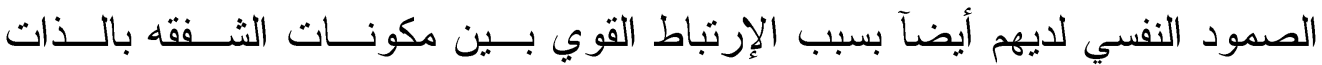
و الصمود النفسي. وبناء علي ذلك فان مشكلة الاراسة تتحدد في الإجابــة عـــي التســاؤل الــرئيس

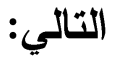
- - ما فعالية برنامج ارشادي في تتمية الثفقة بالـــات وتحســن الصــمود النفسـي

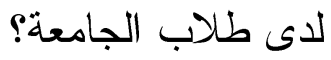

ويتفرع عن هذا التساؤل الرئيس مجموعة التساؤلات الفرعية التالية :

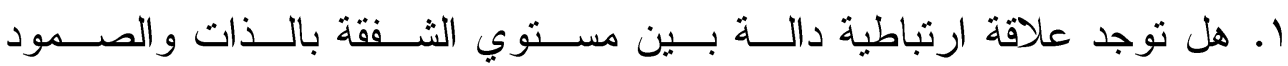

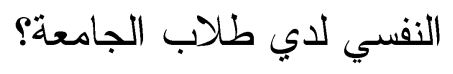

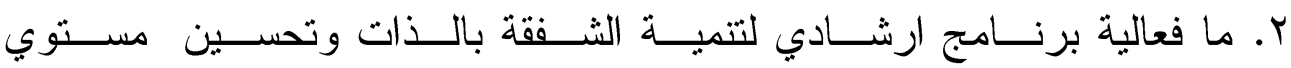

$$
\text { الصمود النفسي لاي طلاب الجامعة؟ برنج }
$$


r. هل تستمر فعالية البرنامج الارشــادي- إن وجــدت - فــي تتميــة (الثـفقة

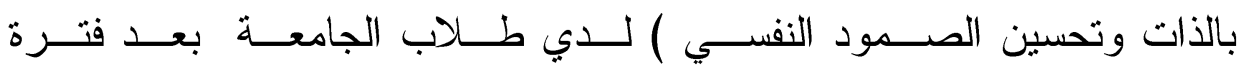
المتابعة و التي استغرقت شهرين بعد انتهاء البرنامج ؟ باء أهداف الار استة تتمثل أهداف الدر اسة الحالية في : ا. التحقق من وجود علاقة ارتباطية بــين مســتوي الشــقة بالــذات و الصــمود

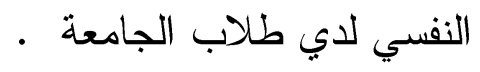
r. التحقق من فعالية برنامج ارشادي علي مكونات الثــفقة بالــذات فــي تحســين مستوي (الشفقة بالذات و الصمود النفسي) لدي طلاب الجامعة.

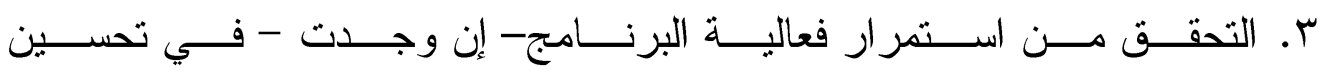

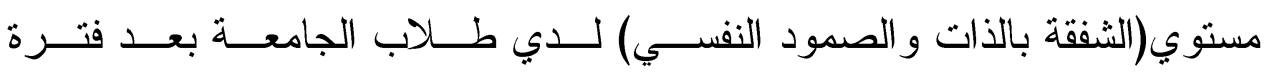
المتابعة و التي استغرقت شهرين بعد انتهاء البرنامج. أهمية الار اسة

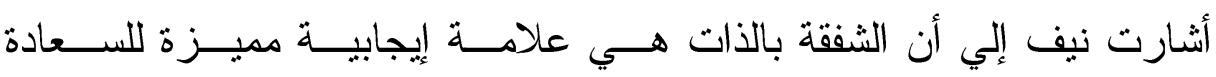

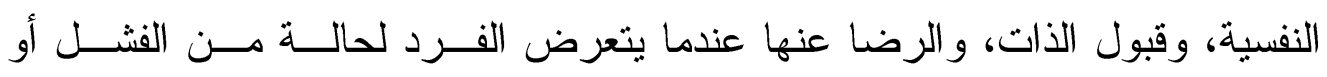

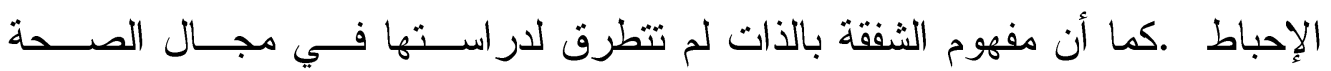

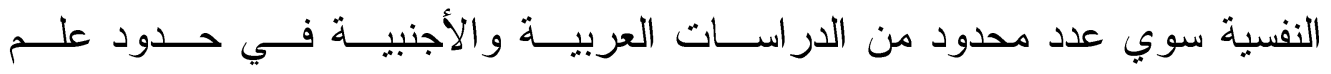

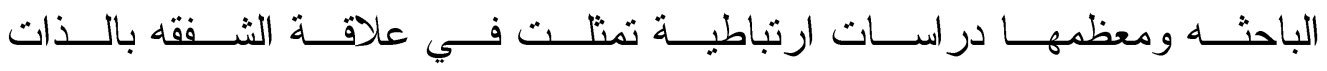

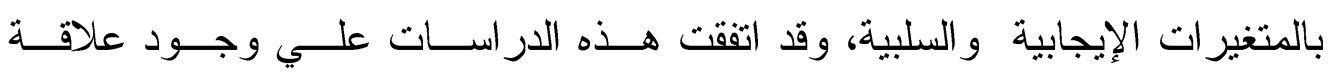
ايجابية بالسمات الإيجابية للشخصــية، وعلاقــة سـلبية مـــع المتغيــرات الســلبية

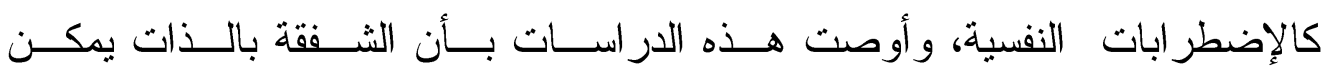

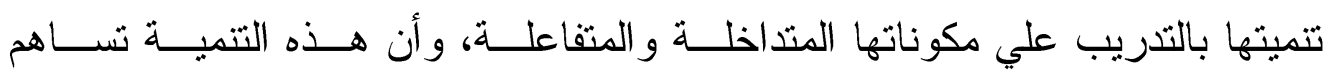
في ترسيخ وتحسين السمات الإيجابيــة للشخصــية كالســعادة و الرفاهيــة النفسـية

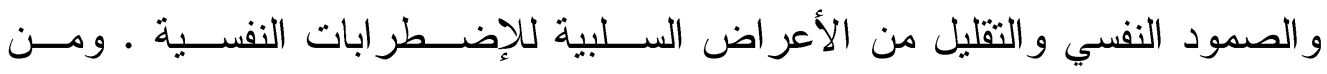
هنا جاءت أهمية الدر اسة الحالية في النقاط التاليه : 


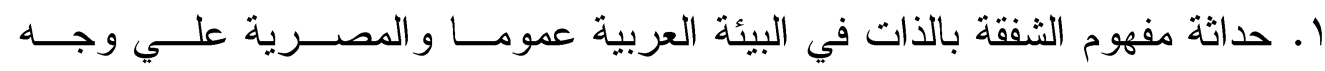

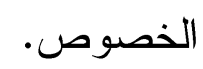

Y. تكتسب الدراسة أهميتها مــن تتاولهـــا لمتغيـرى الثــفقة بالــذات و الصــمود

النفسي كأحد المتغيرات الإيجابية المهمه فـي بنـــاء الصــــة النفسـية للفــرد

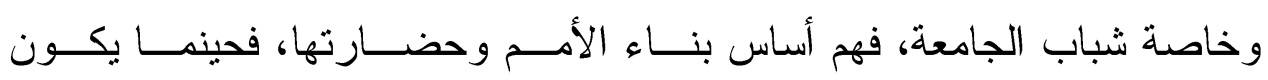

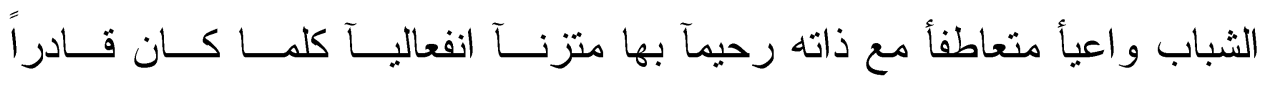
علي إدارة حياته وتحقيق النجاح في حياته المستقبلية.

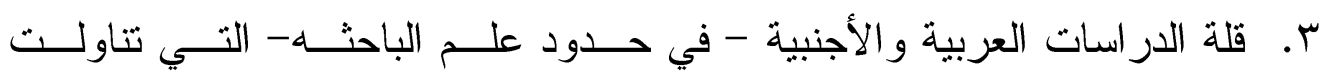

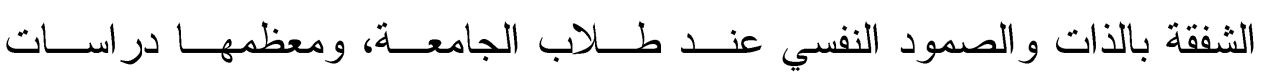

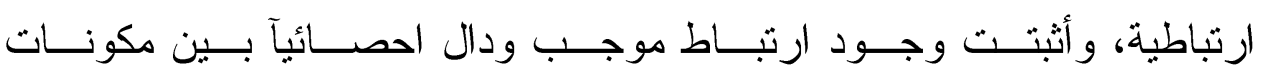

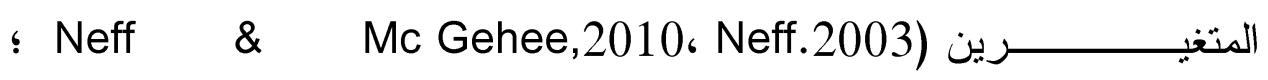
Kurilova,2013 .(al, 2017 , ع. تصميم برنامج تذريبي مقدم لطلاب الجامعــهـ قــد يســهم فــي تتميــة الثــفقة بالذات وتحسين الصمود النفسي لديهم، ومن ثم تحسـين الخصــائص النفسـية

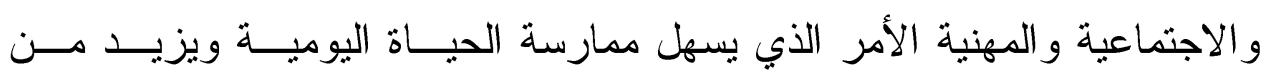
تفاعلهم الإيجابي مع الآخرين.

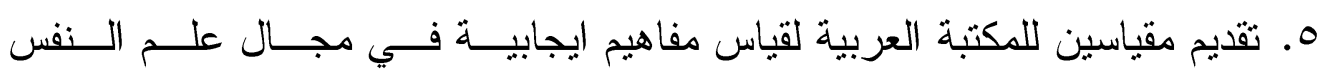

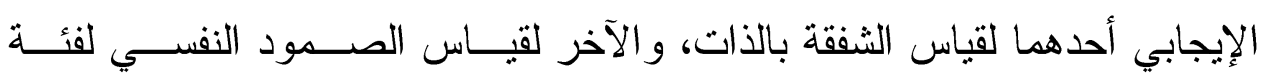
الشباب، حيث يمكن استخدامها في اجر اء المزيـــ مــن الدراســات المســتقبلية لاي عينات أخري.

المصطلحات الإجرائية للار اسة : المينة Counselling Program : البرنامج الارشادي الإنزال هو برنامج مخطط ومنظم في ضوء أسـس علميــة لتقــديم الخــدمات الارشــادية

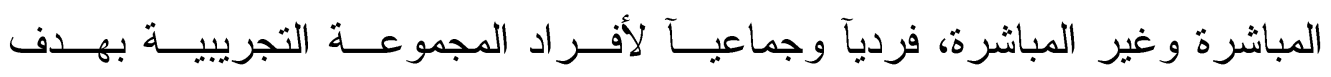




\section{IY}

تحسين مستوي الشفقة بالذات و الصمود النفسي لديهم مــن خــلال الإعتمــاد علـي عدد من الفنيات المشتقه من مداخل علاجية مثتو عه.

Self- compassion : الثفقة بالذات من -

تعرف الشفقة بالذات وفق منظور نيف بأنها " اتجاه إيجــــي نحـــو الــذات فــي

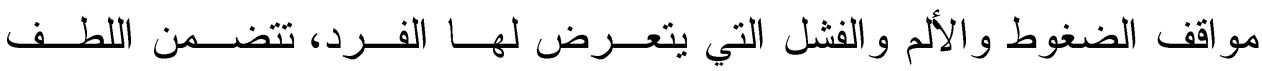
بالذات، و عدم الانتقاد الثديد لها، وفهم خبر اتهـــا كجـزءء مــن الخبــرة التـي

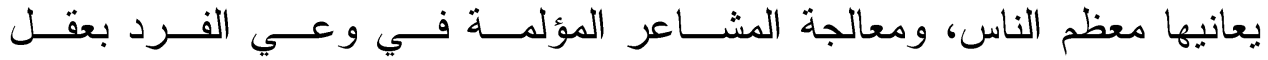

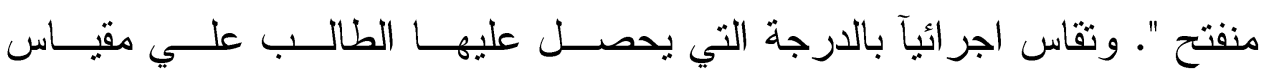
الثفقة بالذات المستخدم في الدر اسة (تعريب الباحثة ).

\section{Psychological Resilience : الصمود النفسي -}

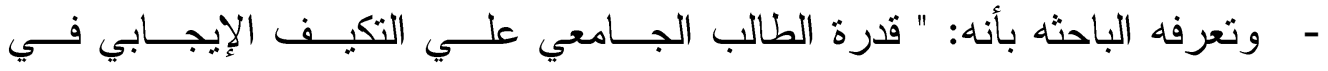

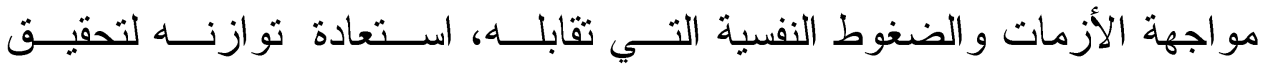
أهدافه، من خلال امتلاكه مهار ات الكفـــاءة الذاتبـــه، الإجتماعبـــة و الوجدانيــة، المرونه، حل المشكلات، المثابرة وتحقيق الهدف" - ويقاس اجرائياً بالدرجة التي يحصل عليهــا الطالــب علـي مقيــاس الصــمود النفسي المستخدم في الدراسة (اعداد الباحثة). الإطار النظري والار اسـات السابقة

Sellf-Compassion: أولاً الثفقة بالأات إهتمت البحوث و الدر اسـات فــي الفتــرة الاخيــرة بدر اســـة الثــقةة بالــذات، كأحد المتغير ات المهمة والايجابية في شخصية الفرد، ويعـود هــذا المفهـوم إلـي

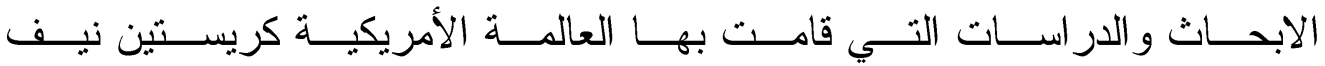
(Neef ,2003a)

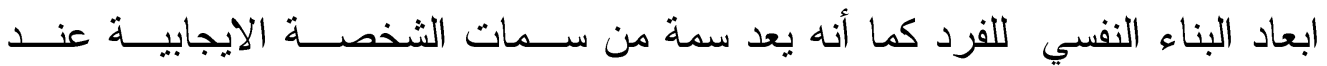

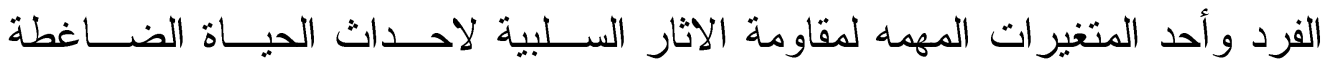
التي يمر بها الفرد، وذلك عندما يعيش الفرد فـي حالــة مــن حــالات الفشــل أو

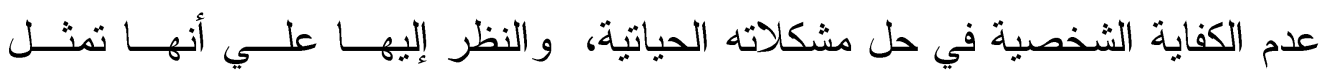




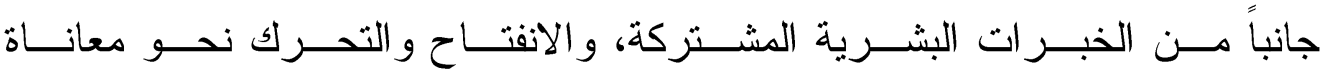

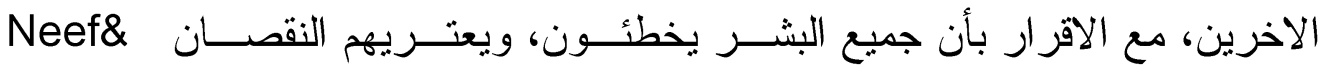
(Costigan :2014)

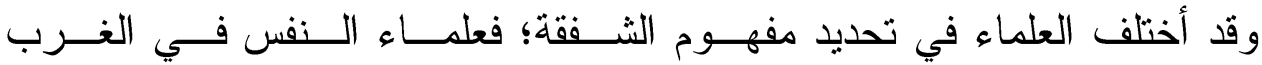

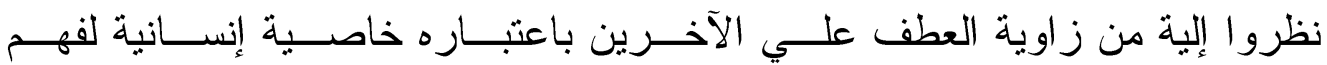

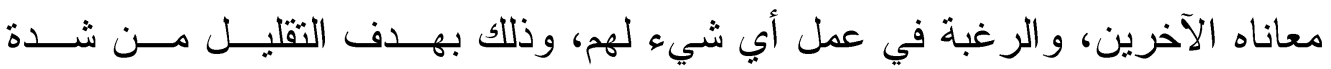

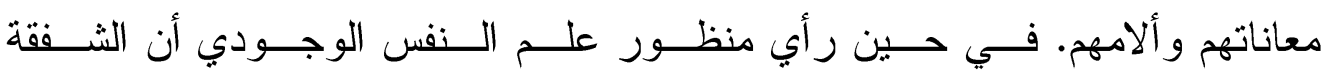

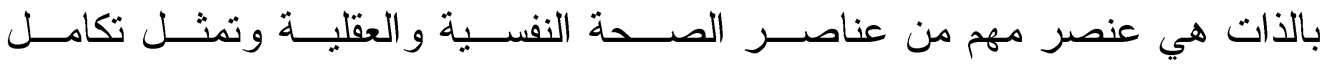

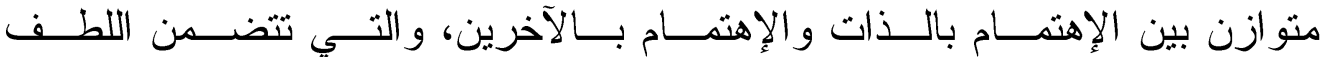

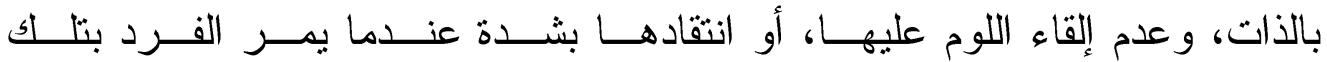

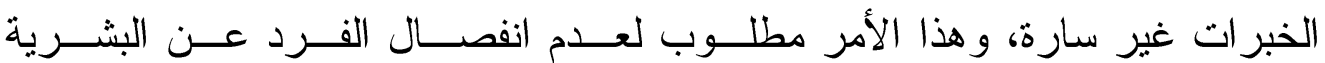

.(Brach.2003a:235)

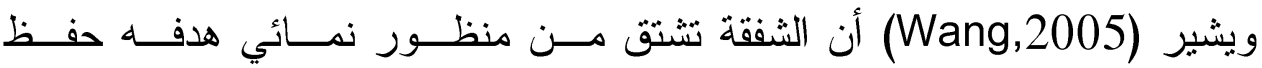

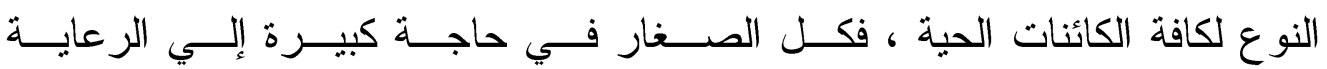

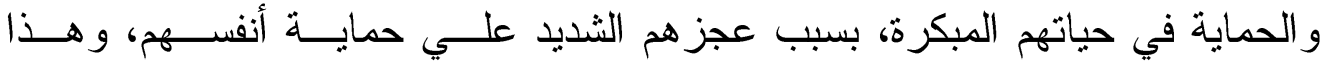

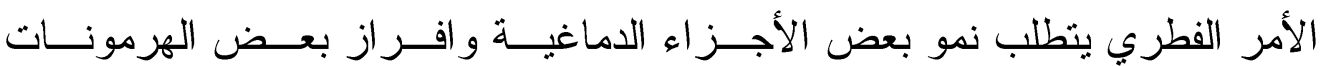

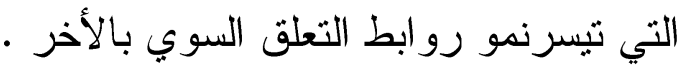

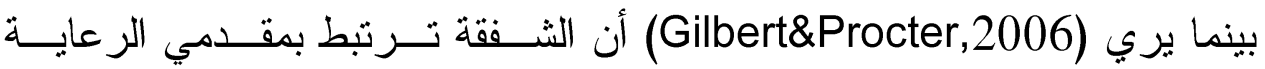

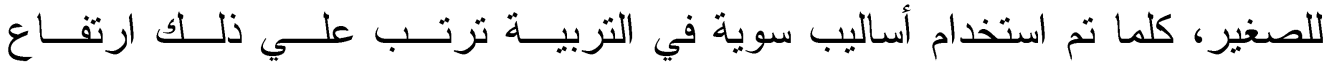

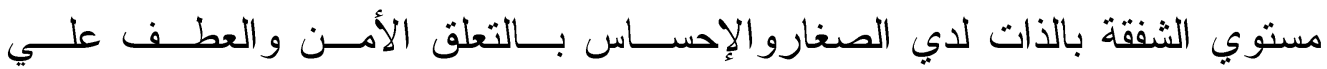

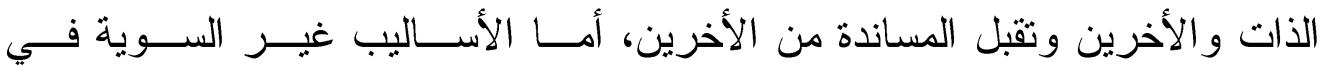
تربية الصغار يترتب عليها مستويات منخفضة من الثفقة بالذات وبالأخر .

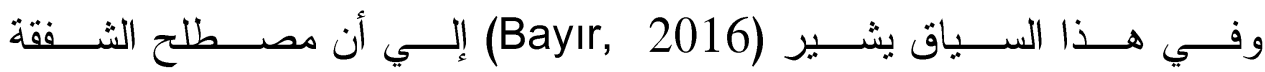

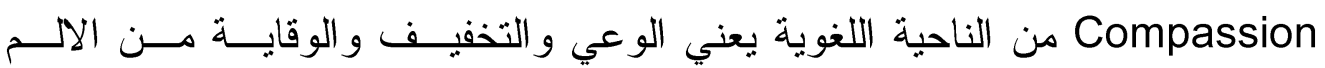
الانفعالي و الذي نتج عن خبر ات الذات و الاخرين. 


\section{Y}

ويضيف (-355 - Goetz ,et al, 2010,351 ) أن الثفقة عبارة عن"خبـرة

عاطفية متمبزة وظيفتها الاساسية تسهيل التعاون ،وحماية الضعفاء، ومساعدة الــذين

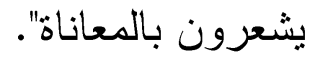

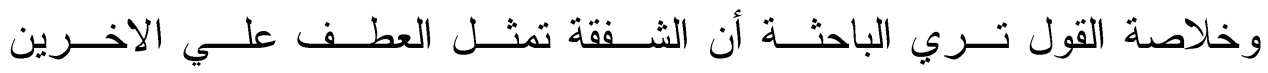

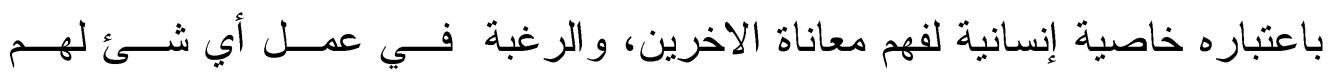

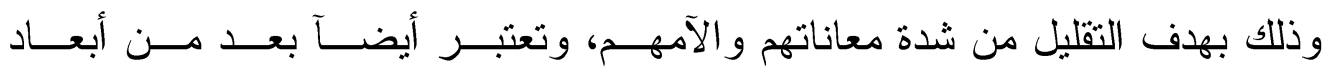

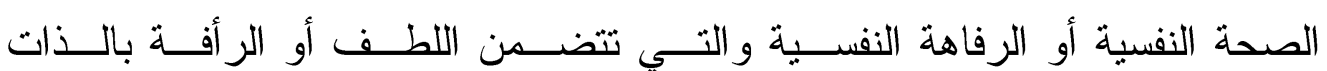

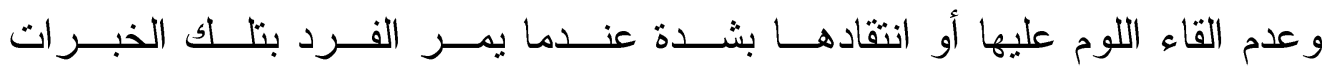

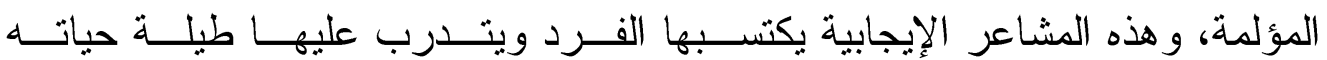

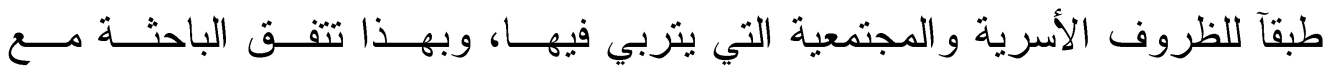

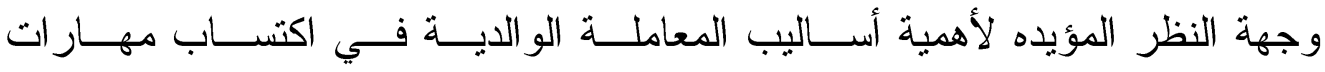

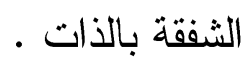

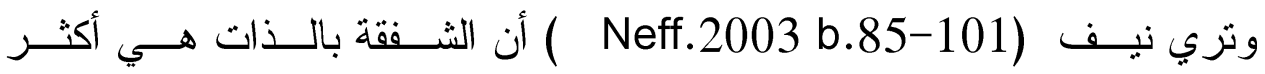

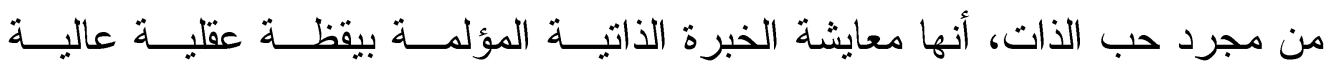
ودون مبالغة انفعالية، فهذا الأسلوب يقوي الثــعور بالســعادة الداخليــة و الســعادة

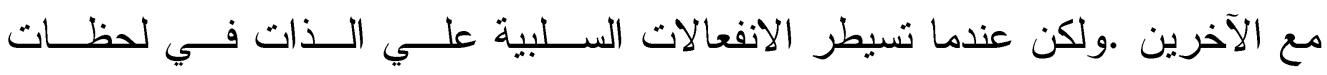

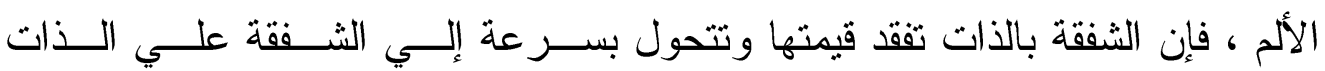
. Self- pity

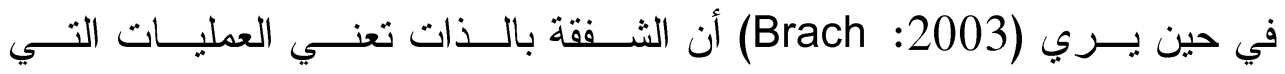
يقوم بها الفرد ليقدم لذاته الدعم المعنوي في لحظات المعاناة. بينما يري كـل مـن (2010 : , Neff.\& McGehee) أن الثــفقة بالـــات

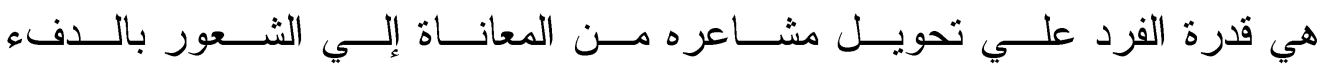

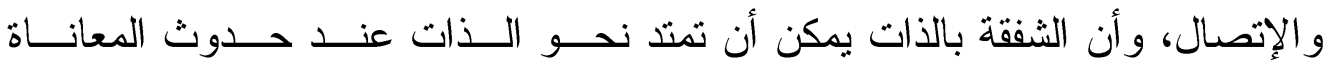

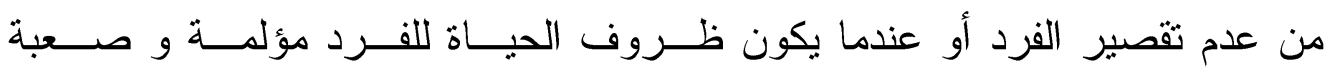

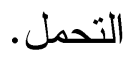




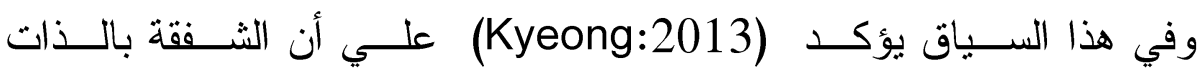

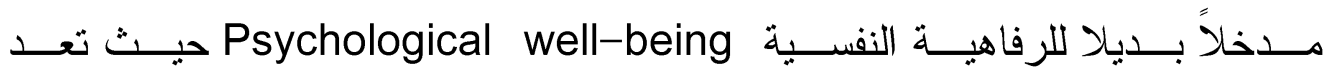

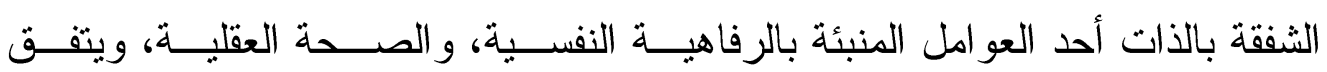

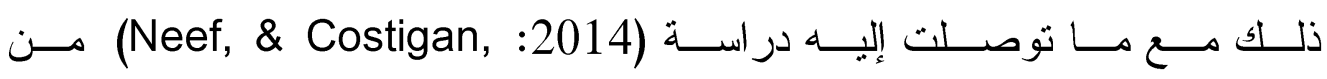

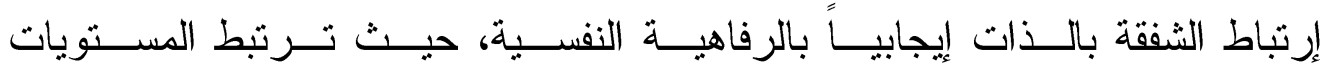

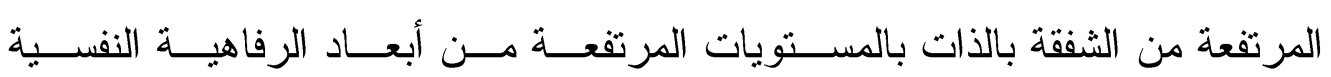
كثقبل الذات و الرضا عن الحياة و المعني من الحباة .

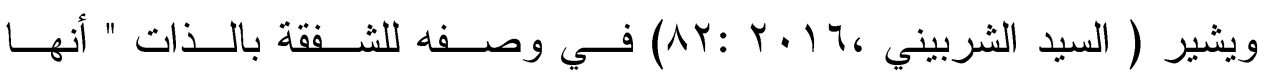

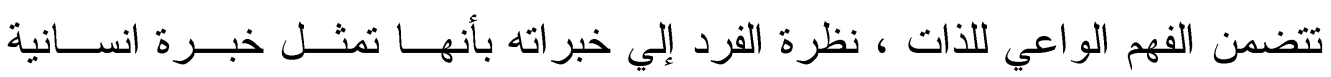

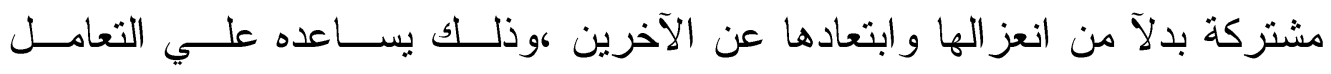

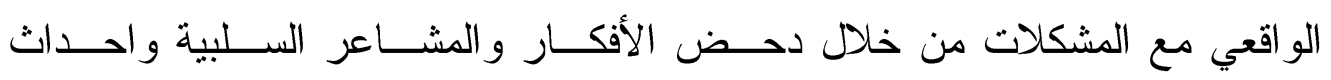

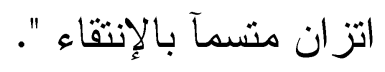

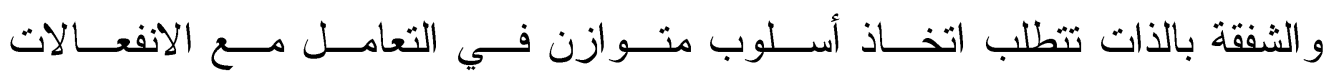

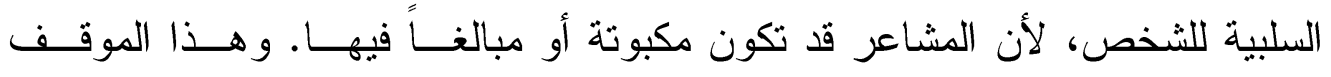

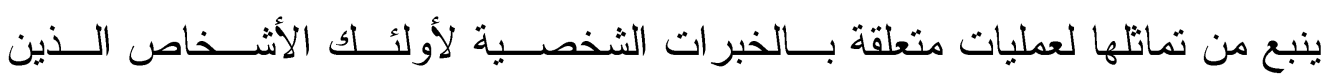

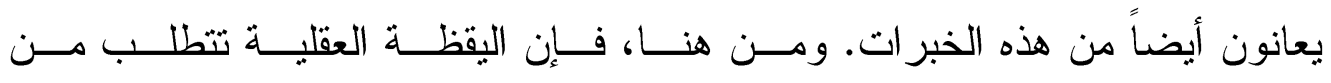

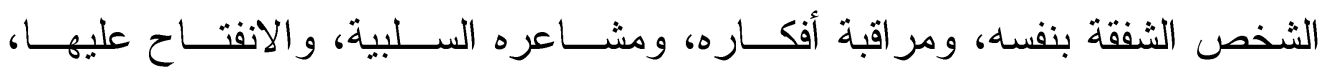

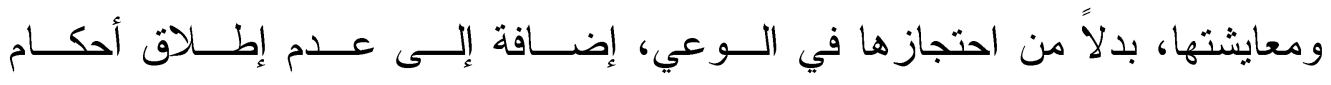

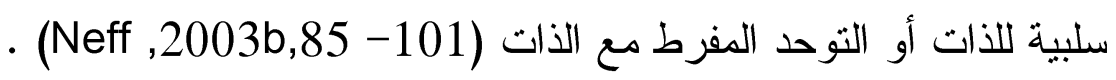
أبعاد الثفقة بالأات

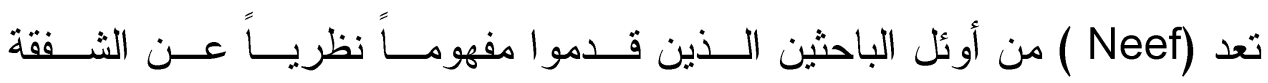

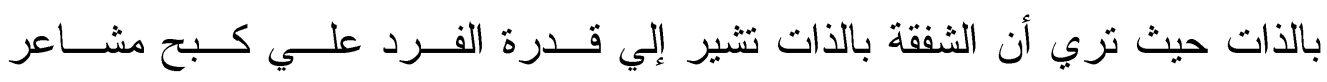

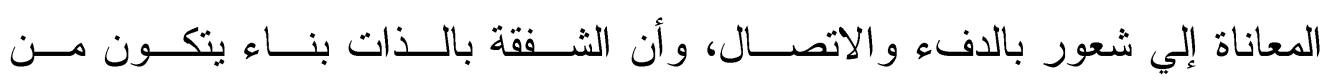
ثلاثة أبعاد أساسية هي (Neef \& Dahm,2015). 


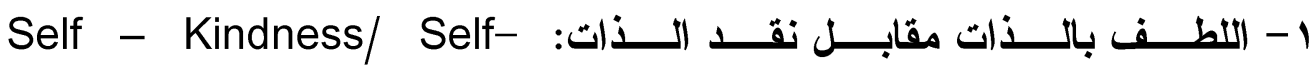
Judgment

ويعبر هذا البعد عن فهم وتدعيم الفرد لنفسه في مو اقــف عــدم الكفــــاءة الذاتيـــة

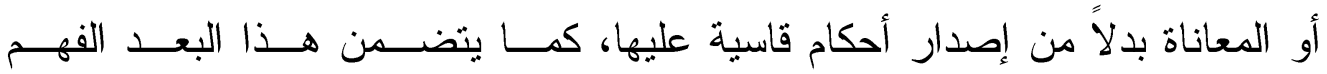

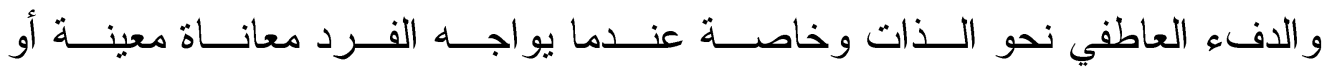

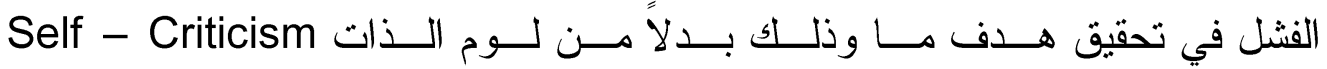

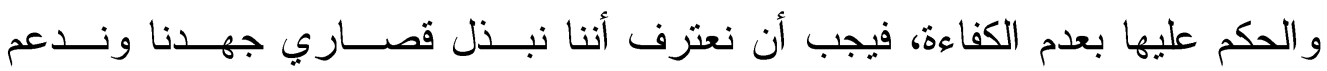

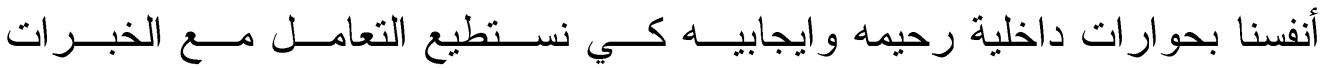

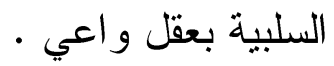

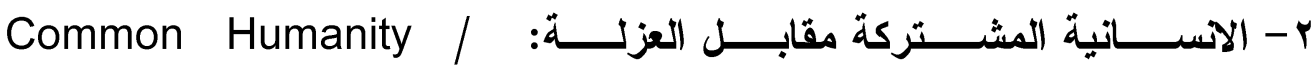
Isolation

ويشير هذا البعد إلي رؤية الفــرد لخبراتــه الخاصــة كجـزءء مـــن الخبـرة

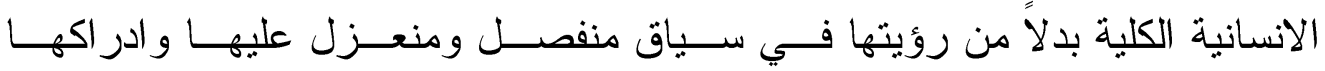

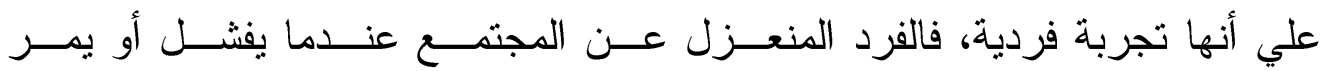

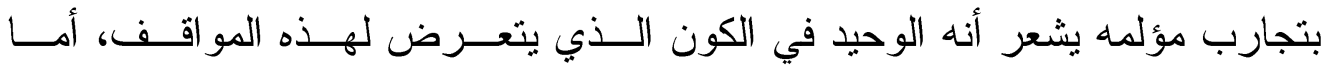

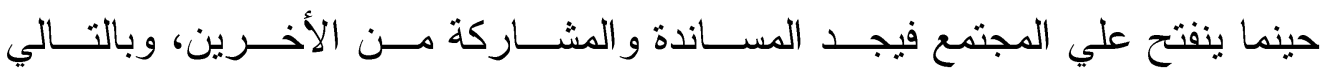

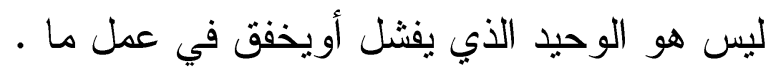

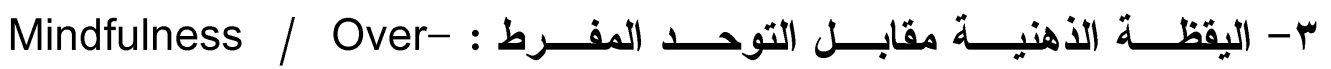
identification

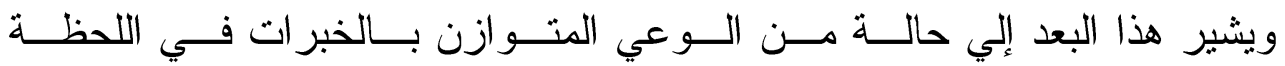

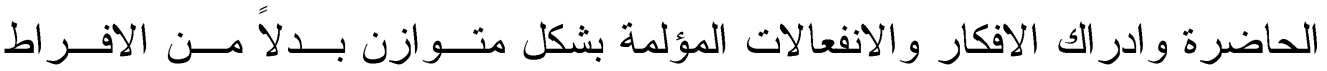

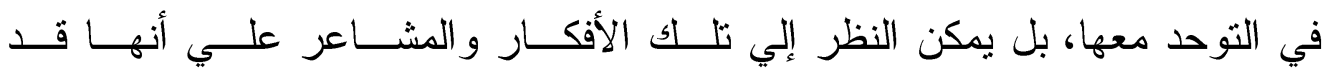
تساعدنا في التخلص من الضغوط و المشكلات .

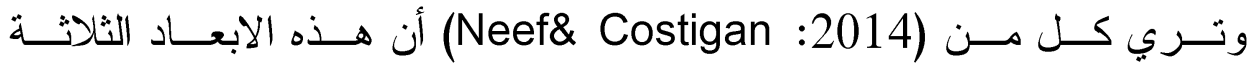

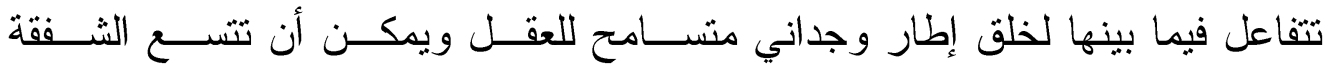

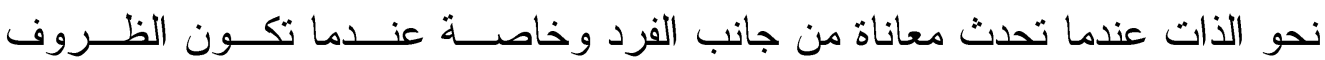


الخارجية من الحباة مؤلمة أو صعبة و لايمكن احتمالهــا ، وعنــدما تتثـــأ المعانـــاة

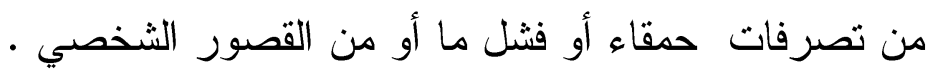

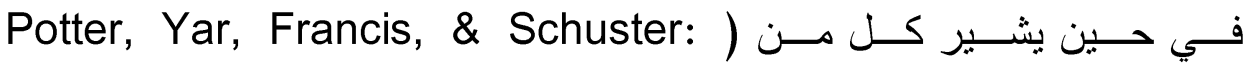

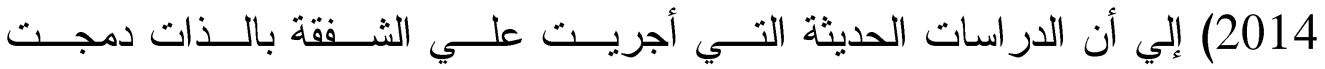
الابعاد التي قدمتها Neef في بعدين رئيسين هما :

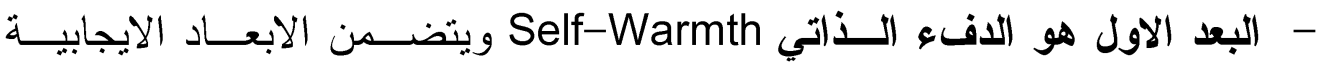

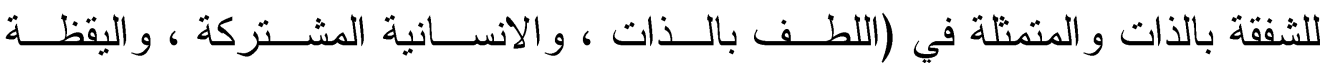

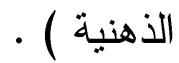

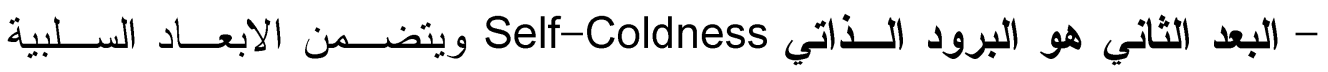
و المتمثلة في (نقد الذات ، العزلة ، التوحد المفرط ) .

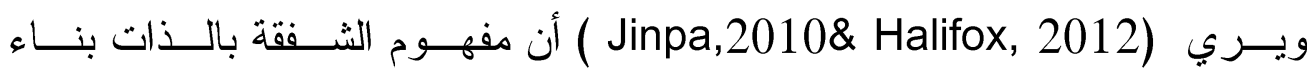

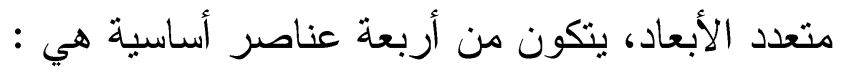

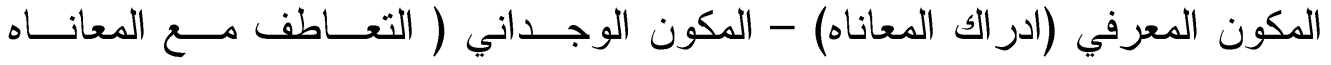

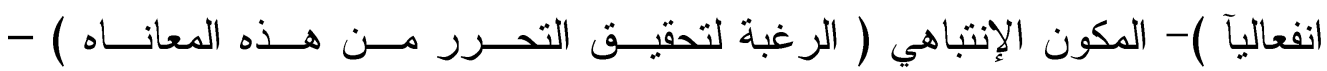

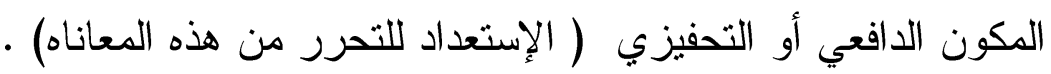

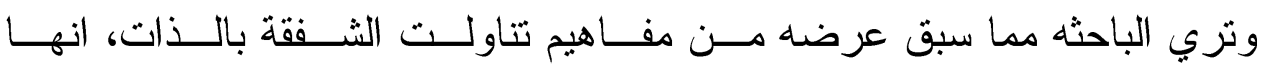

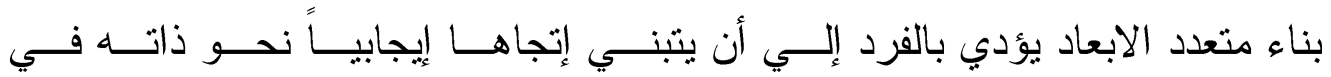

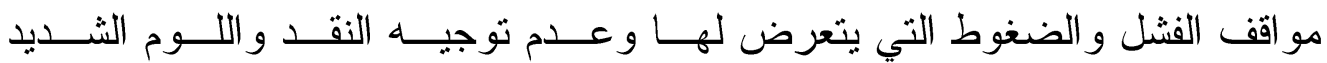

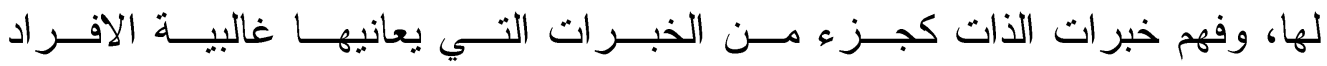

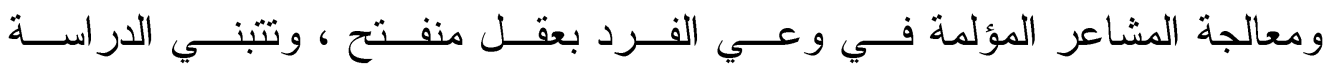

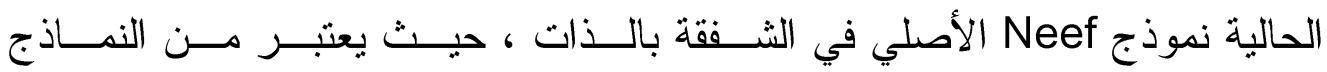

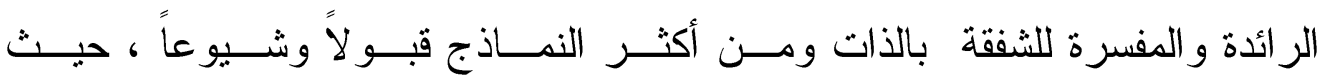

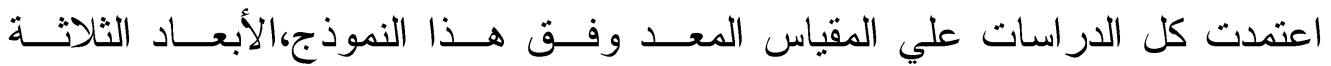

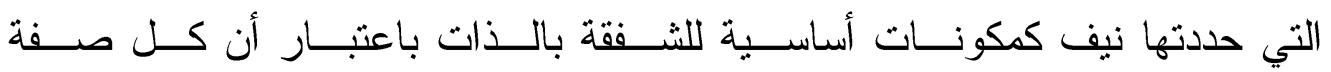

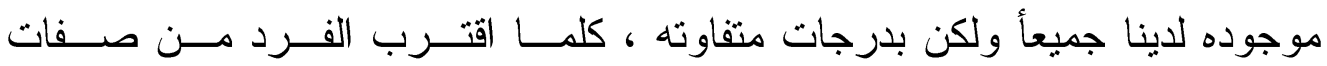

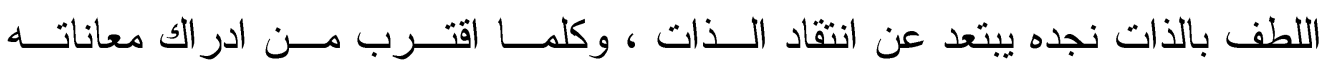




\section{$1 \%$.}

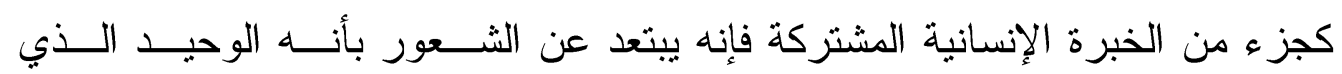

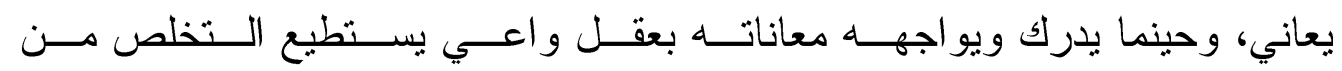

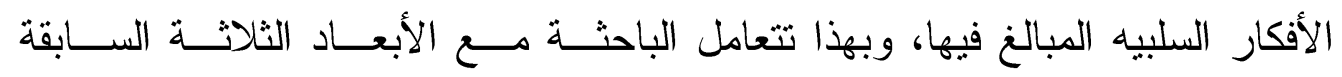

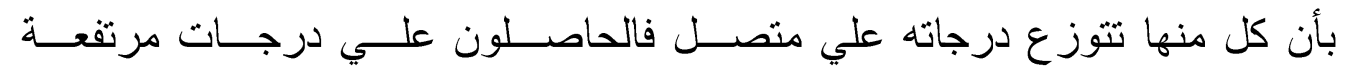

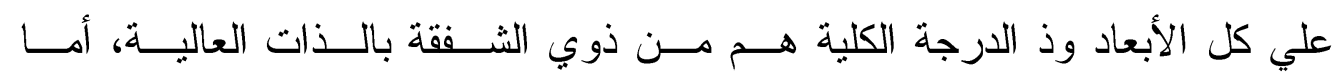

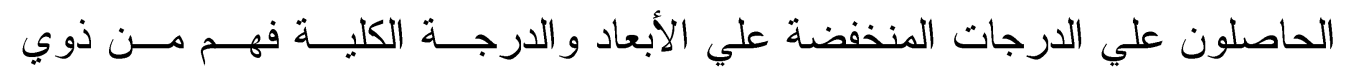

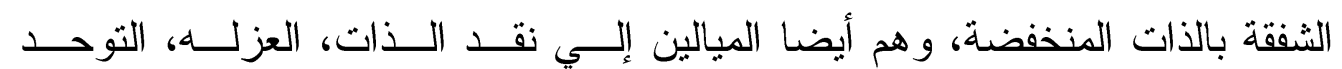
المفرط دراسات تناولت الثقفة بالذات.

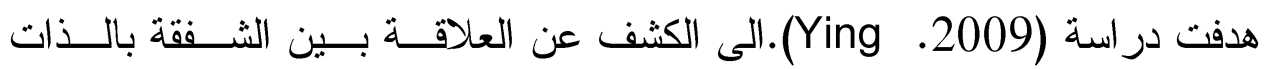

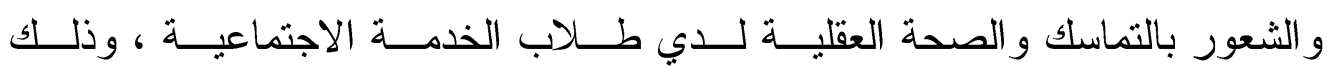

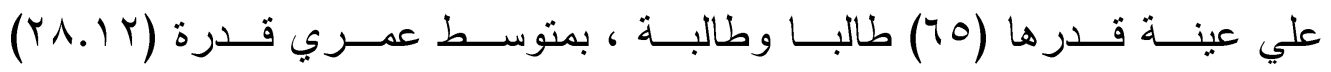

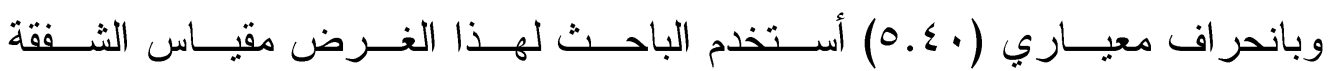

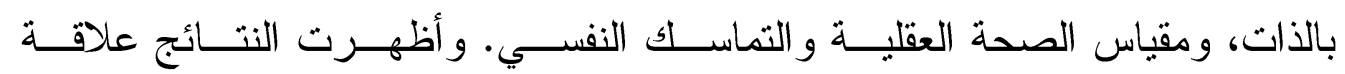

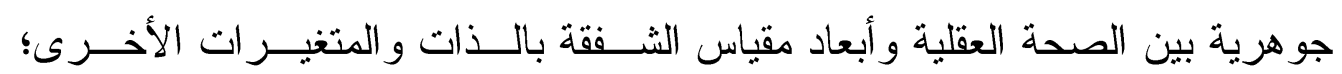

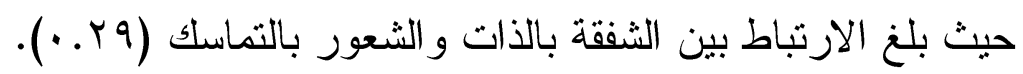

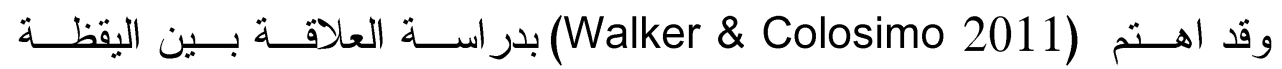

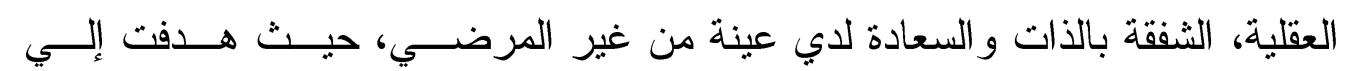

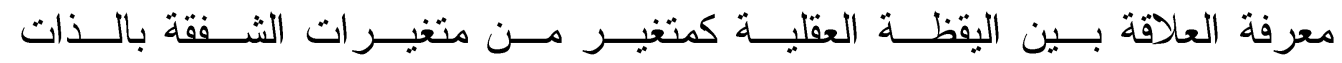

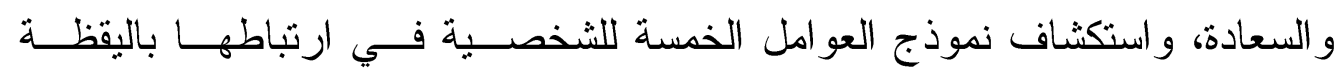

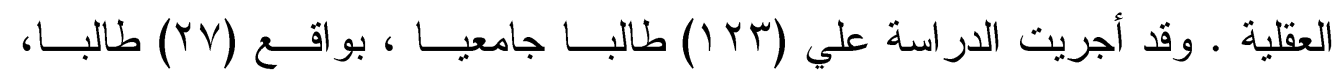

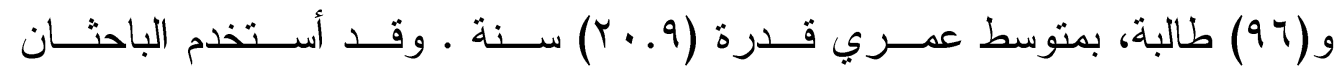

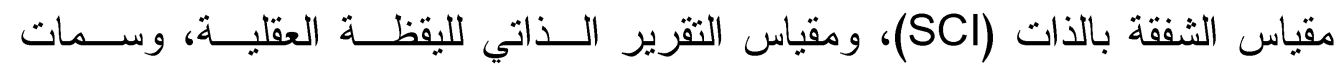

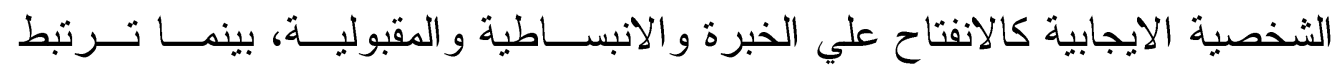

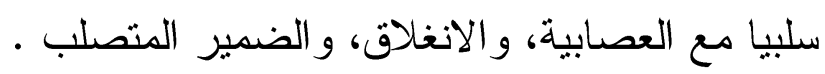


أما دراسة (2013: Kyeong) فقد هدفت إلي التحقـق مــن أن الثــفقة بالـــات

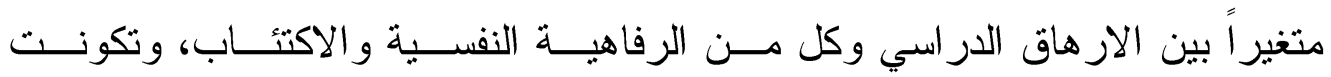

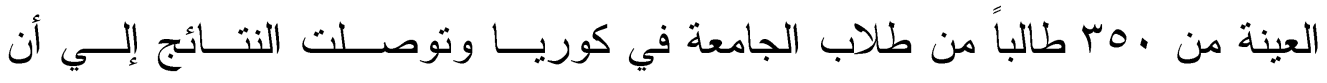

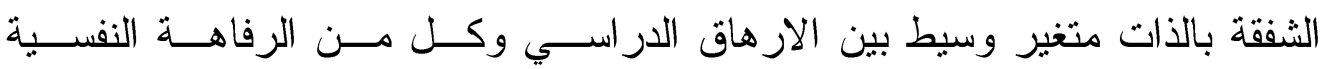
و الاكتئاب .

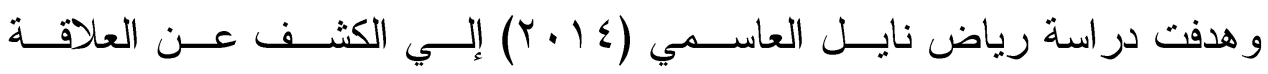

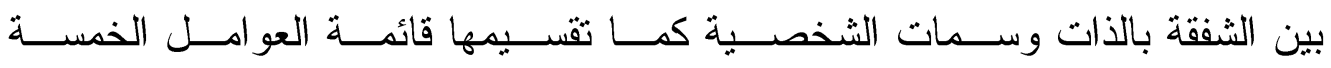

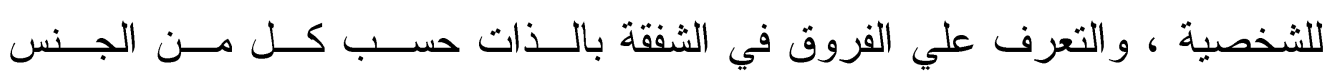

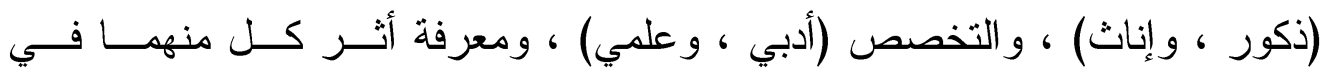

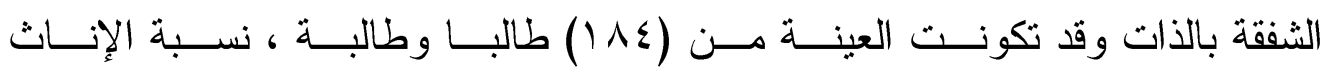

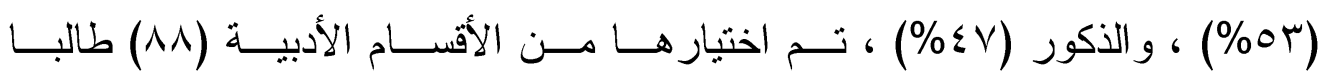

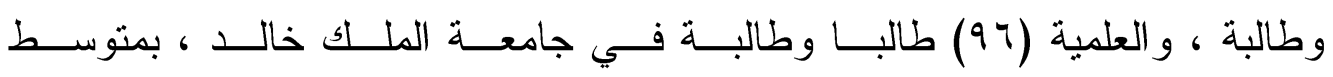

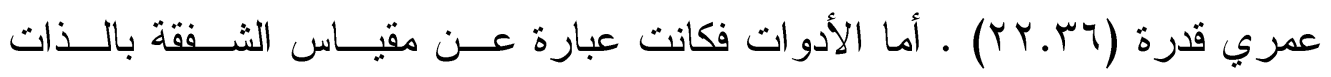

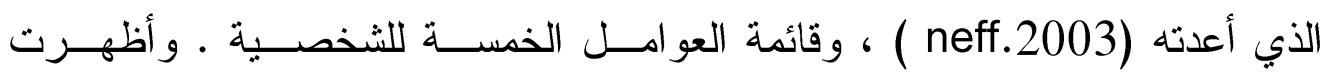

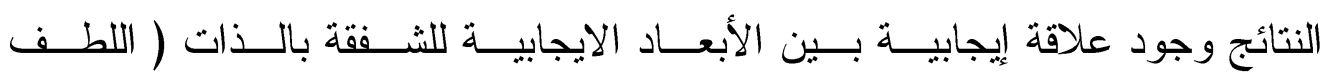

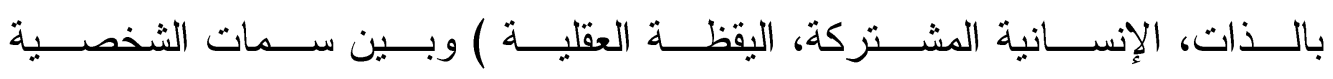

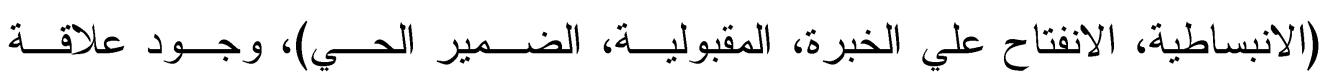

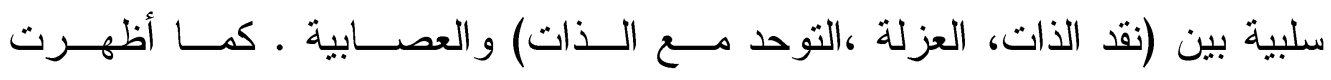

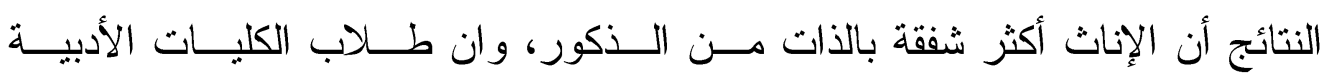

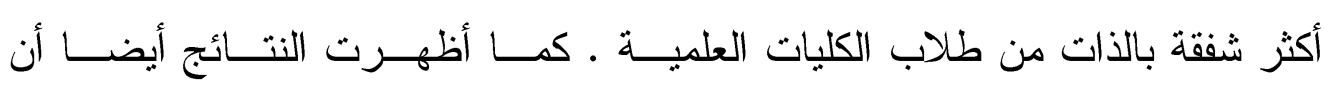
هناك تفاعلا دالا بين الجنس و التخصص و الثفقة بالذات.

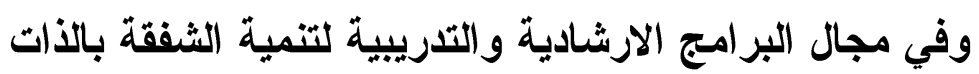

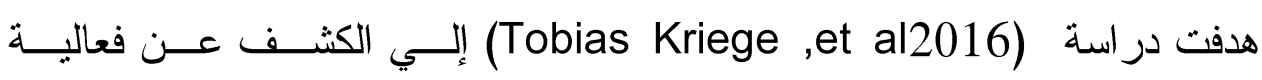

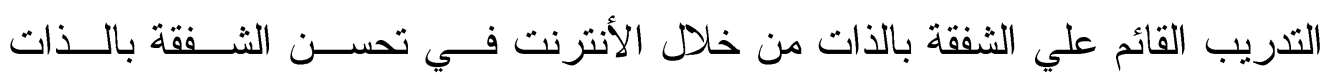

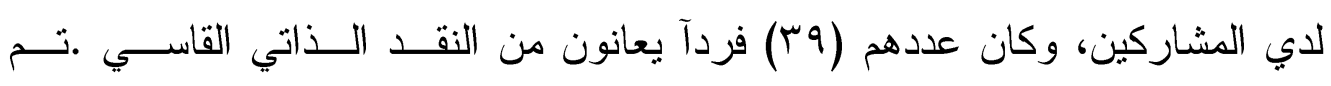

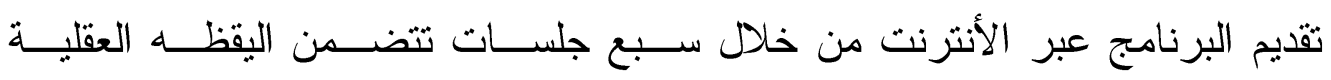




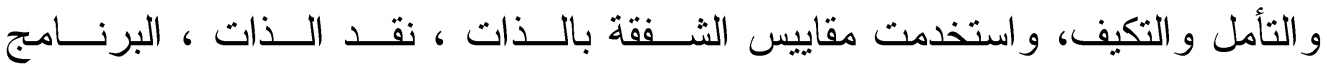

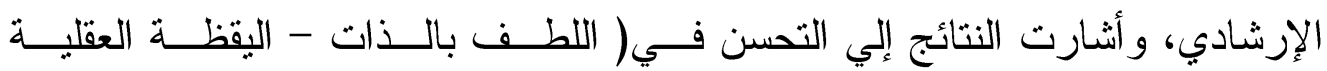

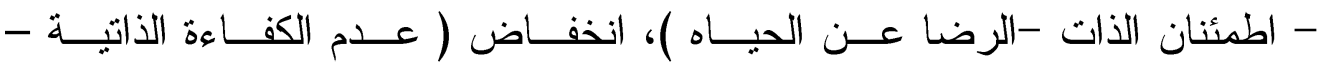
كر اهية الذات - الشعور بالخوف ).

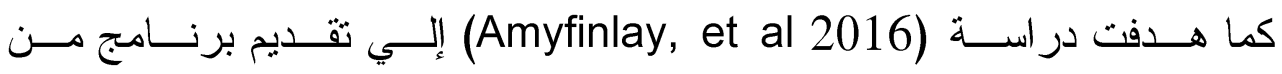

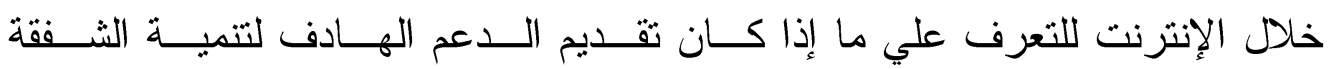

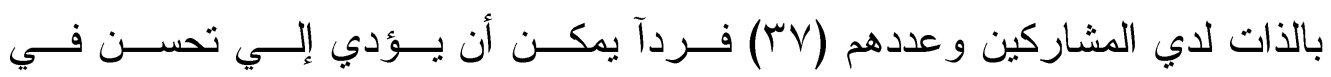

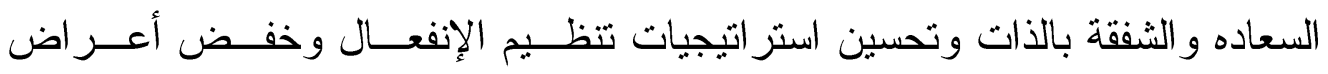

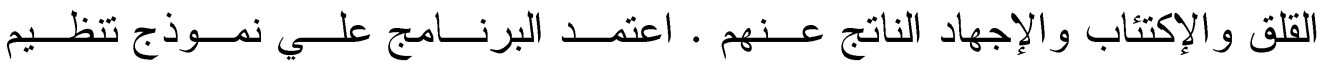

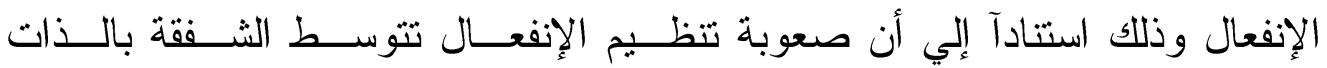

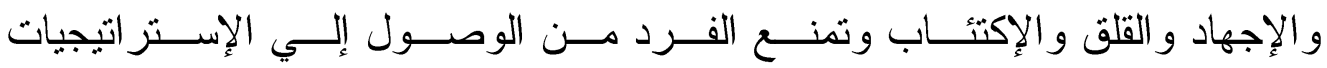

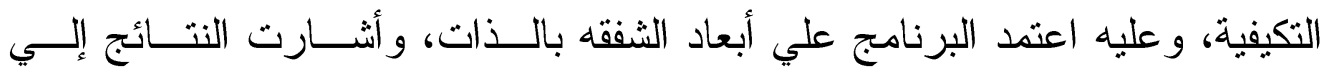

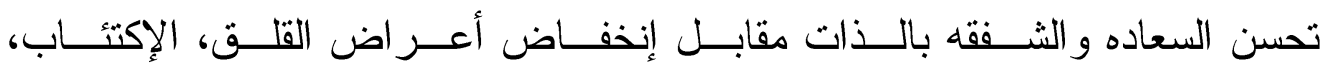
الإجهاد ، صعوبة تنظيم الإنفعال .

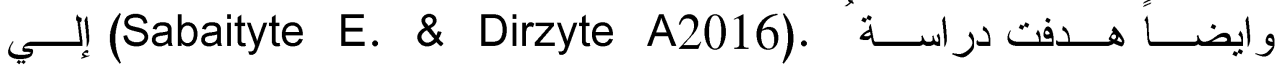

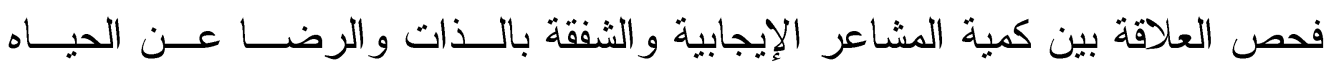
للدي الثباب العاطلين ، و اكتثاف الفرق بين كميــة الششــاعر الإيجابيــة و الثــفقة

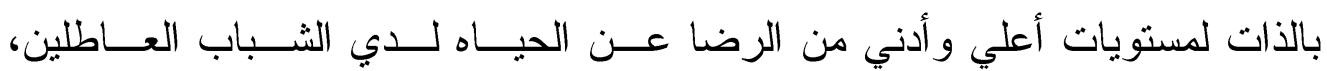

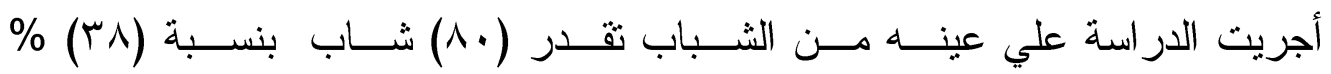

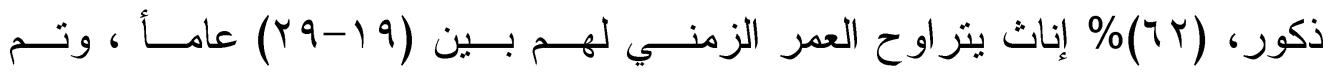

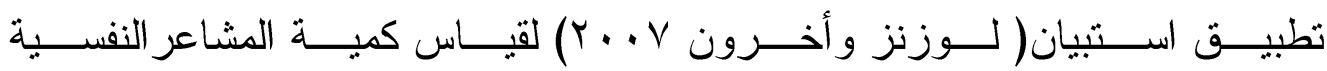

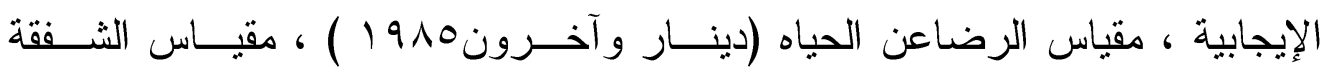

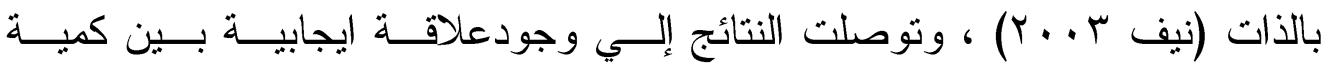

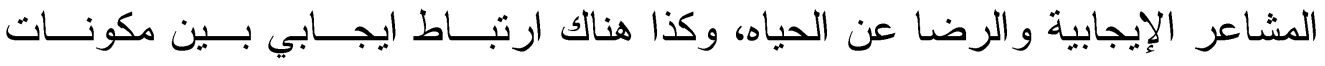

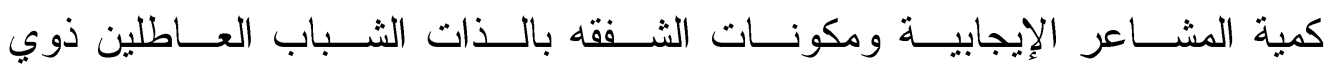
المستويات العليا من الرضـا عن الحياه يمتلكون مشـــاعر ايجاييـهـه وعاطفــة تجـــاه 


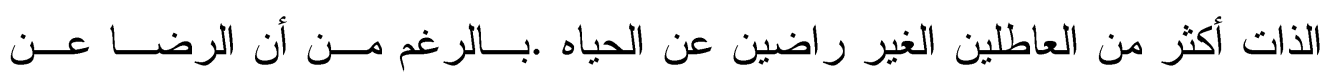

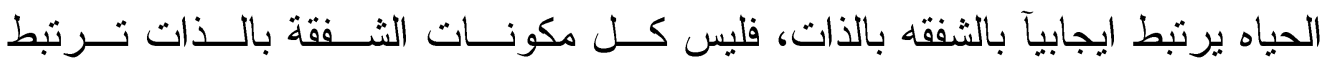

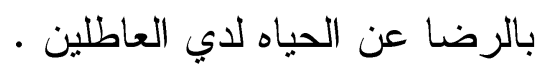

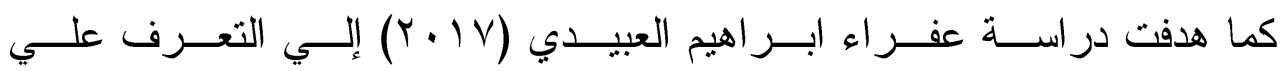

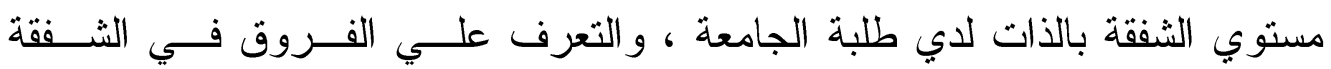

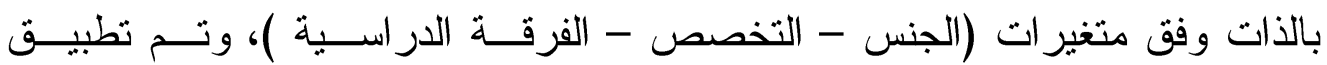

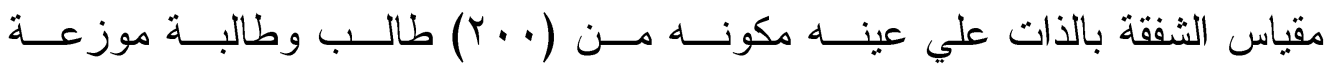

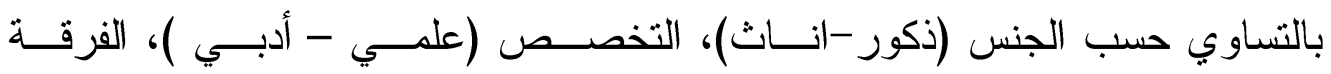

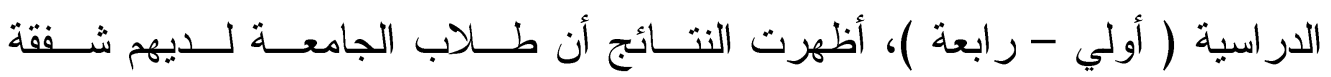

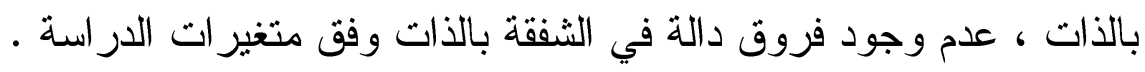

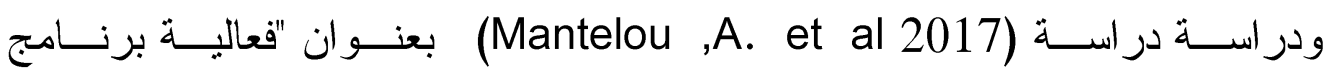

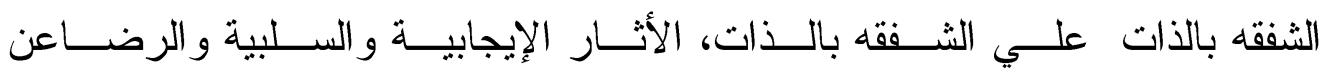

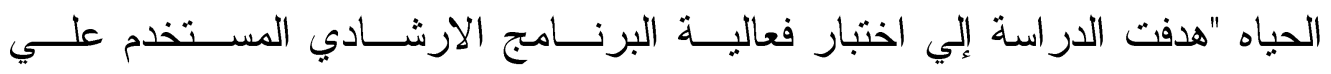

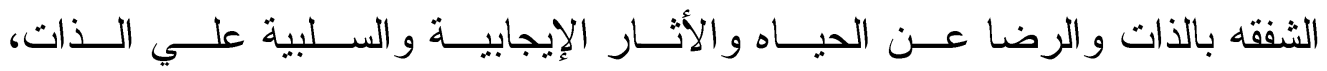

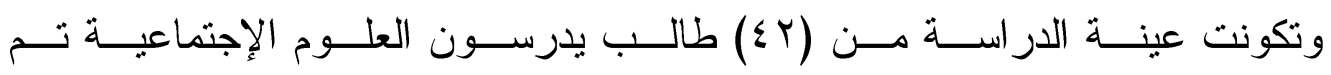

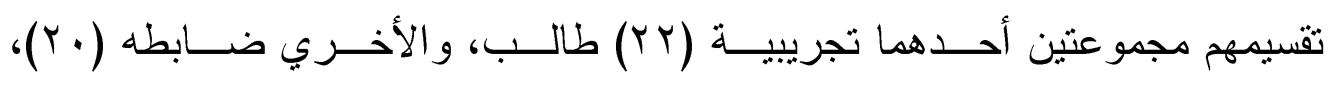

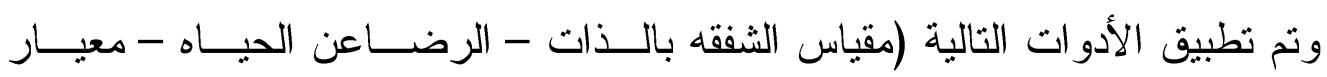

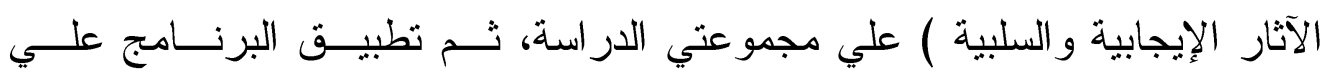

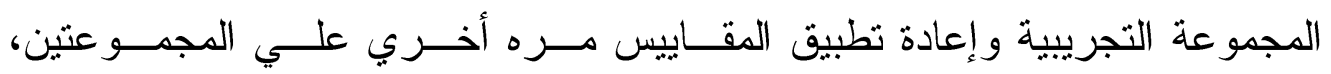

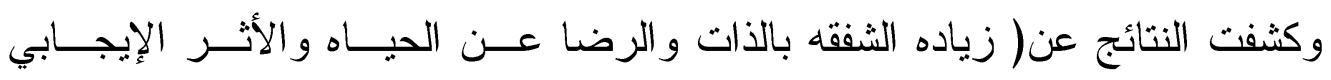

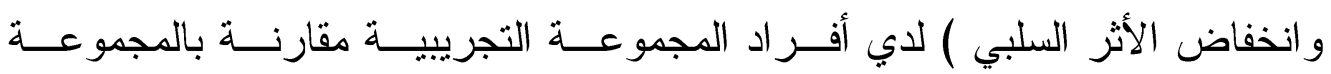

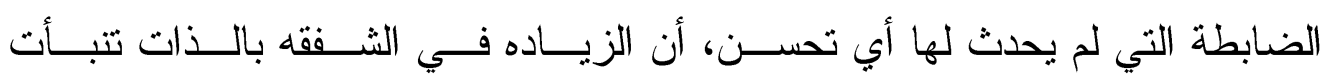

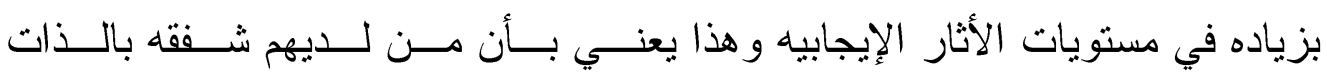

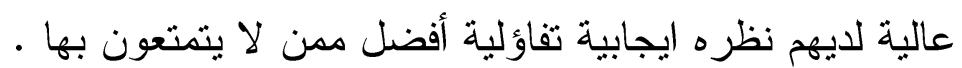

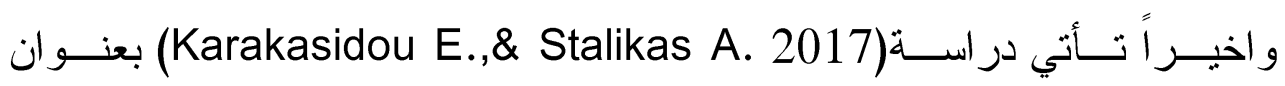

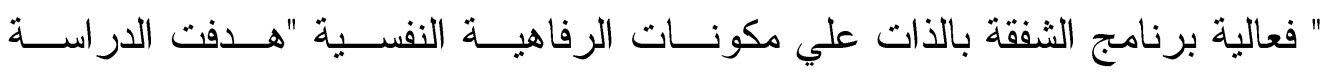




\section{Irs}

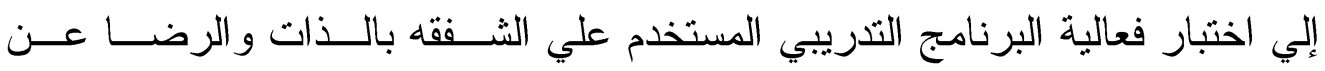

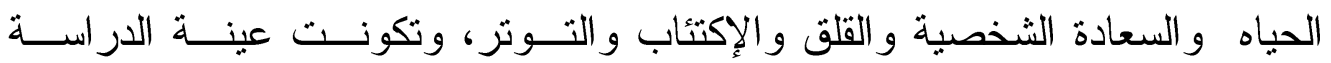

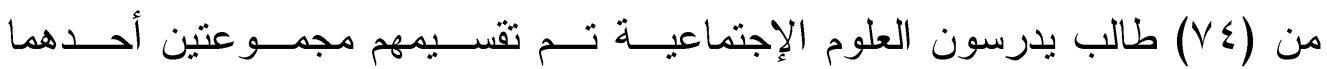

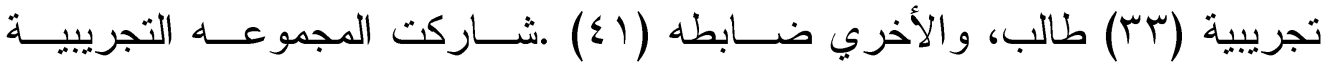

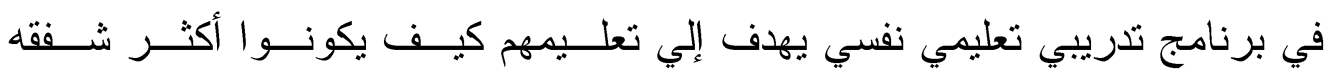

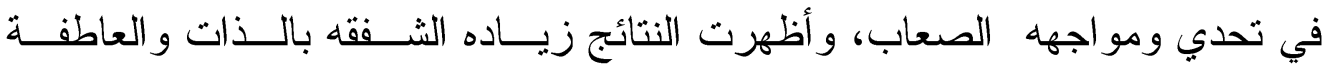

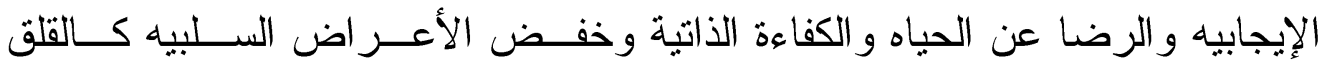

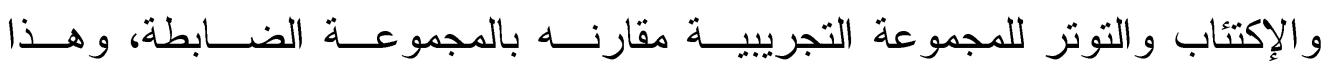
يؤكد الدور الحيوي الذي تلعبه الثفقه بالذات علي الحاله النفسيه للفرد .

Psychological Resilience: ثانيآ : الصمود النفسي

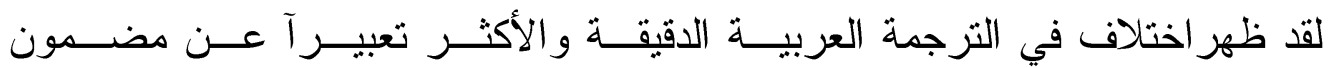

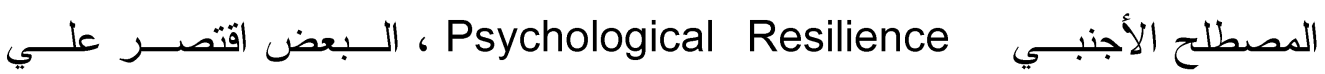

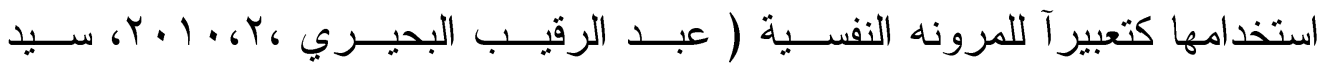

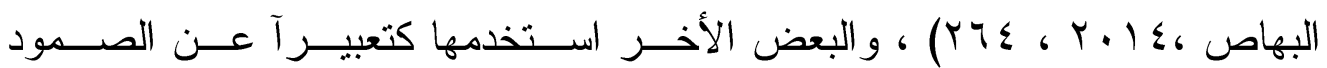

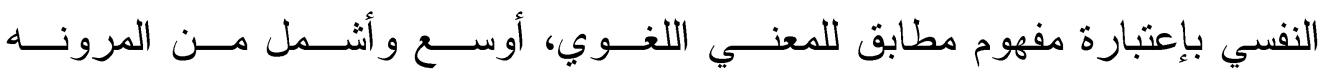

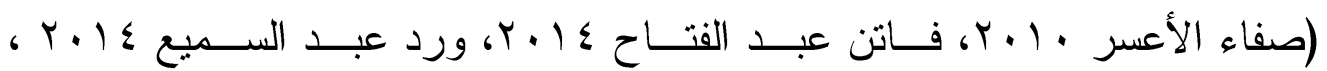

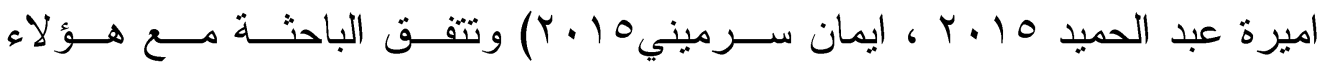

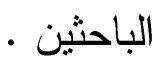

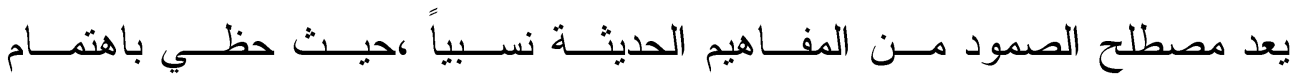

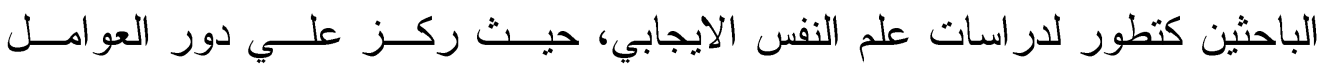

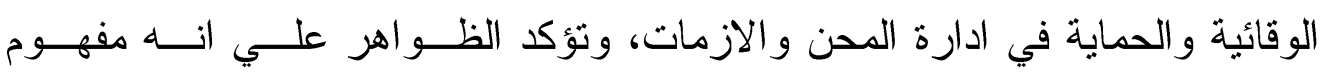

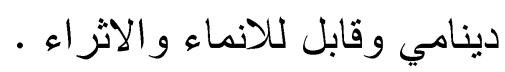

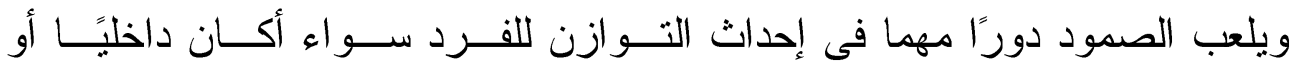

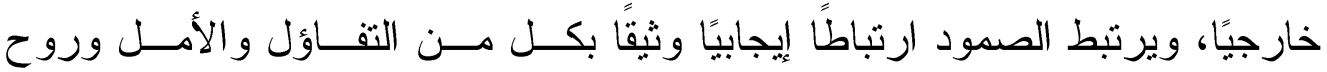

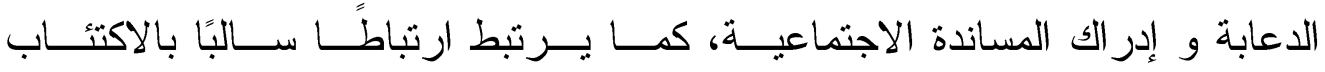
و اليأس و الثعور بالألم(Sahin K.,2016, Aydogdu,et al,2017)). 


\section{Iro}

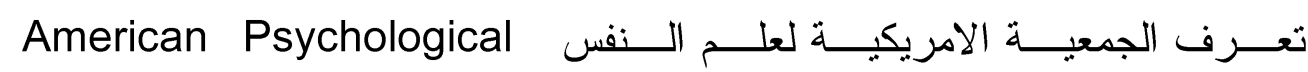
Association

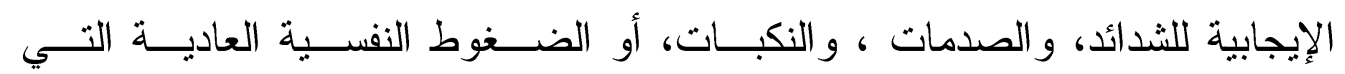

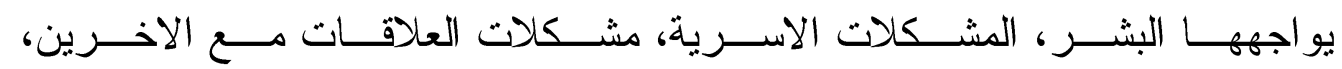

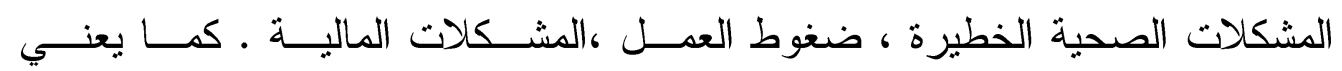

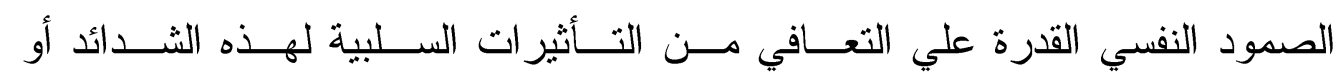

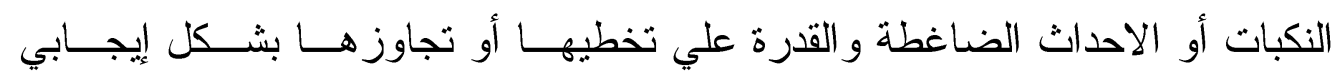
ومو اصلة الحياة بفاعلية و اقتنار " (APA , 2000)

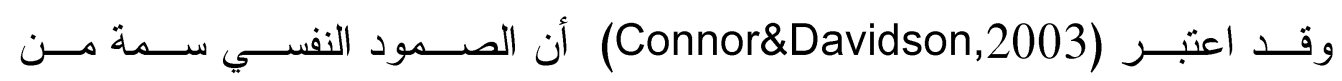

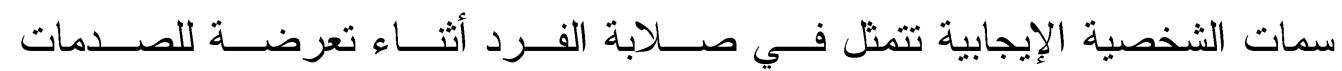
وقدرته علي استعادة توازنه وسعة حيلته لتحقيق أهدافه .

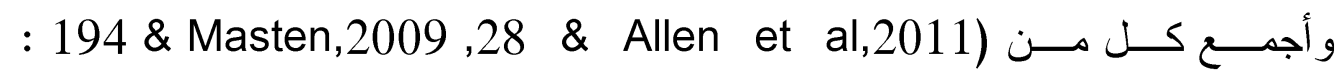
(Benetti \& kambourpouls ,2006 \& Smith et al., 2008

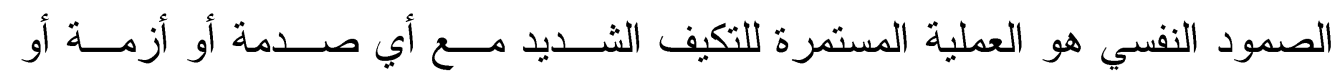

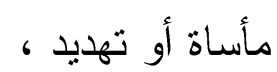

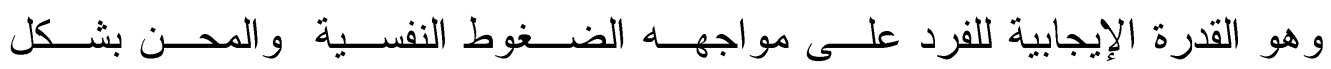

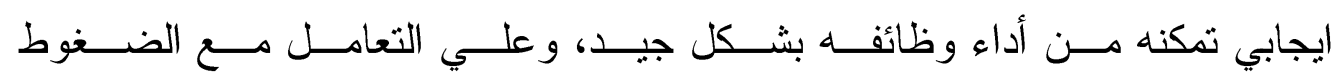

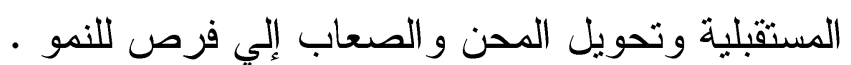

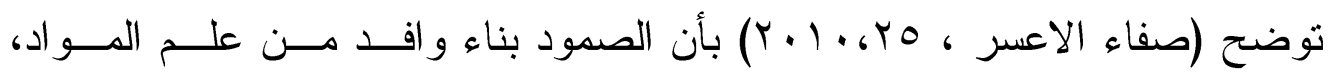

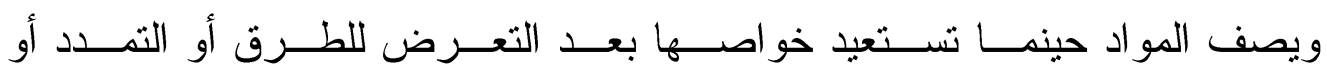

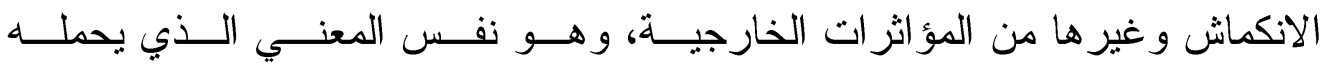

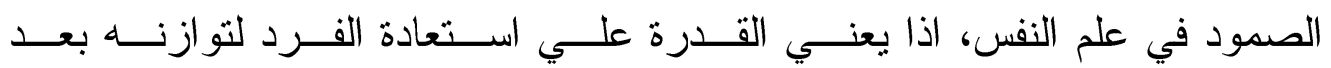

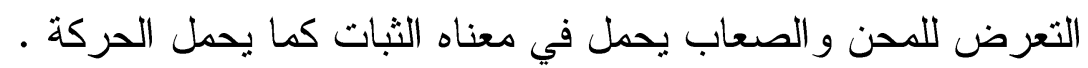

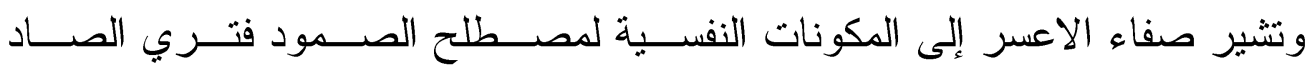
"صلابة " وفي الميم "مرونة" وفي الواو "وقاية " وفي الدال "دافعية " . 


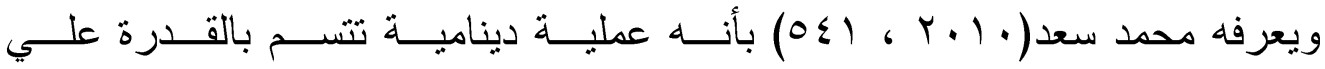
التو افق النفسي مع كافة التهديــدات و الضـــوط بشــتي الصـــور، و القــدرة علــي استعادة الفاعلية وسر عة التعافي بعد الإنكسار .

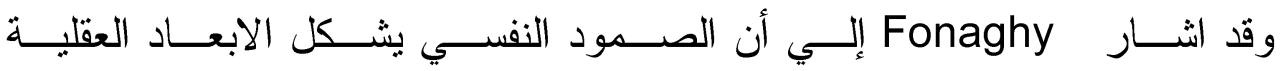
و الاجتماعية و النفسية و الانفعالية لشخص الانسان، ويمكـن تحديــده مـن خــلله:

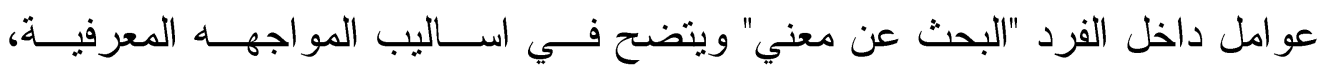
ومستويات الكفاءة الذاتبــة و الاجتماعيــة، و الاحســاس بالضــبط ويتضـــح فــي : مو اجهة الثدائد، وتر اكم المهار ات و الخبرات، الحفاظ علــي الهويـــة ويتضـــح فــي تحقيق الاهـــداف الشخصــية، مو اجهــة التحــديات ـ و وعو امـلـل خاصـــة بــالمنزل ويتضح في الوضع الاقتصـادي والاجتماعي، واســاليب التشــئة الاســرية، و القــيم

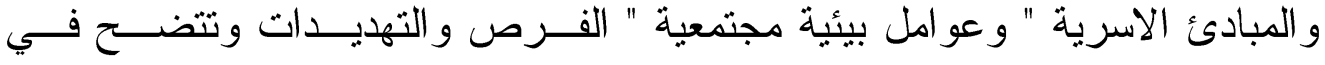
: تأثير المدرسة ، و الاقــران، ووســائل الاعــلام، درجــة المســـاندة الاجتماعيــة

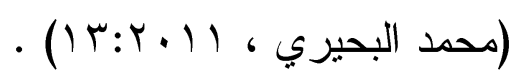

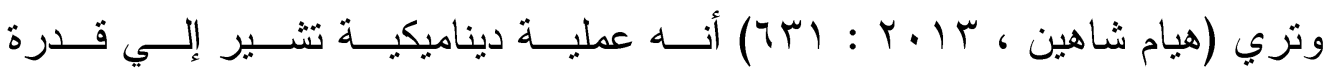

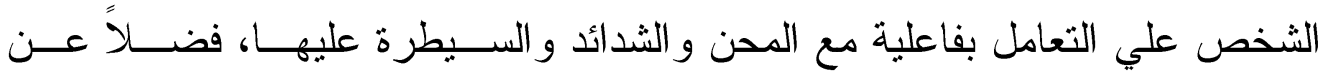
إمكانية استعادة الثقة والتعافي بعد التعرض للأحداث شديدة الوطأة .

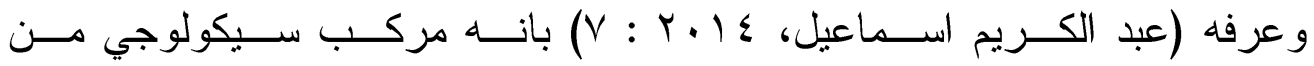
مجموعة من العو امل النفسية المتفاعلة و التي تمكــن الطالــب مــن عـــدم الانهيــار

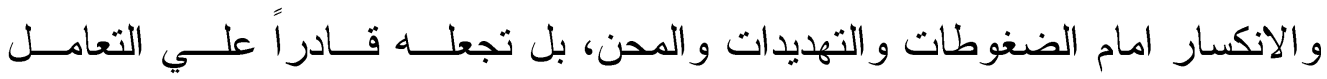
معها بكل صلابة، و التفكير بها بمرونه، مع وجود مســتوي عـالي مــن الدافعيــة، تمكنه من التو افق معها ، و الانجاز و التقدم و النجاح في الحياة .

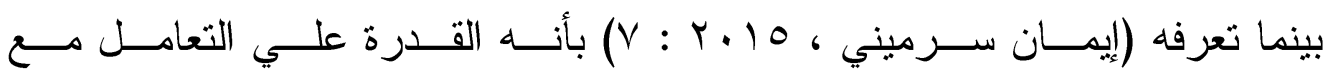
ضغوط الحياة ومشقاتها ومصـائبها من خلال الاعتمــاد علــي المصـــادر الداخليـــة

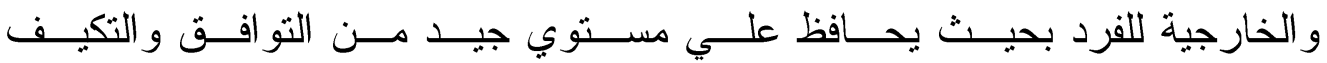




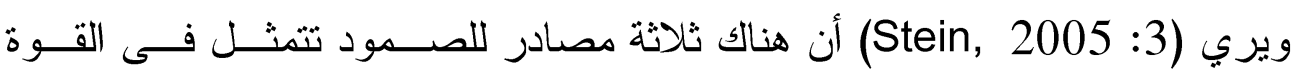

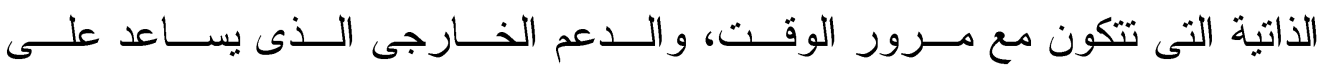

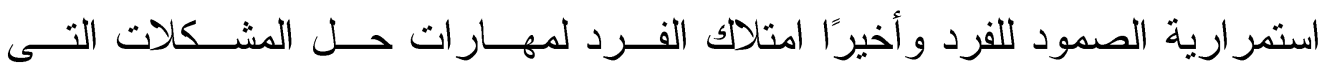
تساعد على مو اجهه الثدائد و الصعاب.

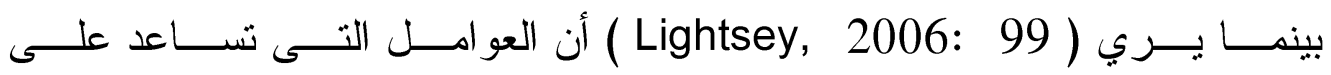

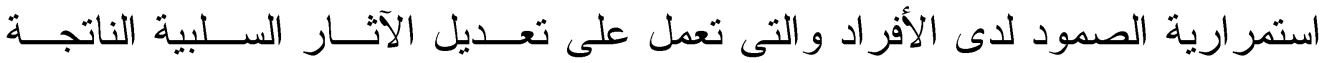

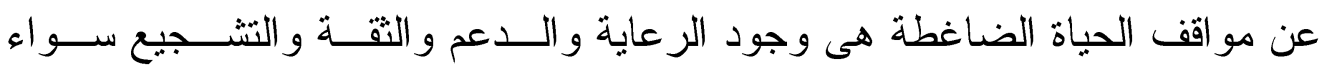

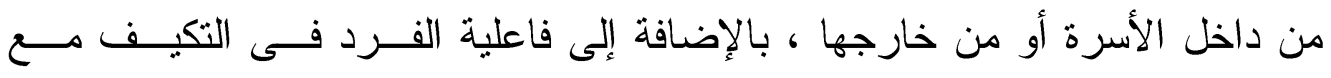

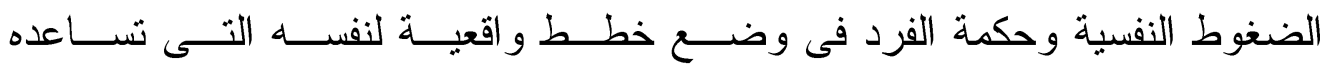
على حل المشكلات التى تو اجهه.

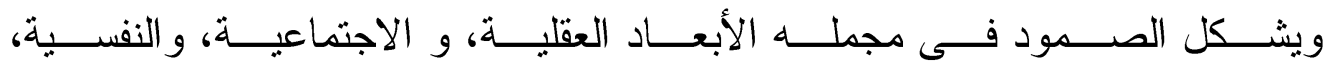

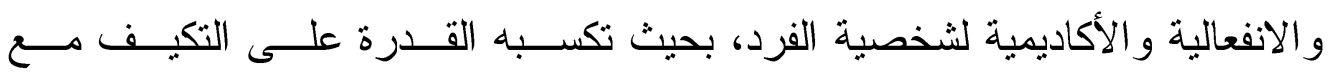

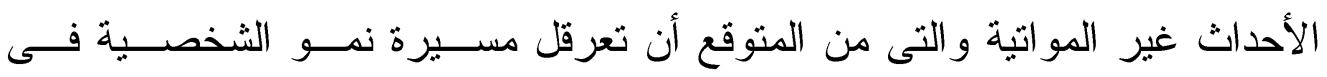

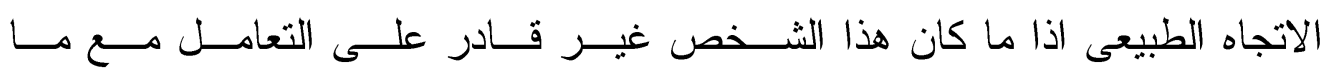

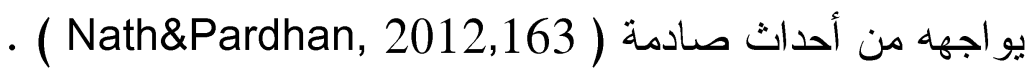

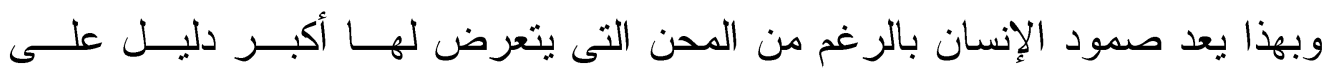

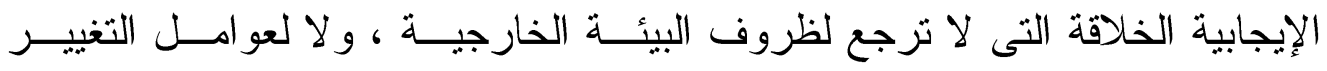

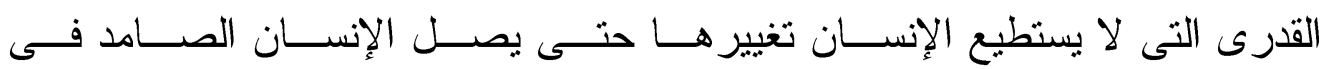

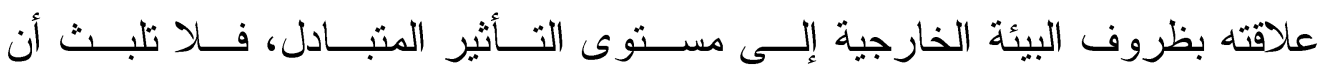

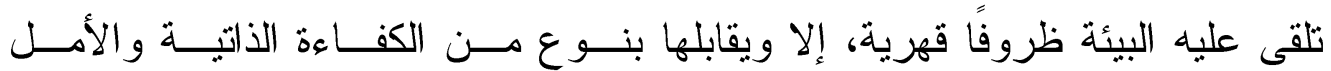

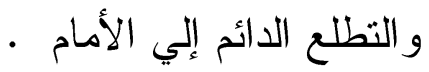

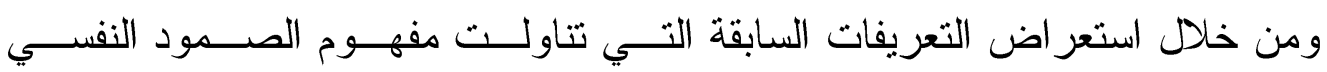

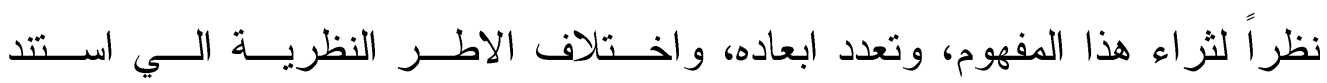

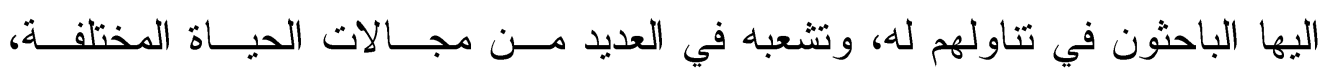

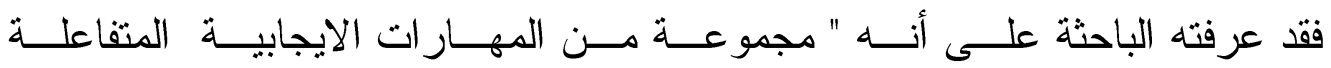

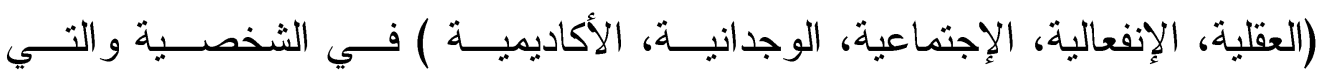


تعمل علي إيجاد بنية نفسية قوية لاي الطالــبـ الجــامعي تســاعده علــي التكيــف

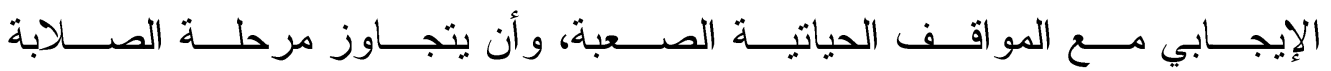

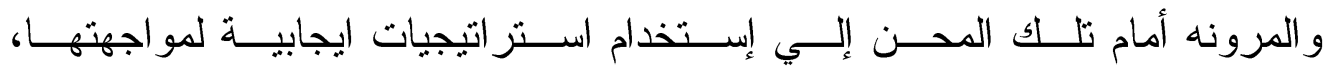
ويقاس من خلال خمسة أبعاد ( الكفاءة الأنـــة - المرونـــه - حــل المشــكلات المثابرة وتخقيق الهدف - الكفاءة الإجتماعية و الوجدانية) . النظريات المفسرة لمفهوم الصمود النفسي : تتعدد التوجهات النظرية لتفسير الصمود النفسي منها :

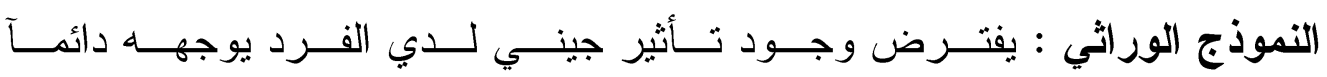

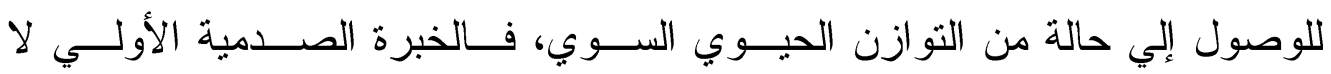

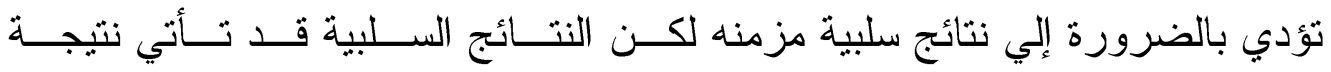
تر اكم وتكر ار الضنوط و المخاطر . (Goldstien \& Brooks,2006,5).

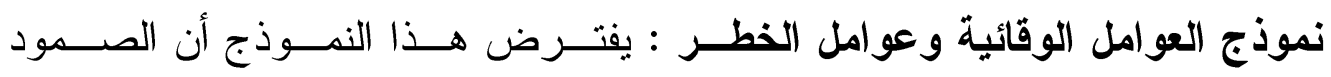

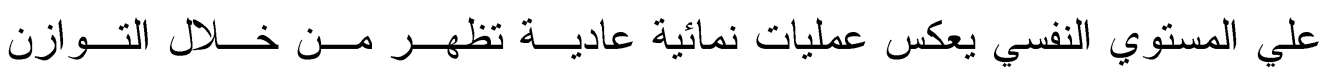

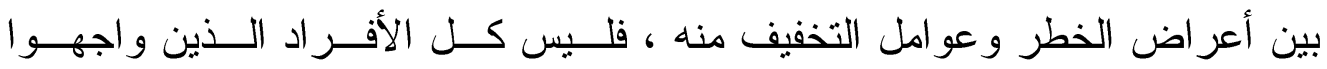

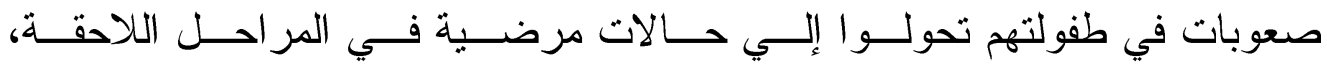

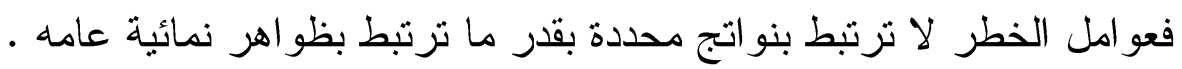

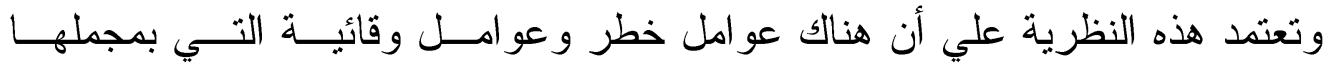

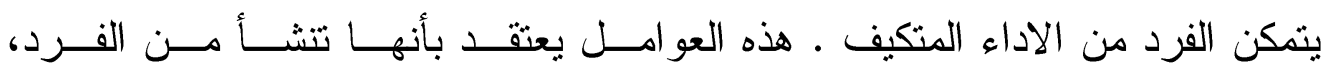

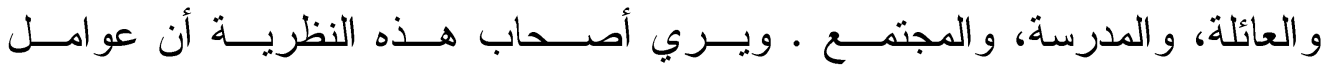

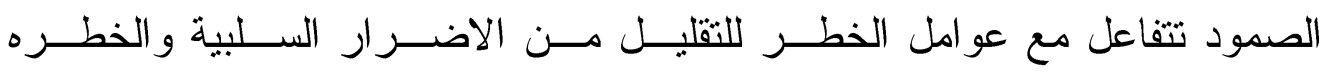

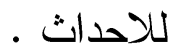

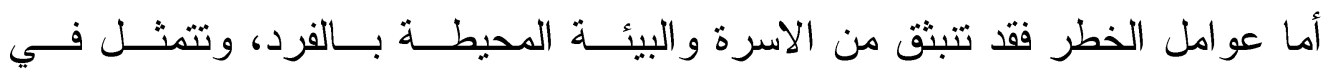

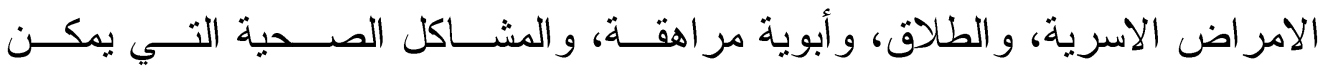

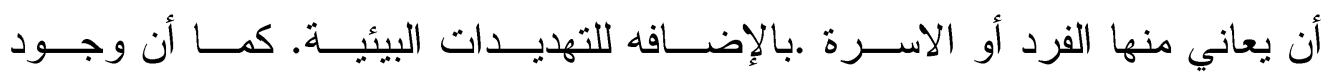

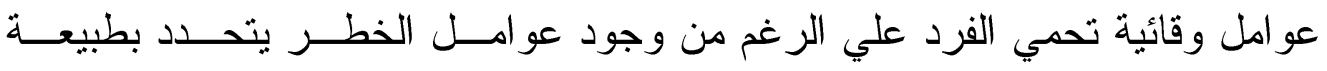
التفاعل بين تلك العو امل بنو عيها. 


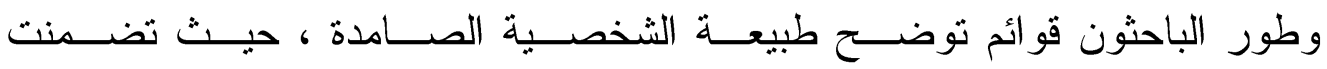

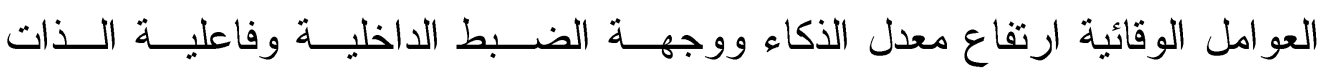

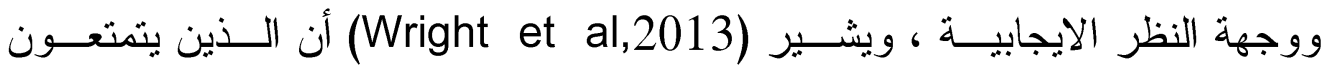

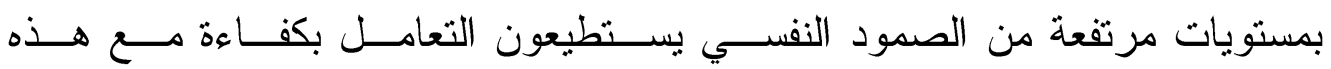

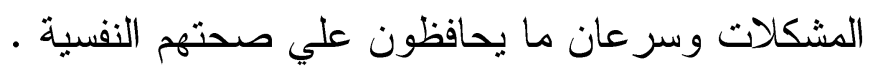

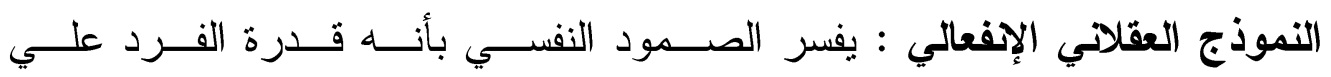

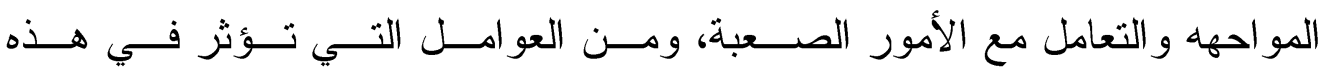

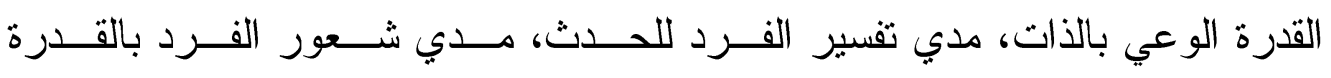

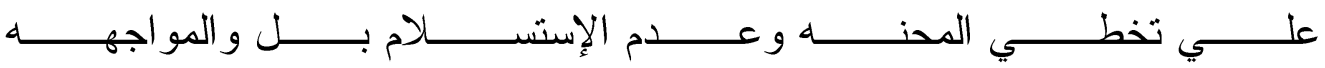
• (Ellis\&Bernard,2006,156)

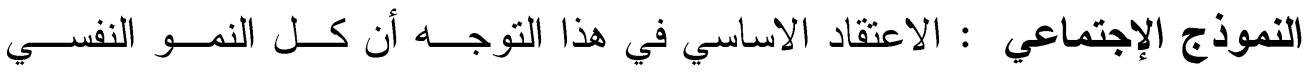

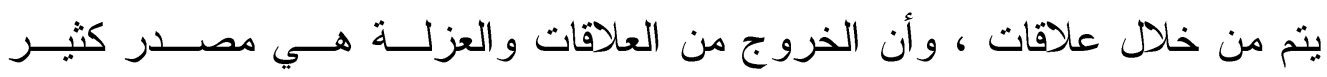

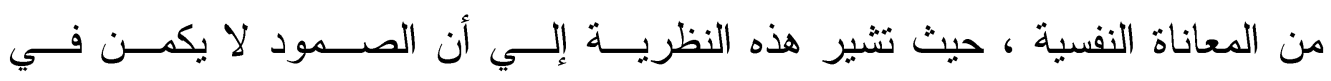
الفرد و إنما في القدرة علي التو اصل و الارتباط.

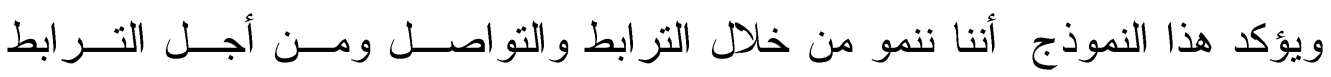

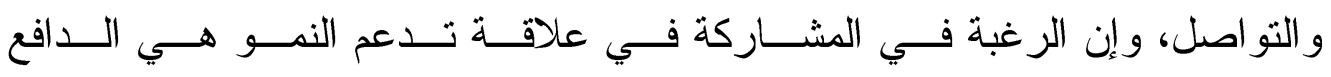

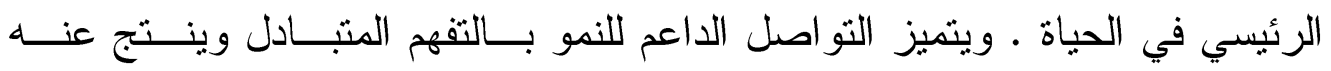

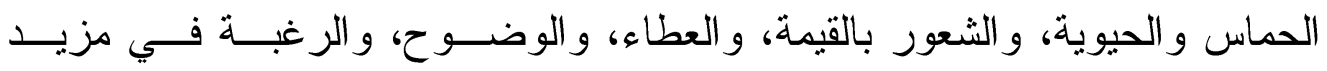

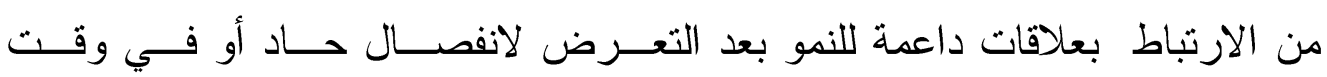
الثدة .

ويتضمن النموذج الإجتماعي للصمود مجموعه من المبادئ تتمنل في :

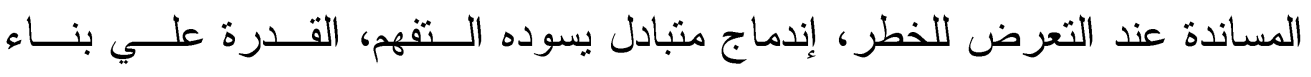

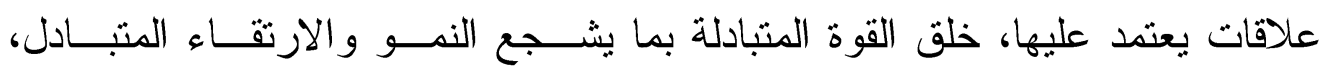

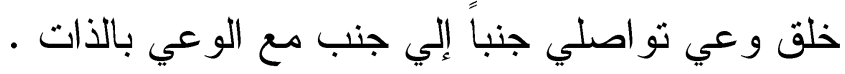

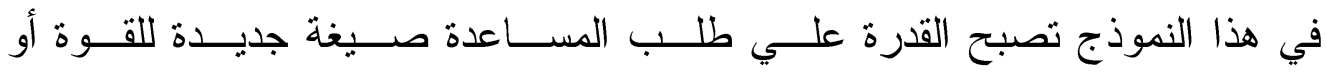

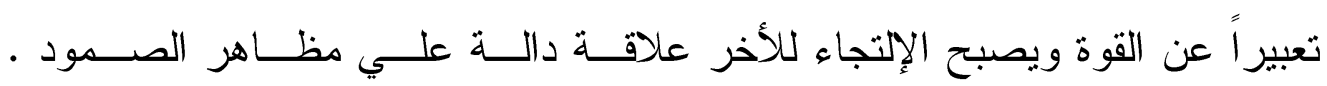


إذن يتضمن الصمود التو اصلي التحرك نحو علاقات تــدعم القــوة المتبادلــة فــي

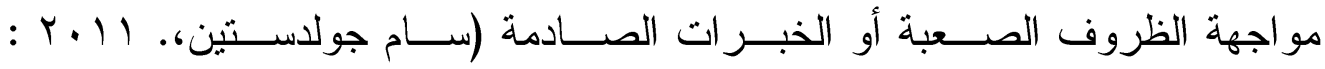
( $(1 \leq \Lambda-1 \leq V$

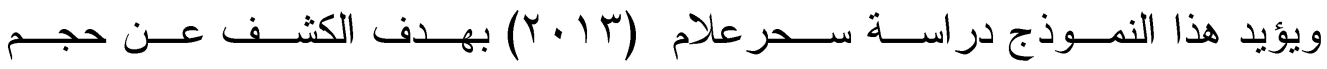
العلاقة بين الصمود النفسي و التماسك الأســري لــدى عينــة مــن طالبــات كلبـــة

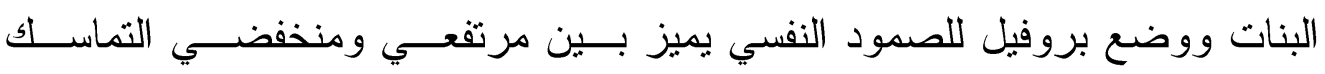

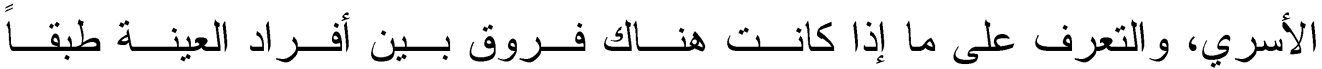

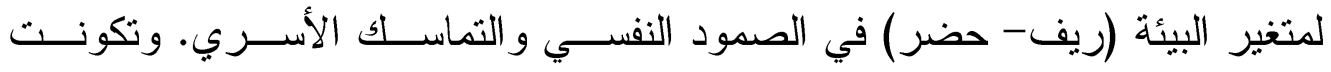
عينة الدر اسة من اهم طالبة من طالبات الفرقــة الثالثــة و الر ابحسـة مــن الأقســام الأدبية و العلمية بالكلية بمتوسط عمري قـدره س rV.Y و انحــر اف معيــاري قــدره 19.79. وقد استخدمت الباحثة مقياسـي الصــمود النفسـي و التماســك الأسـري (إعداد الباحثة) وقد توصلت النتائج إلى وجــود علاقــة ارتباطيــة موجبـــة دالـــة

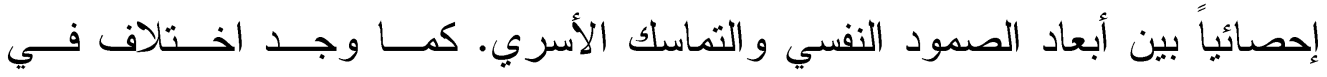

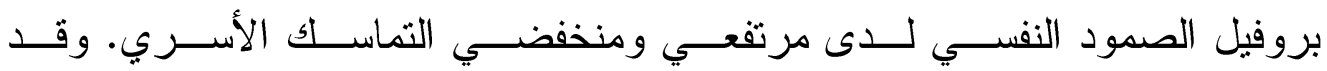

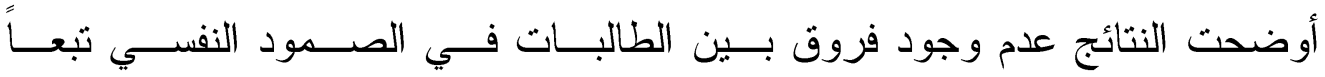
لمتغير البيئة (ريف- حضر) . وتزي الباحثة أن الصدود النفسي مفهوم أوســع و أثــمل مــن أن تفســره نظريـــة

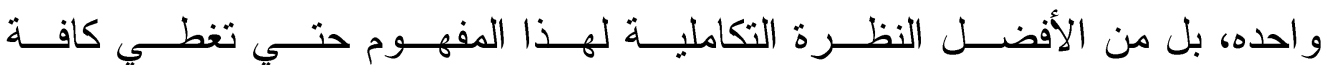

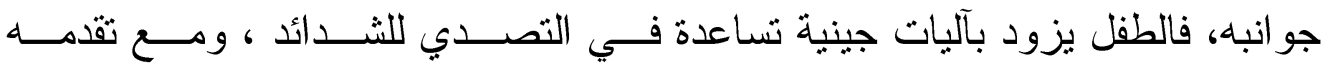
في النمو يو اجهه العديد من المحن، ولكــن علاقتــهـ الجيــدة مـــع القــائمين علــي رعايته تمكنه من التعامل بفعالية مــع المواقــف الحياتيــة الســلبية، وأن يتجــاوز هذه الصعاب، ومع التطور في النمو تــزداد وتتتــوع الصـــوبات التــي يو اجههـــا

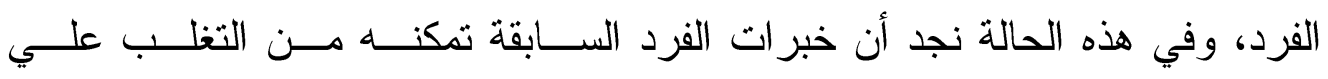

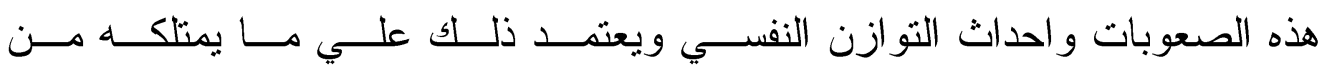
سمات شخصية تؤ هله للصمود النفسي. 
سمات الأفر اد الصامدين نفسياً:

أثـــار ( William, et, al, 2001, إلــى عـدة خصـــائص يتميـز بهـــا الطلاب الصامدون نفسياً وهى : • - مستوى عال من دافعية الانجاز • • مستوى عال من السلامة النفسية. - فاعلية للذات. -

" القدرة على مو اجهة الشدائد و الصعاب. • بينما يذكر ( Van Galen et al 2006, 6 ) عددا مــن الســمات التـي يتصــف بها الأفر اد ذوي الصمود النفسي هي كالآتي : - - إقامة علاقات جيدة مع الآخرين. - مهار ات نو اصلية معرفية جيدة. - ارتفاع مستوى تقدير الذات وفاعلية الذات. - - الإحساس بالهدف من الحياة. - - التدين و الشعور بالانتماء. - - المساهمات في الحياة. - امتلاكك أساليب لمو اجهة الضغوط منو افقة مع طبيعة الفرد و الموقف. - الانفعال الايجابي وروح الدعابة. - امتلاك المهار ات الفعالة في حل المشكلات. - الإيمان بأن الضغوط يمكن أن تزيد الفرد قوة.

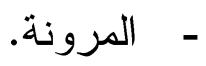

- تقبل المشاعر السلبية ومحاولة تخطي الخبرات السلبية. - التعامل الصحيح مع الضغوط و اعتبار ها تحديات ينبغي مو اجهتها. دراسات تناولت الصمود النفسي : لمزيد من التعرف علي طبيعة الصـــود النفسـي لــدي طــلاب الجامعـــة يـتـ

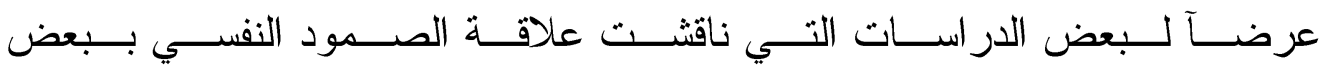


المتغير ات النفسية ( فاعلية الــذات، الحكمــة ، العصـــابية، الإنبســاطية، الوجـــــان

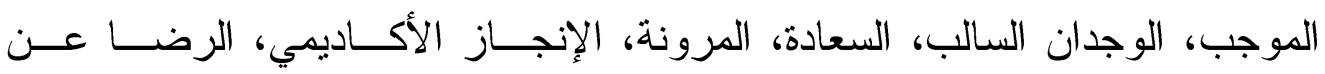

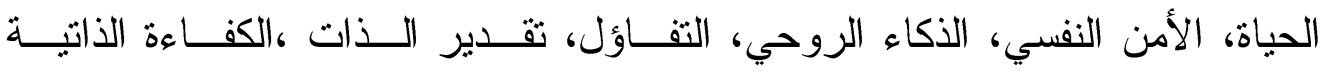
الوجدانية، الكفاعة الإجتماعية ) وهي علي النحو التالي :

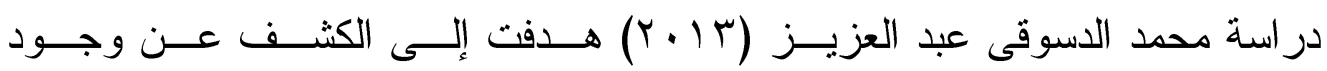
علاقة ارتباطية بين الصمود النفسي وفاعلية الــذات لــدى طلبـــة جامعــة القـــس

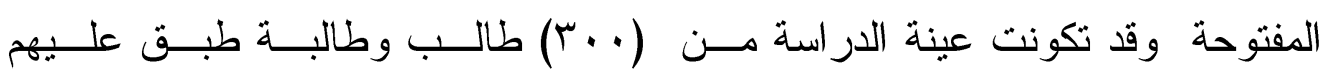

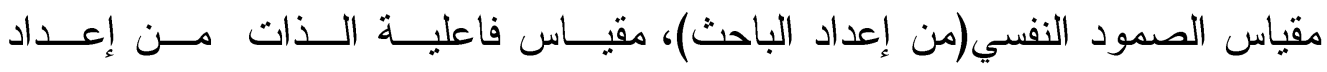

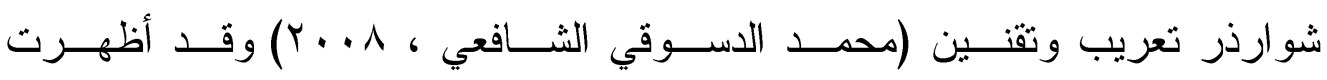
نتائج الدر اسة وجود علاقة ارتباطيــة بـين الصـــود النفسـي وفاعليــة الــذات،

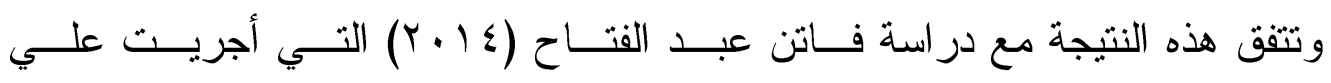

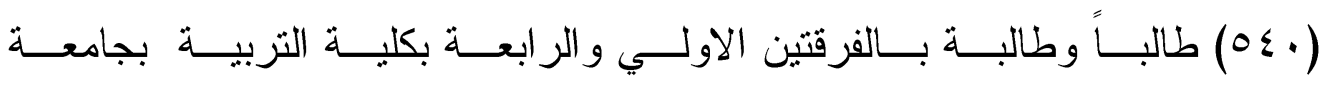
الزقازيق ، بهدف التعرف علي العلاقة بين الصمود النفسـي وكــل مــن الحكمـــة

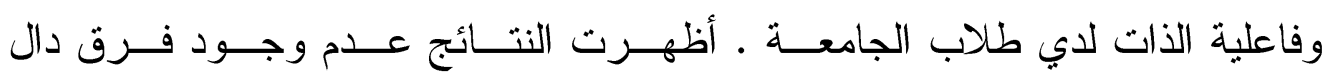

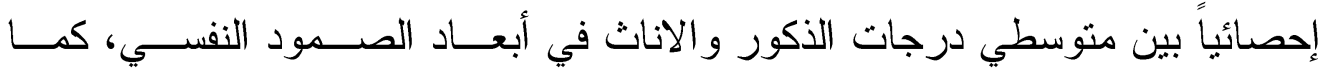

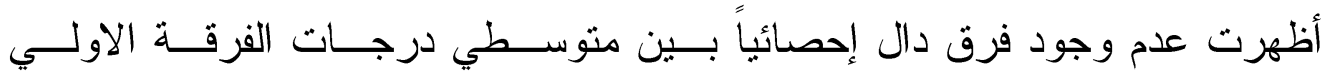
و الفرقة الر ابعة في الصمود النفسي بأبعادة الاربعــة (الصــلابة ،التهـــاؤل ،وفــرة

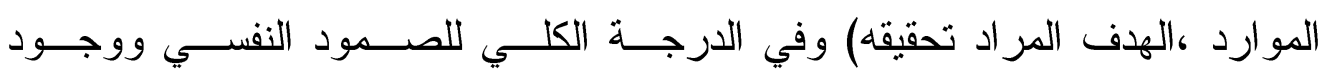

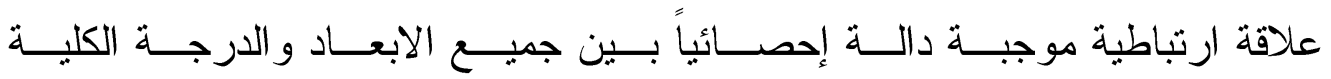
للصمود النفسي وجميع الابعاد والدرجة الكلية للحكمة لدي طلبة الجامعة .

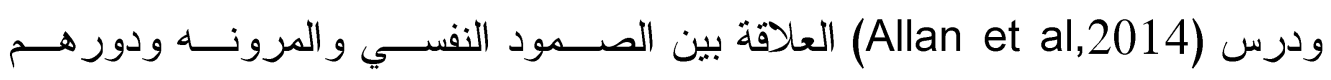

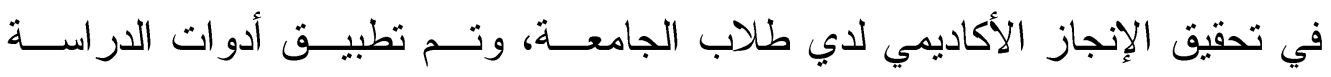

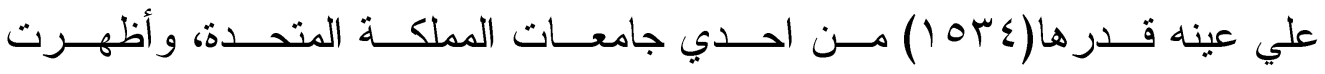

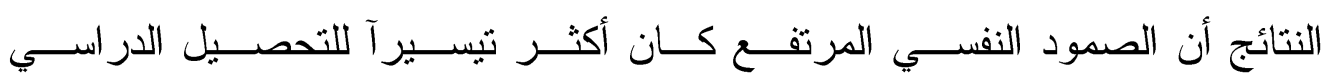
المتوقع لدي الإناث أفضل من الــذكور، كمـــا أثــارت أن العلاقـــة بــين القــدرة علي الصمود و الإنجاز الأكاديمي تتطلب مزيدآ من المرونه النفسية . 


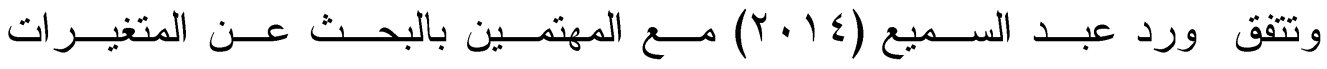
الإيجابية ذات الصلة بالصمود النفسي لـدى الطالبــة الجامعيــة، هــدفت در اســتها

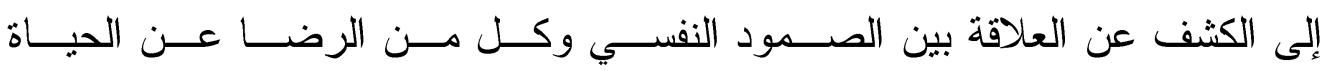

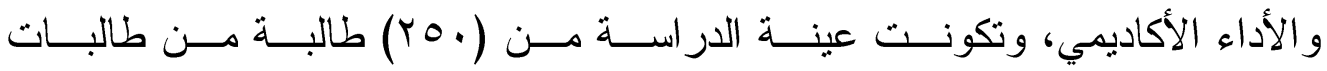
الفرقة الثانية و الثالثة بكلية البنات للآداب و العلوم و التربيـة جامعــة عـين شــمس،

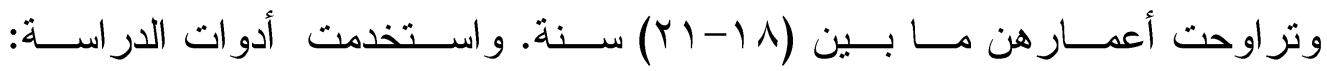

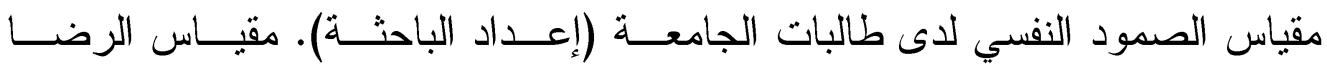
عن الحياة (إعداد مجدي محمد الدسوقي، 999 1)). أســفرت نتــائج الدر اســـة عـنـ

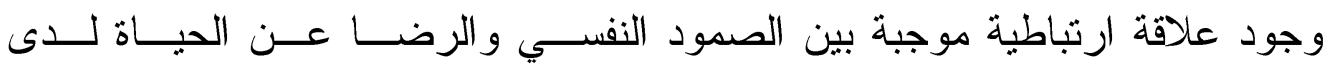
طالبات الجامعة ، وجود علاقة ارتباطية موجبــة بـين الصــمود النفسـي والأداء الأكاديمي لاى طالبات الجامعة. ودرس (Kajbafnezhab et al,2015) امكانية التتبـؤ بالصــمود النفسـي مــن

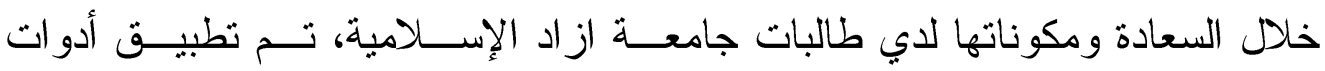

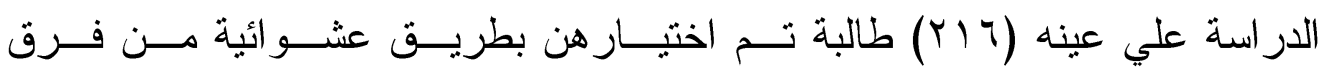

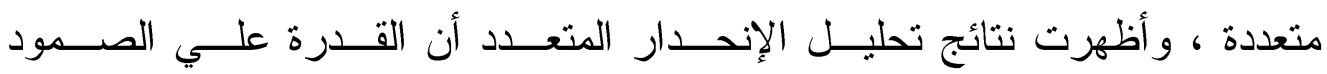
النفسي تزتبط بشكل ايجابي وكبيربجميــع أبعــاد الســعادة، وأن الســـعادة النفســية

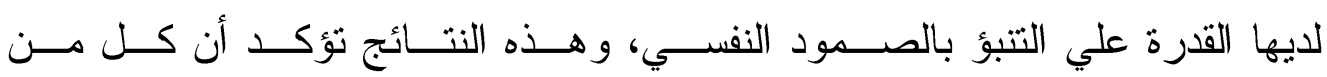

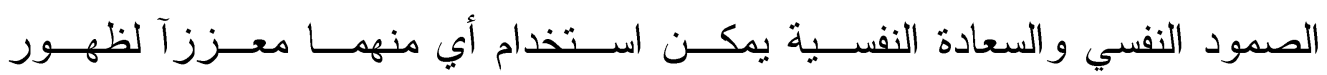
الآخر .

و اهتمت در اسة (Sahin et al,2016) بدور تقدير الــذات كوســبط فـــي العلاقــة

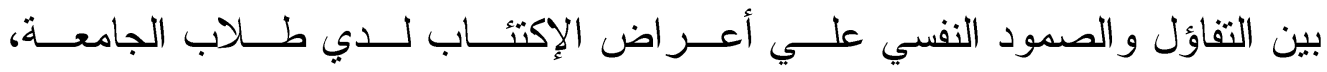

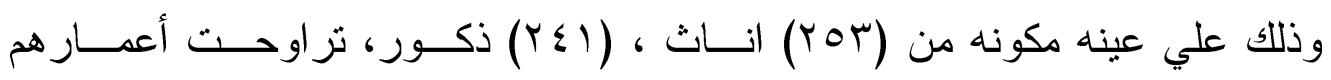

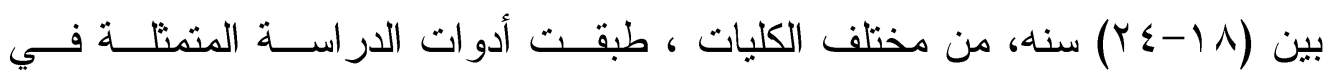
مقياس ( التفاؤل ، الصمود النفسي ، تقدير الــذات ) علــي العينـــه المشـــار إليهــــا و التي تعاني من أعر اض الإكتئاب، و أشـارت النتــائج إلـي وجـــود علاقةارتباطيــة

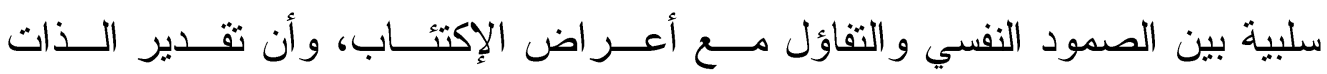




\section{$1 \leqslant \varepsilon$}

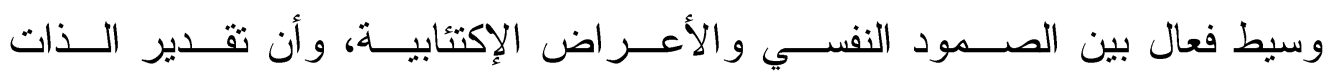

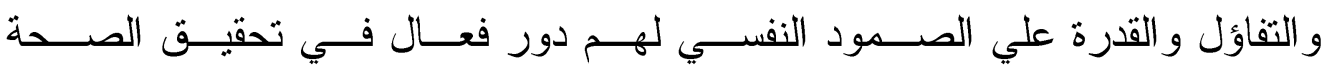
النفسية للفرد .

وتوصل ( Aydogdu et al,2017) انه بمكن التتبــؤ بالقــدرة علــي الصـــود

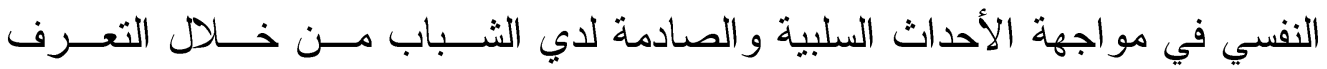

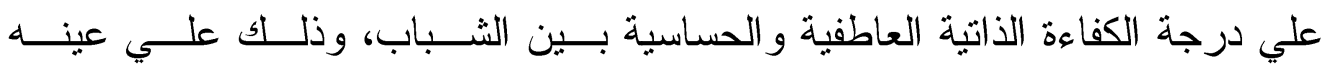

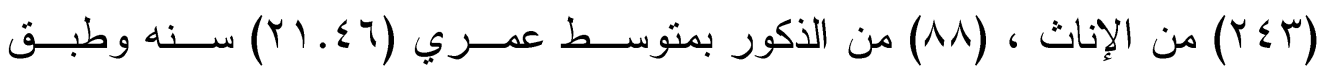

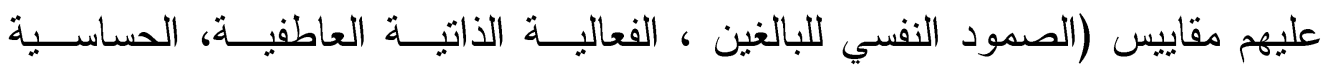

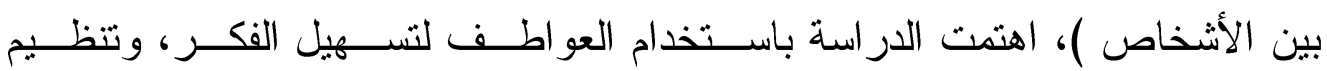

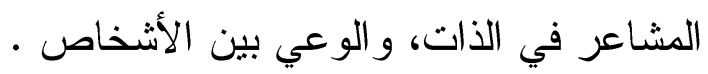
العلاقة بين الثفقة بالذات و الصمود النفسي :

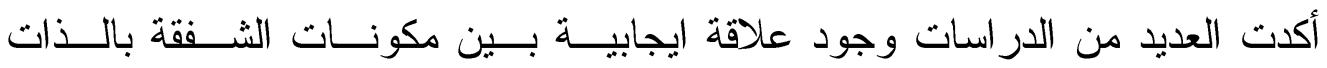

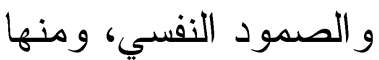

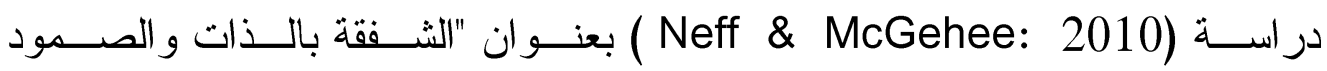

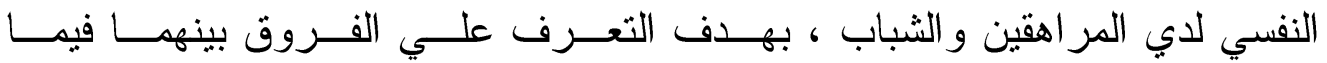

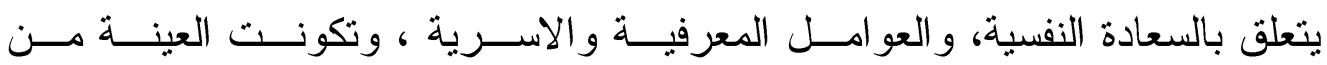

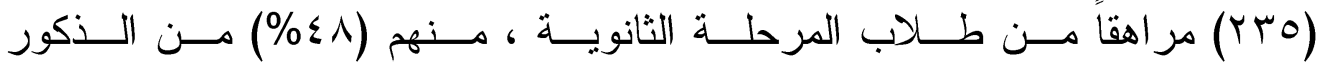

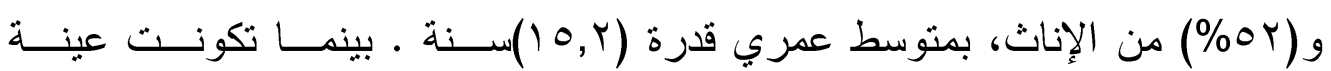

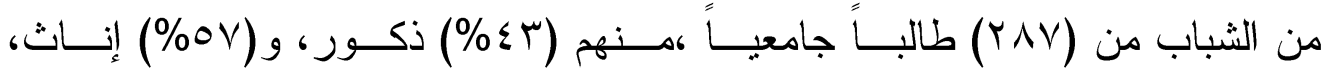

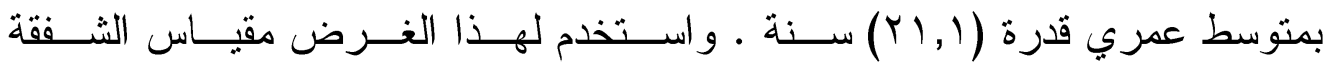

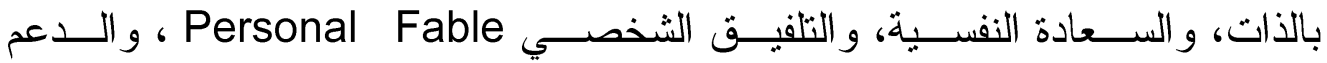

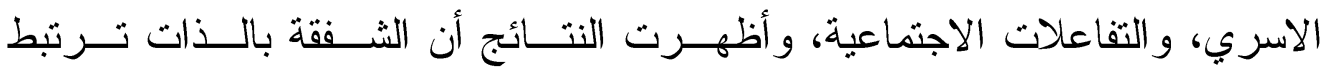

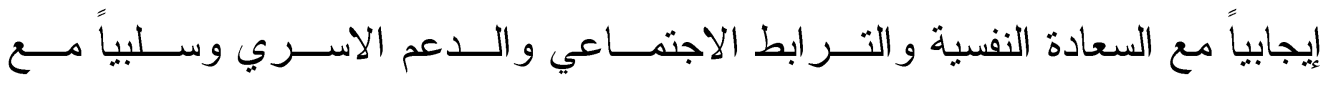

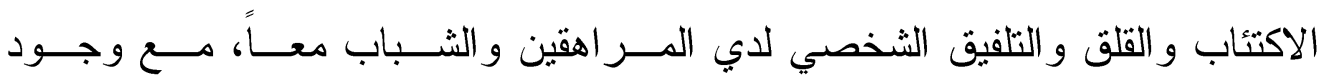
فروق بين الذكور والإناث في الثفقة بالذات لصالح الذكور. 


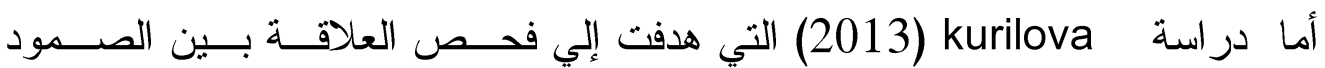

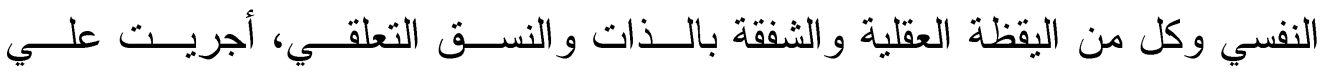

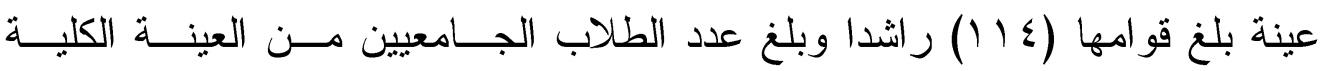

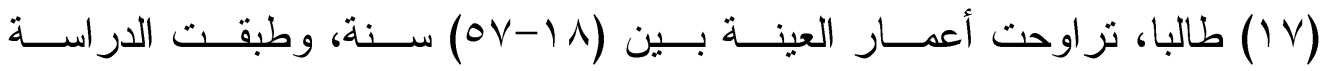

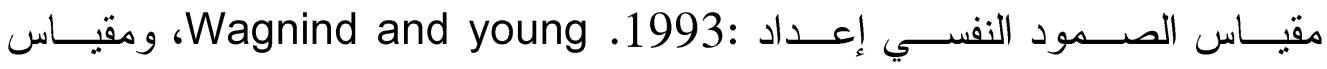

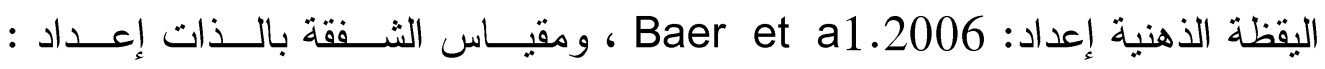

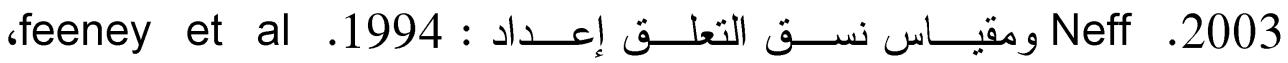

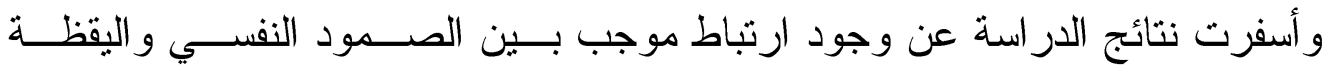

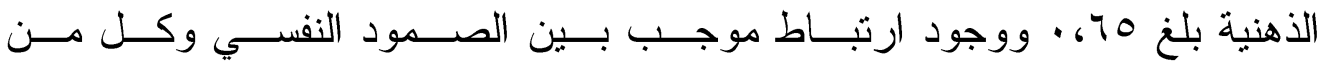

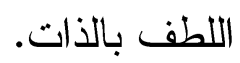

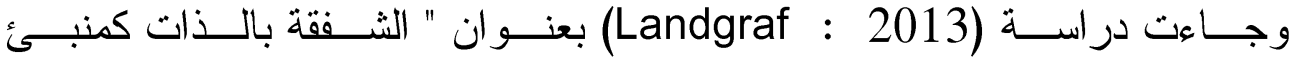

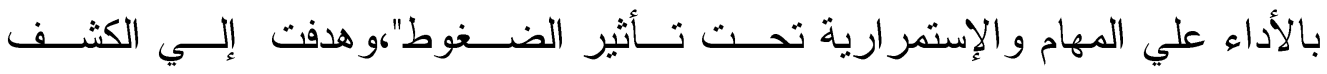

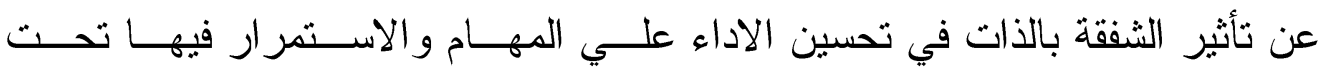

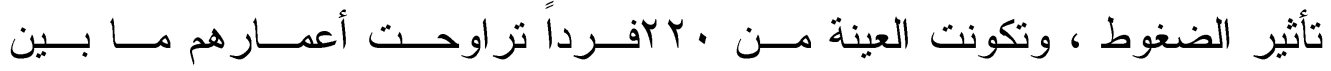

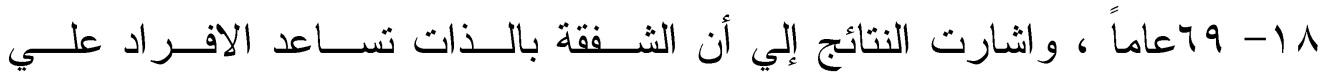

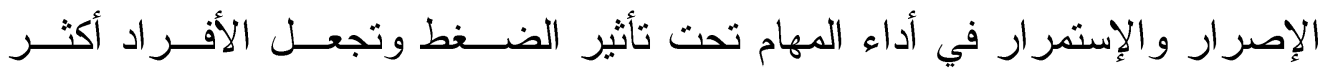
دقة في الإستمر ارفي اتمام الدهام.

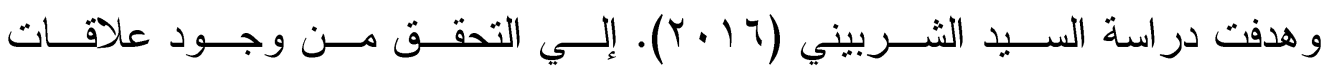
ارتباطيه بين المرونة النفسية (الصمود النفسـي) وكــل مــن العصـــابية و الثــفقة

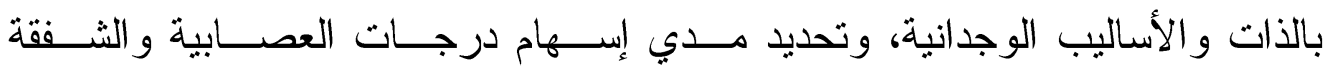

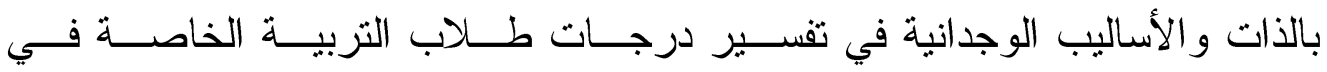

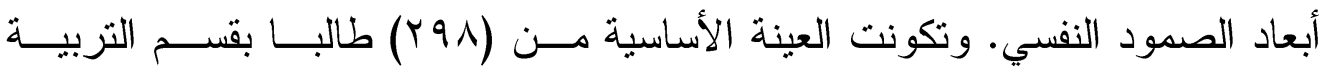

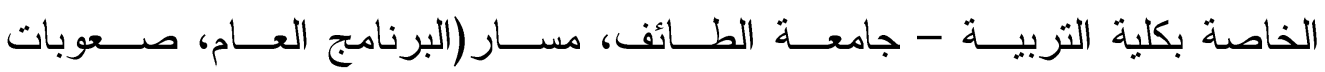

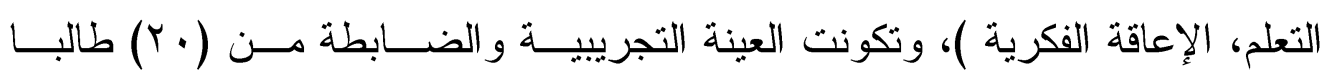

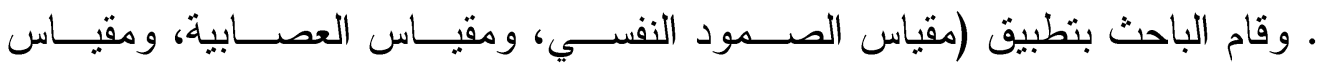

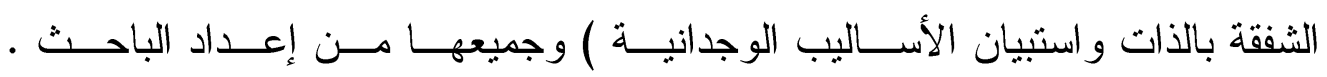




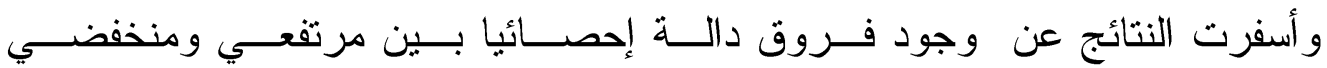

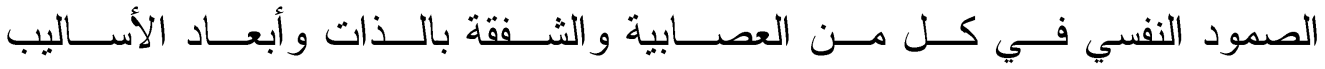
الوجدانية، وجود ارتبــاط ســالب دال إحصــائبا بــين الدرجــة الكليــة الصـــود

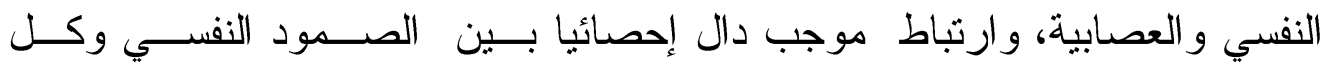
من الثفقه بالذات و أبعاد الأساليب الوجدانية. تعقيب علي الاراسات السابقة :

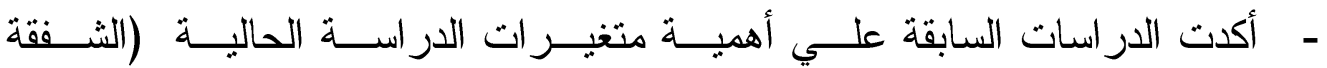

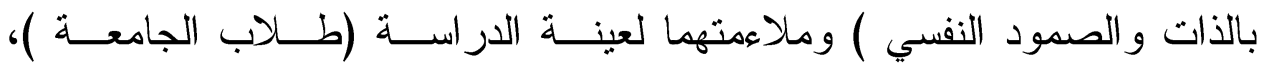

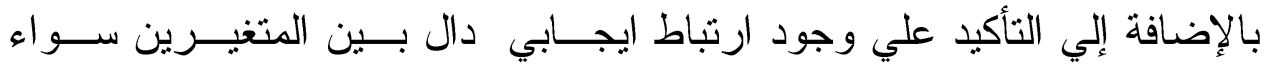

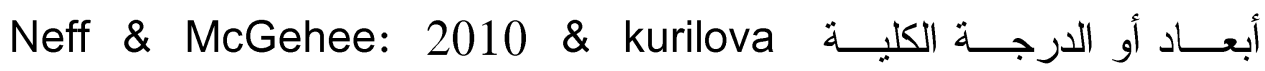

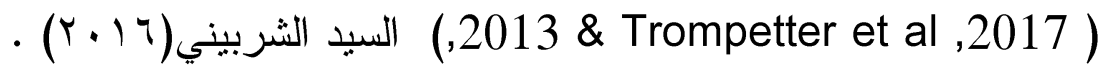

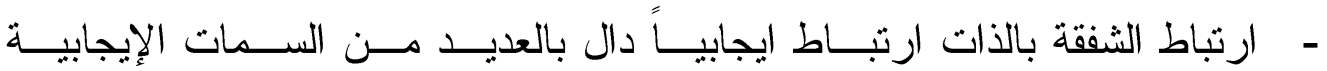

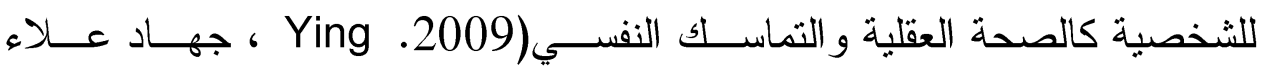

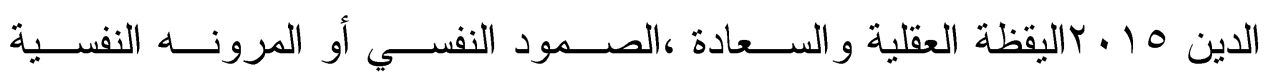

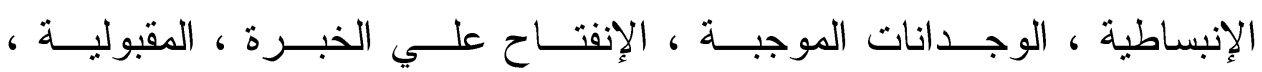

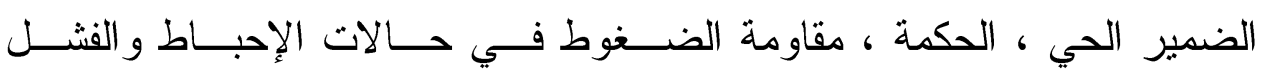
؛ Wurilova 2013 ؛ Walker and Colosimo , 2011)

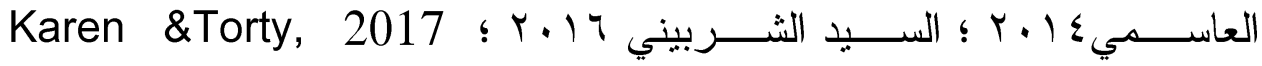

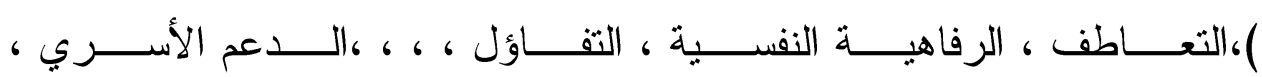

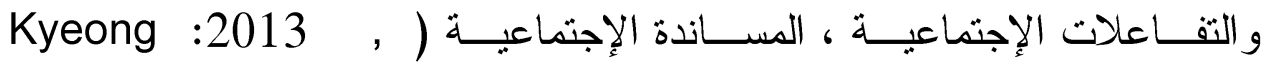
Karakasidou A.,\& Stalikas A. 2017 ؛ Akin\& Kayis 2011 ) جودة الحياه ، الرضاعن الحياة ( Potter ,R. et al,2014. ) Mantelou ,A. et al ؛, Sabaityte E. \& Dirzyte ,A,2016 , 2017

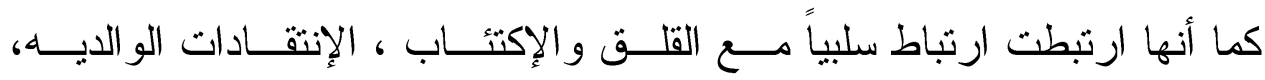

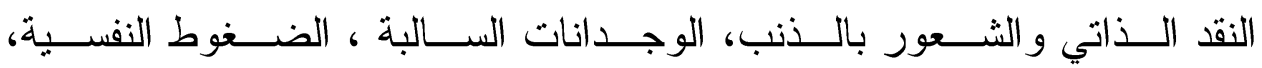




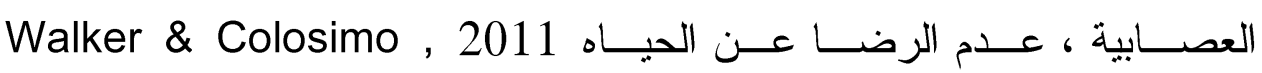
,Kyeong,2013,Potter,R. et al,2014,Lu \&Wang, Y.2014 )

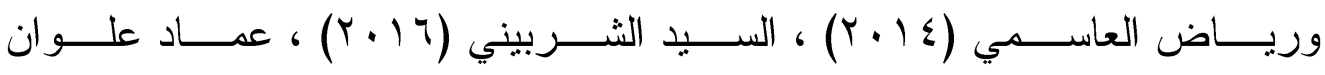
$\cdot(r \cdot 1 T)$

- ارتباط الصمود النفسي لــدي طــلاب الجامعــة ارتبــاط ايجابيـاً بالســمات

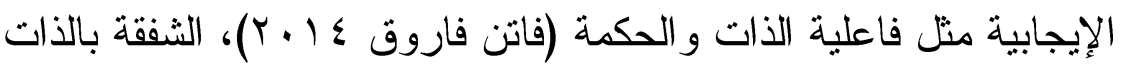

Neff \& McGehee: 2010 \& kurilova ,2013 \& Trompetter -

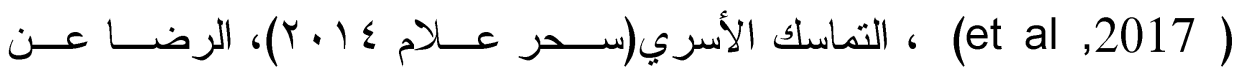

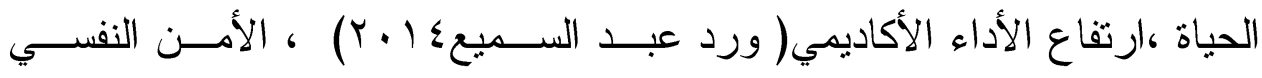

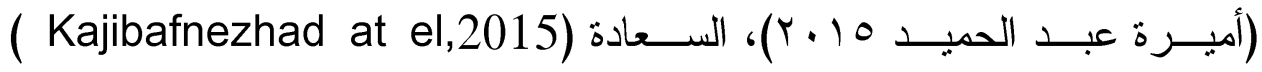

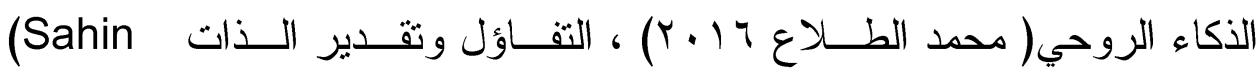
(at el,2016)

.(Aydogdu at el,2017)

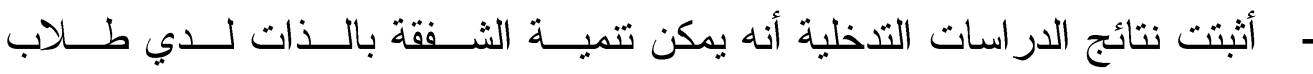

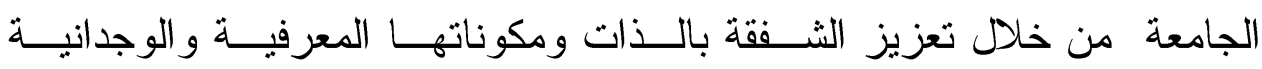

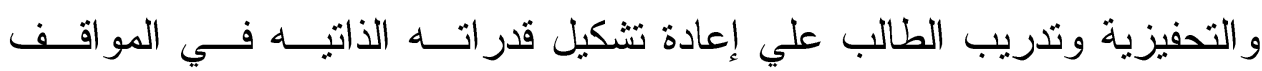

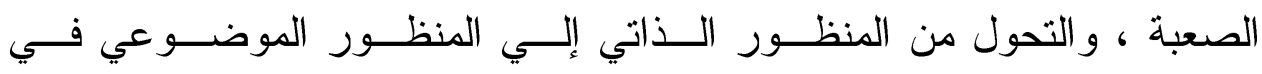

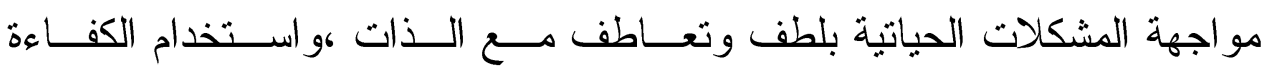

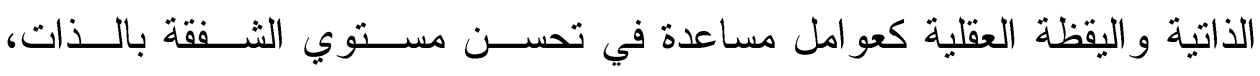

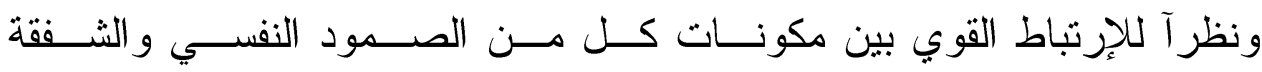

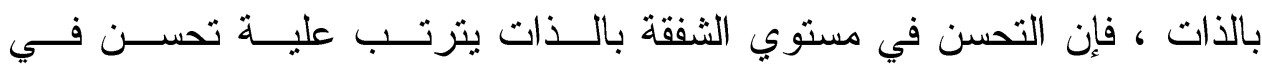

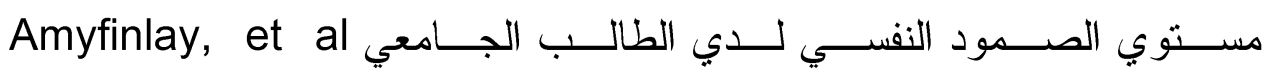
$؛(r \cdot 17)$ Tobias Kriege ,et al $(r \cdot 1 \tau)$

Karakasidou A.,\& Stalikas A."(Karen \&Torty, 2017 ) $(r+I v)$ Mantelou ,A. et al $(r \cdot, v)$ 
في ضوء نتائج الدراسات السابقة و التأصيل النظري لمتغيــرات الدراســة يمكـن صياغة فروض الاراسة علي النحو التالي :

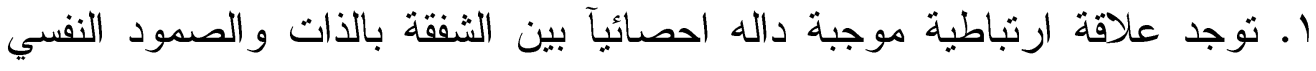

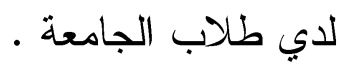
r. توجد فروق ذات دلالة احصائية بين منوسطي رتب درجات طلاب المجموعة لاته التجريبية في القباسين القبلي و البعدي علي مقياسي الثفقة بالذات و الصمود النفسي

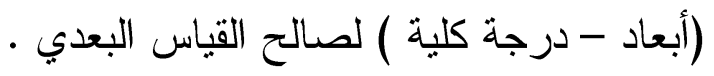

r. توجد فروق ذات دلالة احصائية بين متوسطي رتب درجات طلاب المجموعتين

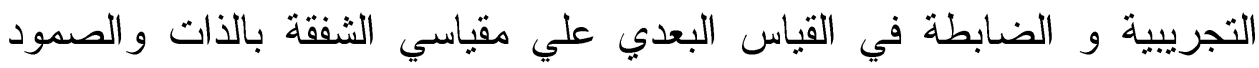
النفسي (أبعاد - درجة كلية ) لصالح المجموعة التجريبية

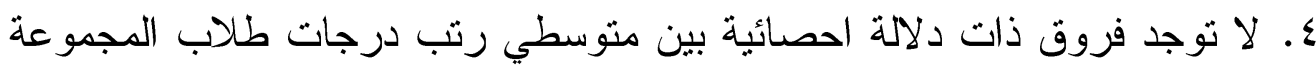
التجريبية في القياسين البعدي والتتبعي علي مقياسي الثفقة بالذات والصمود

$$
\begin{aligned}
& \text { النفسي(أبعاد - درجة كلية ). } \\
& \text { إجر اعات الارساسة } \\
& \text { - منهج الاراسة : }
\end{aligned}
$$

استخدمت الباحثة المنهج الوصفي لفحص العلاقات بين متغيرات الدراســة (الثــفقة

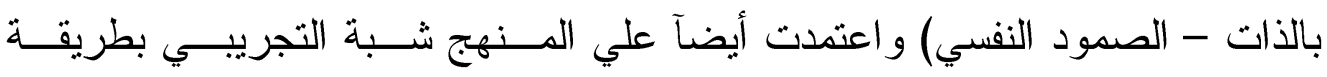

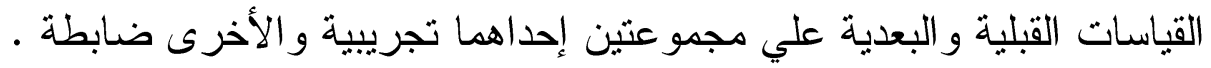

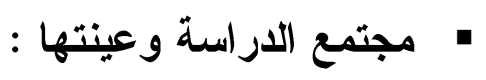

- تكون مجتمع الدر اسة من جميع طلاب كلية التربية بجامعة كفر الثيخ و المقيدين

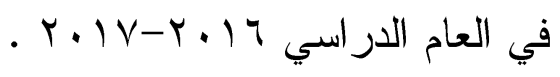

- تكونت عينة حساب الكفاءة السيكومترية لأدوات الدراسة من مجموعة عشو ائية قدرها (r/ ) من طلاب وطالبات الفرق المختلفة للشعب العلمية والأدبية.

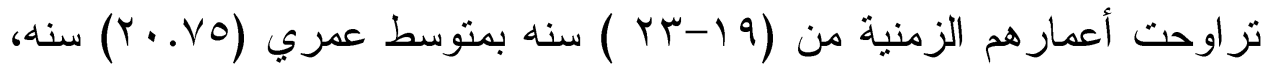
و انحر اف معياري قدره I. YV بكلية التربية جامعة كفر الثيخ.(بإعتبار ها عينه 
ممثلة لطلبة الجامعة بكلياتها العلمية و الأدبية ) في الفصل الدراسي الثاني للعام

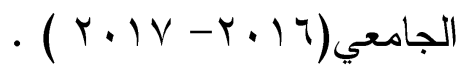
- تم تطبيق مقياسي الدراسة (الشفقة بالذات - الصمود النفسي ) بعد التأكد من كفاءتهما السيكومترية علي عينه ( . . () من طلاب وطالبات( الفرق المختلفة)

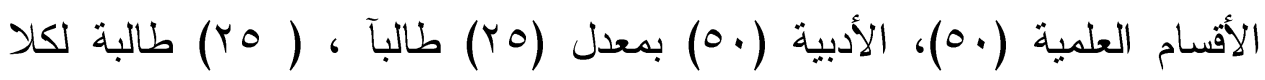

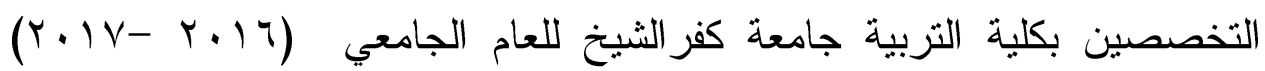
،لإختبار صحة الفروض الفرض الارتباطي. - تم اختيار (Y.) طالب وطالبة من هذه المجموعة وفقآ للمحددات التالية:الحاصلون علي درجات أقل من الإرباعي الأدني علي مقياسي الدراسة بمعدل( مب) درجة فأقل علي مقياس الثفقة بالذات ، (1) درجة فأقل علي مقياس الصمود النفسي.

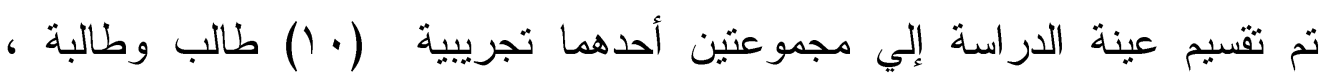
و الأخري ضابطة (· () طالب وطالبة ، وتم تحقيق التكافؤ بينهما في العدر الزمني - الدرجة الكلية لمستوي الثفقة بالذات - الدرجة الكلية لمستوي الصدود النفسي وذللك باستخدام اختبار مان ويتتي ، ويوضح الجدول ( () التالي تكافؤ مجموعتي الدر اسة في هذه المتغير ات . بات البات

جدول(1) الفروق بين متوسطي رتب درجات المجدوعتين التجربيية والضابطة في المتغبرات الخاصة بالتكافؤ

\begin{tabular}{|c|c|c|c|c|c|c|c|c|c|}
\hline \multirow{2}{*}{ غير دالة } & \multirow{2}{*}{ ו } & \multirow[b]{2}{*}{$\leq 7$} & 1.9 & 1.9. & $1 . r v$ & $r \cdot . v_{0}$ & 1. & التجريبية & \multirow{2}{*}{ العمر الزمني } \\
\hline & & & 1.1 & 1.1. & $1.0 r$ & $r .90$ & 1. & الضابطة & \\
\hline \multirow{2}{*}{ غير دالة } & \multirow{2}{*}{1.91} & \multirow{2}{*}{$1 \leqslant$} & 79 & 7.9. & r.A. & rr & 1. & التجريبية & \multirow{2}{*}{ للثفقة بالذات اللية } \\
\hline & & & $1 \leq 1$ & $1 \leqslant .1$. & r.97 & $m 4.9$. & 1. & الضابطة & \\
\hline \multirow{2}{*}{ غير دالة } & \multirow{2}{*}{$\cdot .^{r}}$. & \multirow{2}{*}{$\leq 4$} & 1.1 & 1.1. & 0.99 & Vr.A. & 1. & التجريبية & \multirow{2}{*}{ الصدوجة النفسية } \\
\hline & & & 1.9 & 1.9. & \&.Y & $V \varepsilon . r$. & 1. & الضابطة & \\
\hline
\end{tabular}


أدوات الاراسة :

أولا مقياس Self-compassion Scale أعداد ( Neff,2003a).

الثفقة بالاتات

حيث اعتمدت في بناء المقياس علي نموذج ثلاثي الأبعاد ، منتكلة في سته أبعاد فرعية

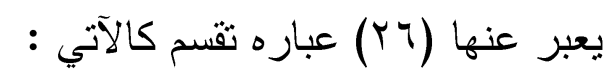

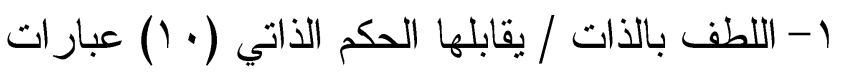

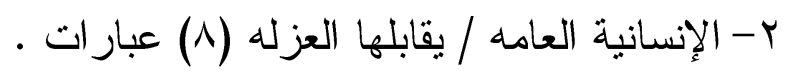

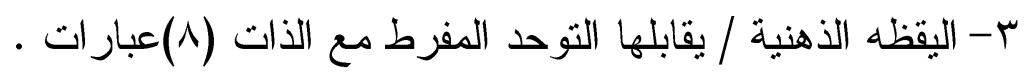

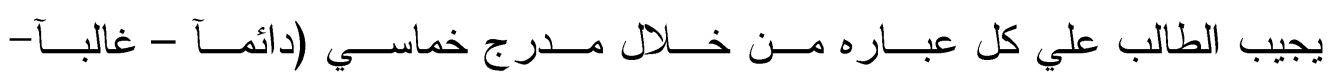

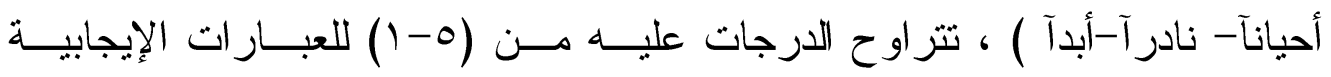

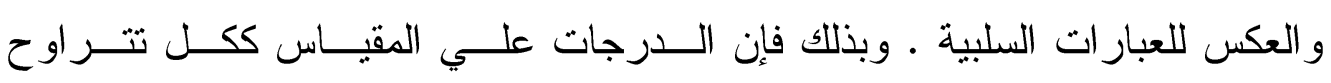

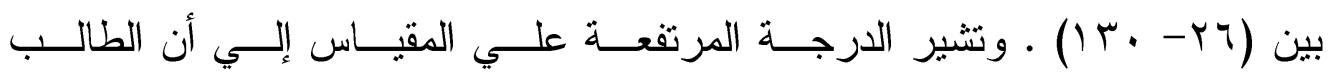

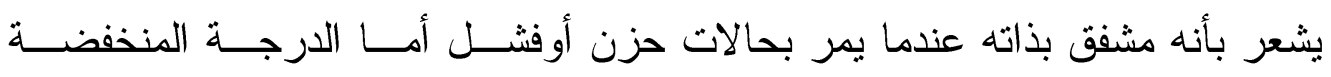

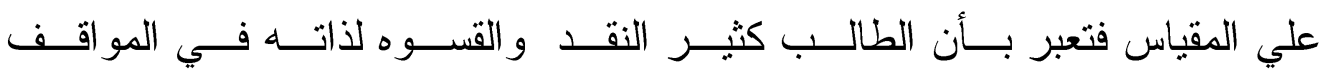

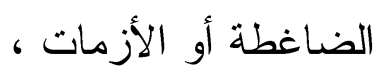
الخصائص السيكومترية للمقياس :

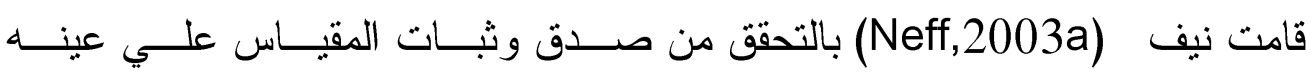

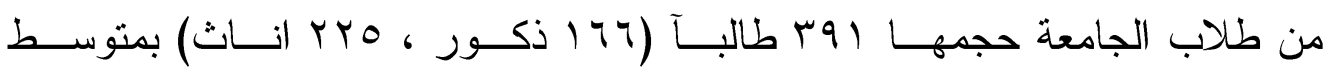

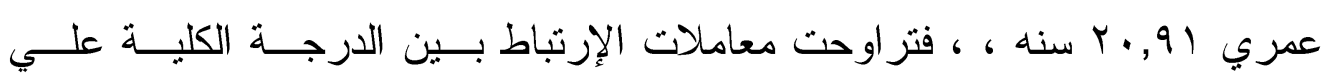

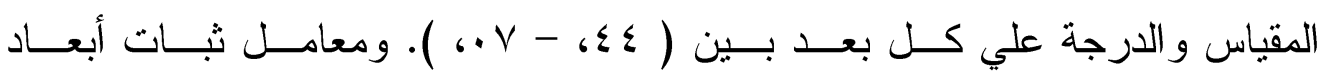

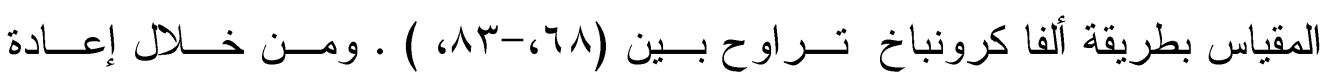

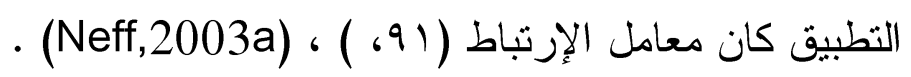

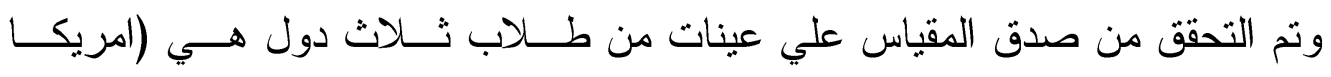

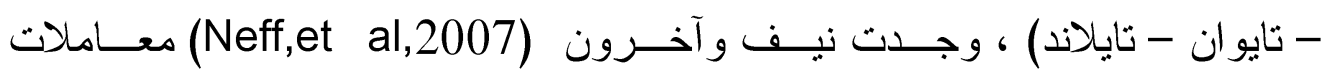

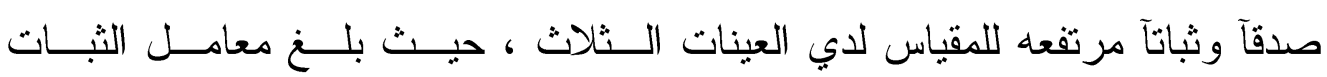




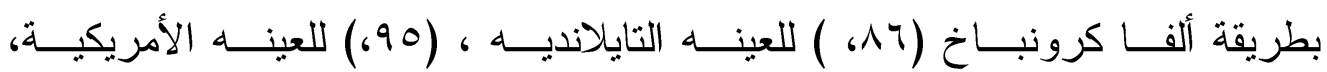

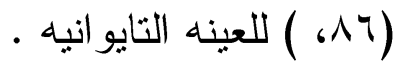

حساب الكفاعة السيكومترية للمقياس في الاراسة الحانه لائة

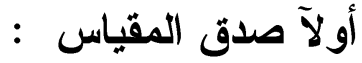

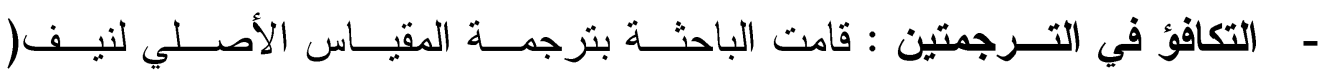

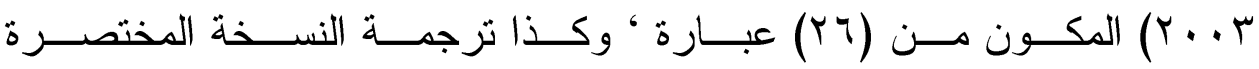

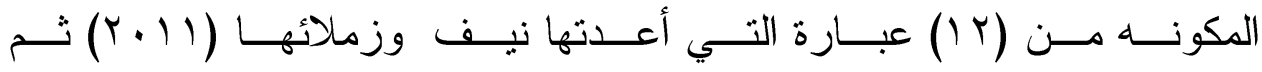

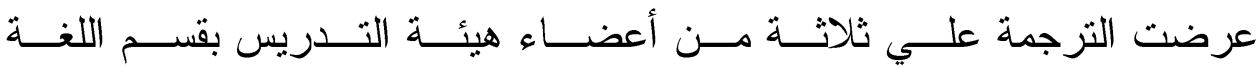

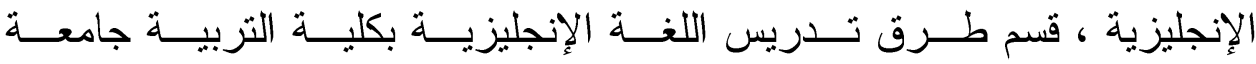

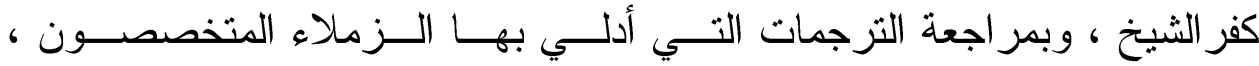

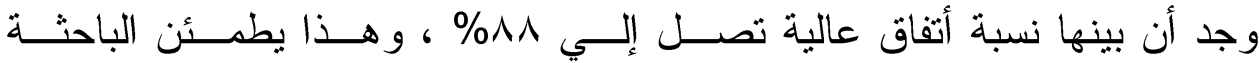

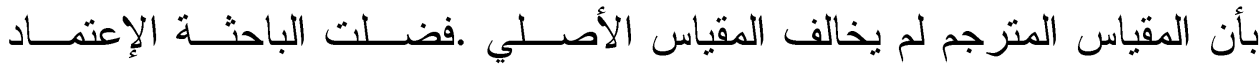

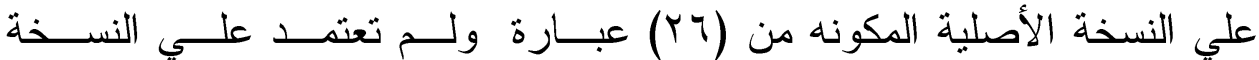

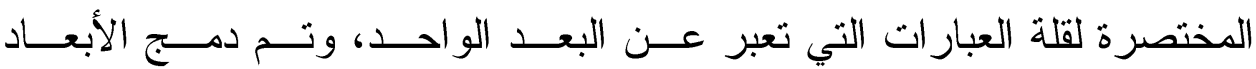

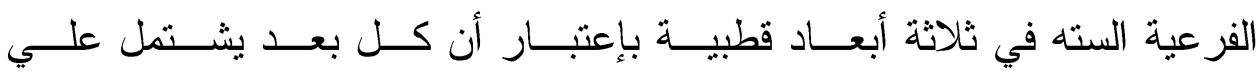

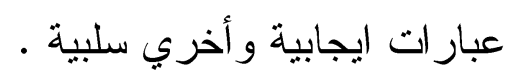
البعد الأول: اللطف بالذات :يتضمن توجيـهـ الفـرد مشـــاعر اللطــف و الــــف نحو الذات بدلآ من نقدها بصر امه شديدة ، وذلك مسـن خــلال (• () عبـارات

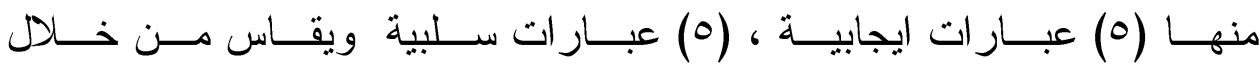

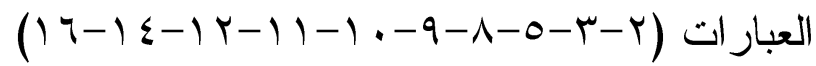

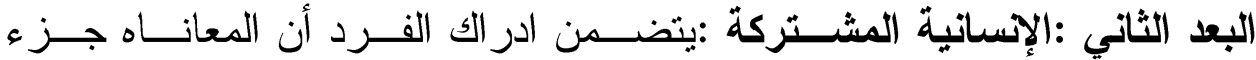

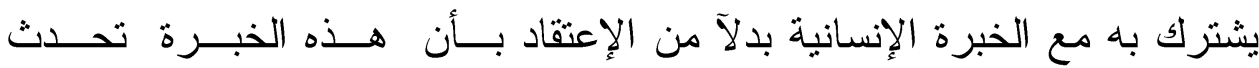

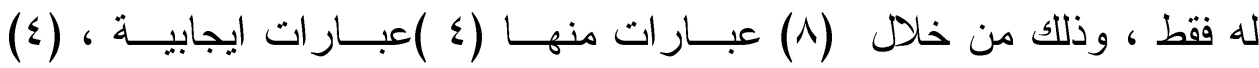

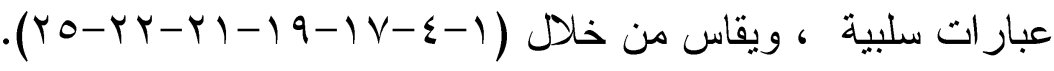
البعد الثالث : اليقظة الذهنية : يعنــي تحمـلـل الفــرد الخبـرة المؤلمــهـ مــن

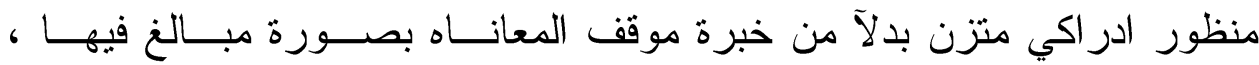




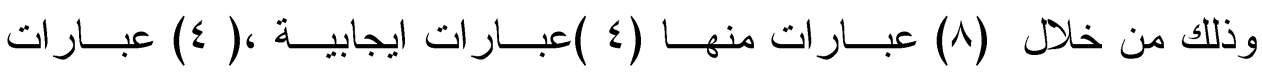

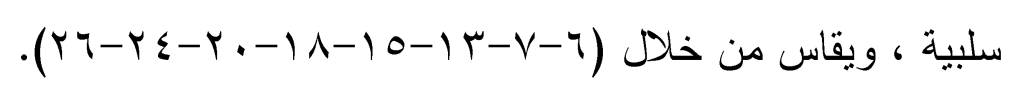

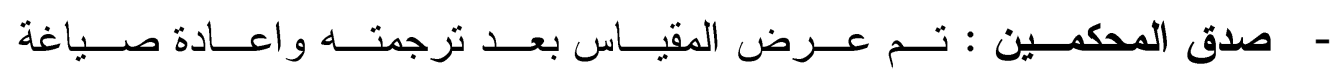

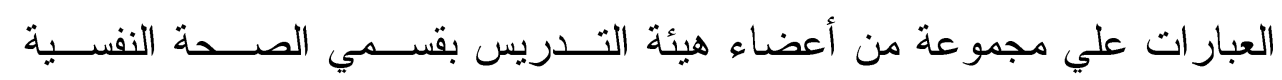

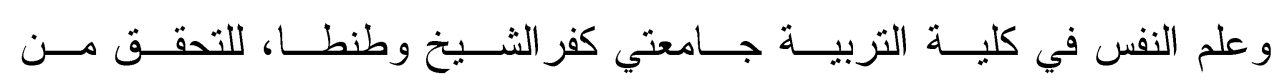

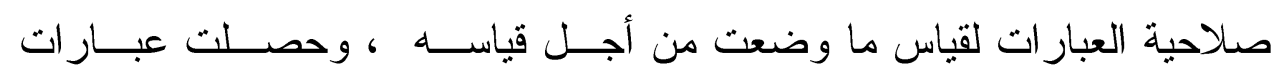

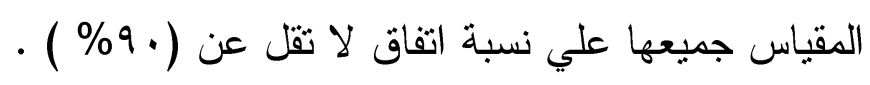

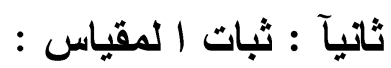

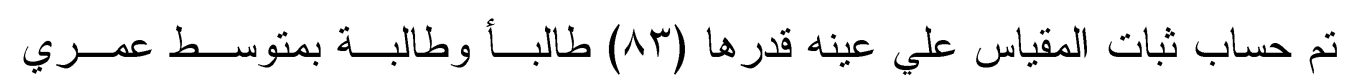

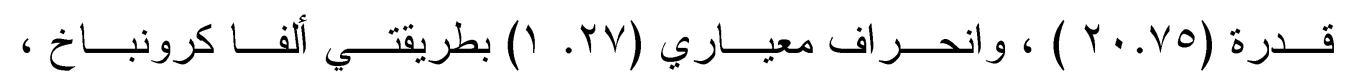

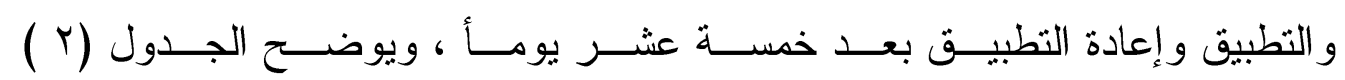
التالي قيم معاملات الثبات للمقياس و أبعاده

\begin{tabular}{|c|c|c|}
\hline \multicolumn{3}{|c|}{ جلول(r) دعاملات الثبات لدقياس الثفقه بالذات ( أبعاد - درجة كلبة ) } \\
\hline التطبيق و إعادة التطبيق & معامل ألفا كرونباخ & أبعاد المقياس \\
\hline$\cdot, 70$ & $\cdot, 74$ & اللطف بالذات / الحكم الذاتي \\
\hline$\cdot, \mathrm{TV}$ & $\cdot, \mathrm{V})$ & الإنسانية المثتركة / العزلة \\
\hline . & $\cdot, 90$ & اليفظة الذهنية / التوحد المفرط \\
\hline$\cdot, \mathrm{VV}$ & $\cdot, \mathrm{V} 0$ & اللارجة الكلية \\
\hline
\end{tabular}

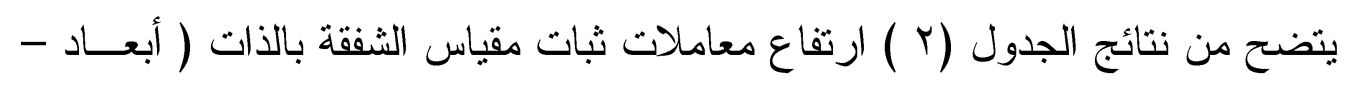

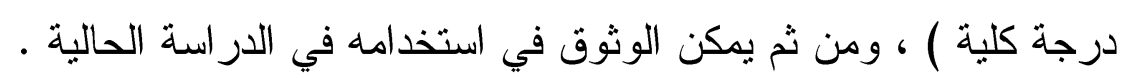

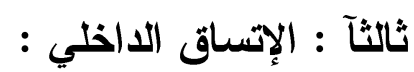
تم حساب معامل الإرتباط بين مفردات كل بعد و الدرجة الكلية لهذا البعد بعد حـذف تهاتف

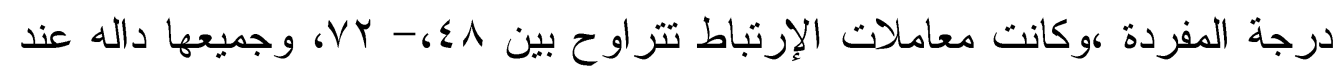

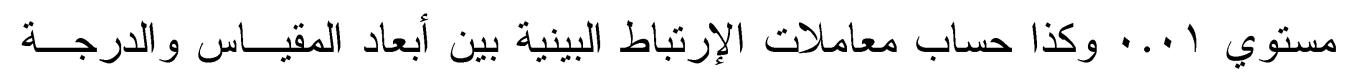

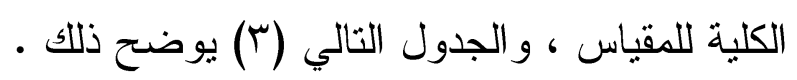


جدول (T) معاملات الإرتباط البينية بين الأبعاد والدرجة الكلية لمقياس الشققة

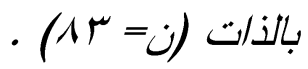

\begin{tabular}{|c|c|c|c|}
\hline التيقظة الذهنية / المفرط & الإنسانية المشتركة / العزلة & اللطف بالذات / الحكم & الأبعاد \\
\hline & & - & اللطف بالذات/ الحكم الذاتي \\
\hline & - & $\cdot$, Or & الإنسانية المشتركة / العزلة \\
\hline - & $\cdot, 00$ & $\cdot, \Delta \wedge$ & التيقة الذهنيه / المفرط \\
\hline$\cdot, V Y$ & ,99 & $\cdot, T V$ & الدرجة الكلية \\
\hline
\end{tabular}

يتضح من الجدول (ب) السابق أن جميع معاملات الإرتبـاط دالــة عنــــ مســتوي ( ( . . . ) مما بدل علي اتساق وارتباط أبعاد مقياس الشفقة بالذات ببعضــها، و هــــا يطمئن الباحثة لإستخدامه في الدر اسة الحالية .

ثsychological Resilience Scal : ثانيآ مقياس الصمود النفسي صمدت الباحثة المقياس بعد الإطلاع علي التراث الـذي تتــاول مفهـوم الصــمود

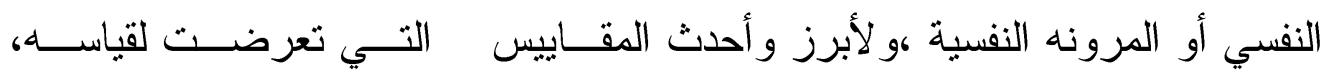

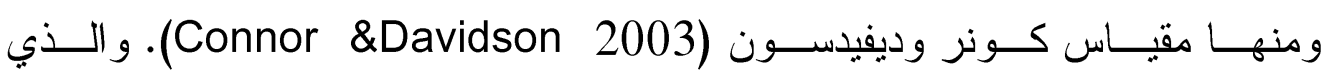

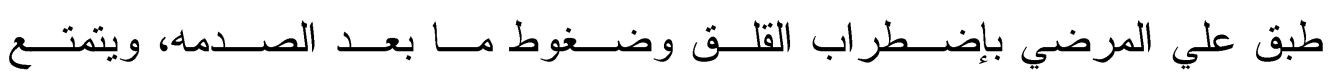
المقياس بخصائص سيكومترية جيده، وأظهـر التحليـل العــاملي خمسس عوامـلـل هي الكفاءة الثخصية و التماسك، التقة فـي الـذذات و التشـــامح، التقبــلـ الإيجــابي للتغير وعلاقات آمنه، الضبط أو التحكم، التأثير ات الروحية و الدينية .

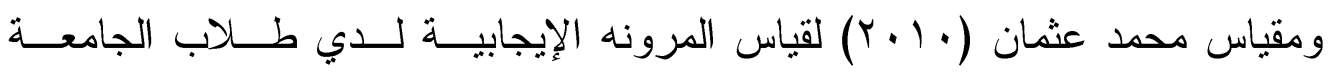

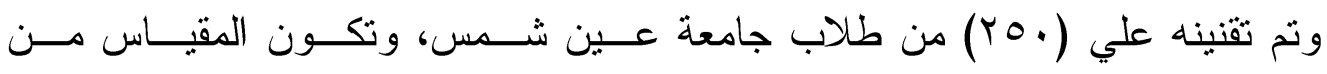

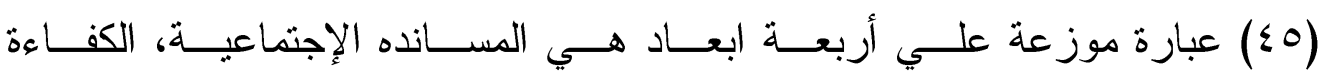

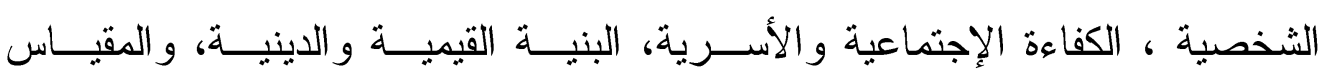
يتمتع بكفاعة سيكومترية جيده .

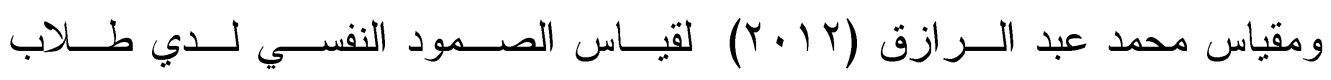

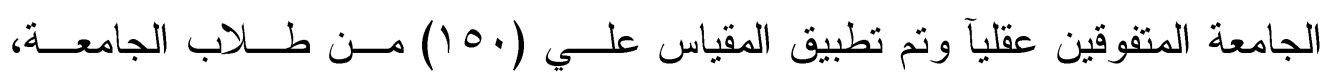

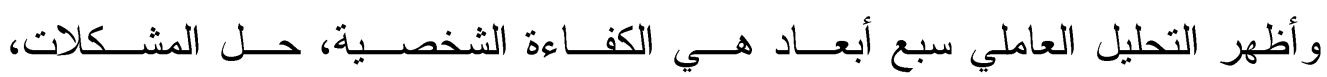




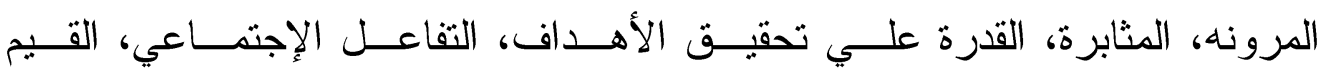

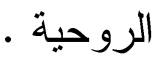

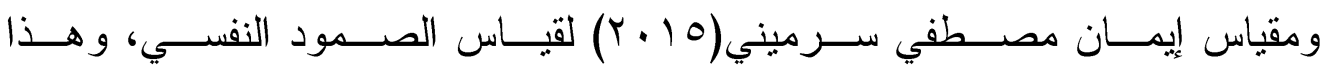

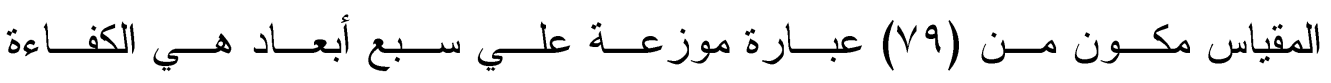

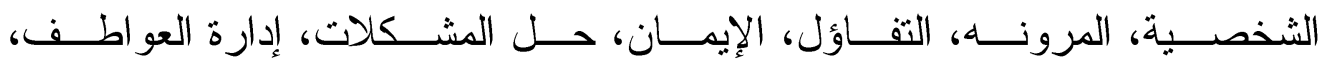

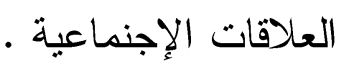

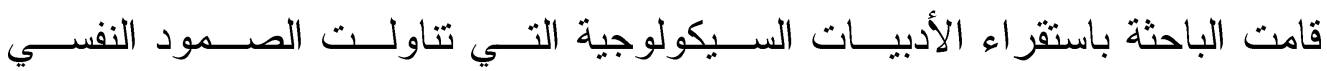

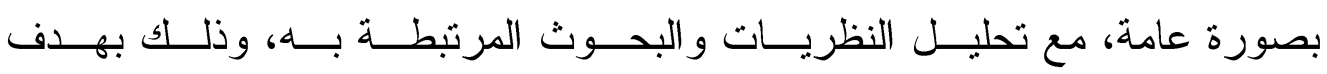

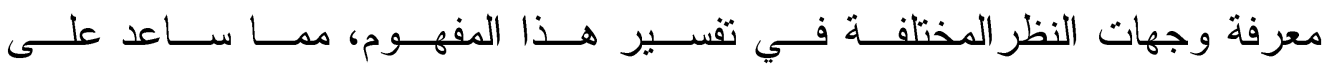
استخلاص مجالاته ومكوناته وتحديد التعريف الاجر ائي.

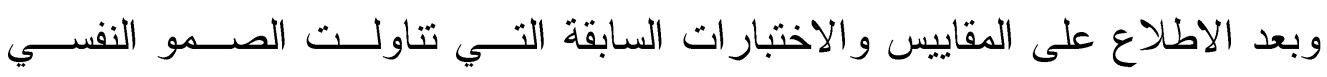

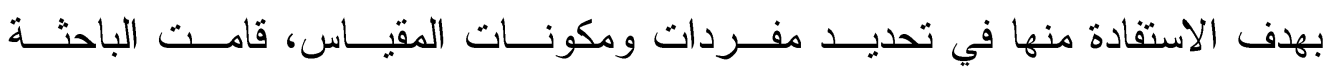

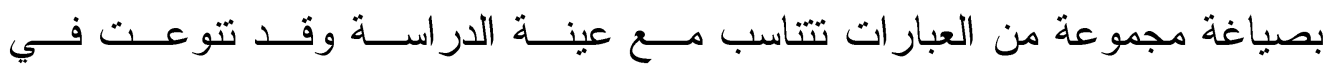
الصياغة بين الإيجاب و السلب.

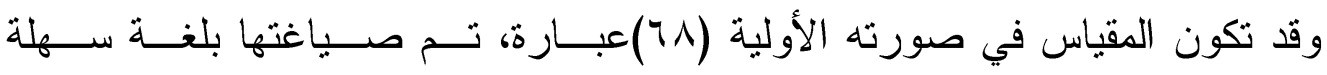

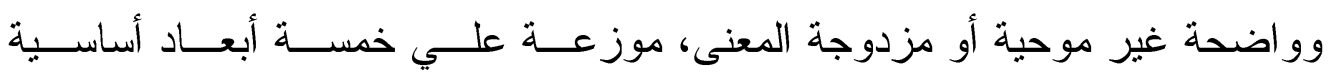

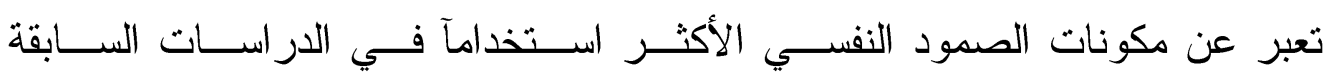

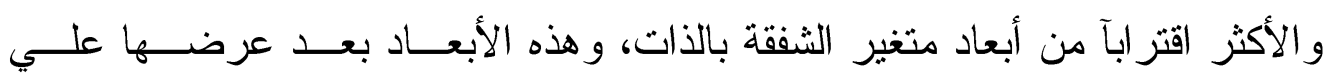

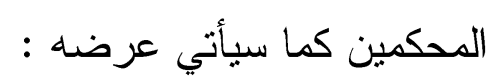

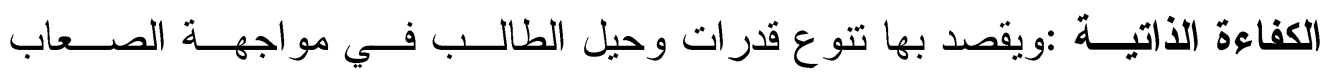

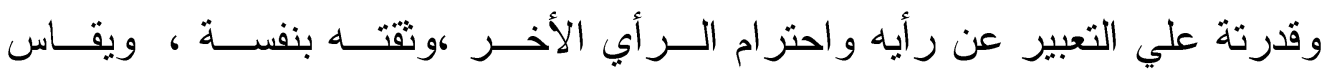

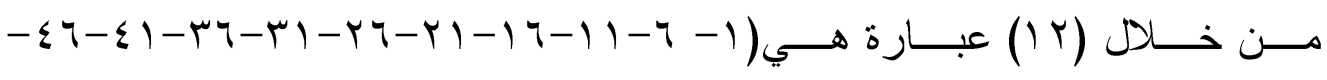
$.07-0)$

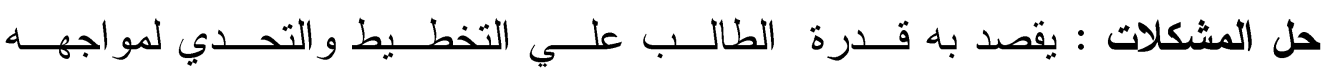

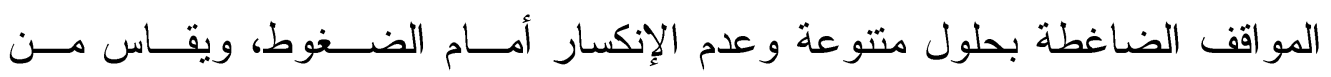


خـــل . (OV

المرونه : يقصد بها قدرة الطالب علي ســـولة التكيـف مــع المواقـف الجديــدة

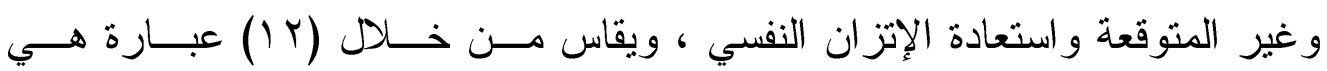

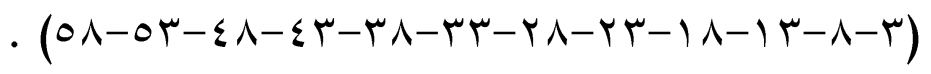

المثابرة وتحقيق الهدف : يقصد بـــه اصــر ار الطالب علـي متابعـــة أداء المهــام

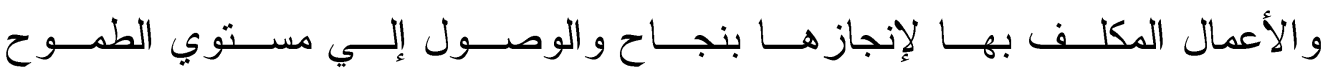

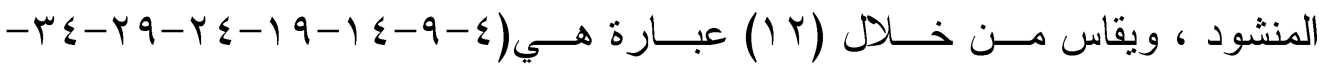
.$(09-0 \varepsilon-\varepsilon q-\varepsilon \varepsilon-4 q$

الكفاعة الإجنماعية والوجدانية :يقصد بـــهـ قـدرة الطالـبـ علــي إقامــة علاقــات

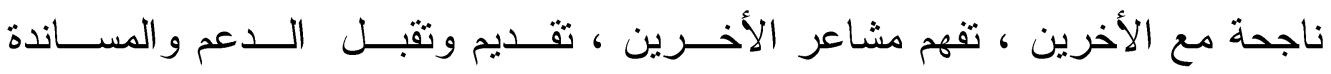

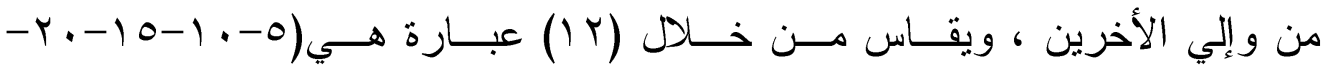
. ( .

حساب الكفاعة السيكومترية لمقياس الصمود النفسي : أولآ الصدق :

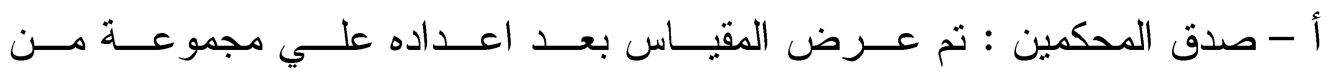
أعضاء هيئة التدريس بقسمي الصحة النفسـية و علــم الــفس فــي كليــة التربيــة

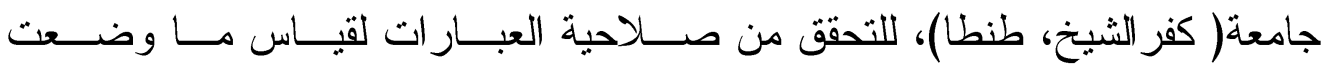

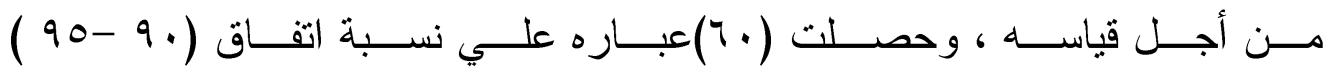

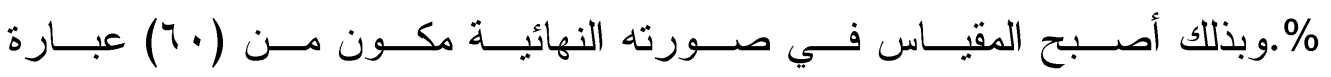

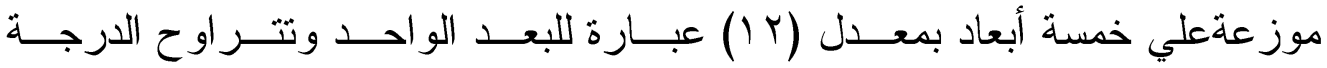

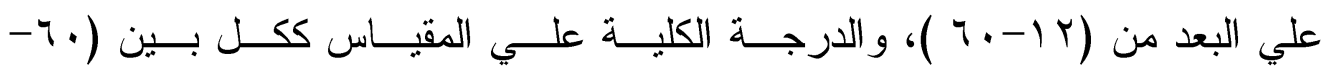

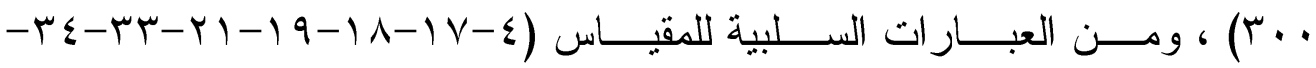

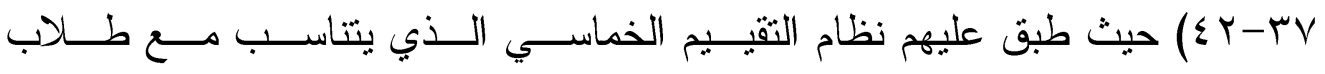

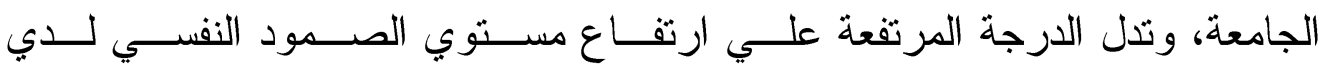
الطالب الجامعي و العكس صحيح . 
ب- صدق المقارنه الطرفية : تم حساب الفروق بين فئتي الأرباعي الأعلي و الإرباعي الأدني في الدرجات علي

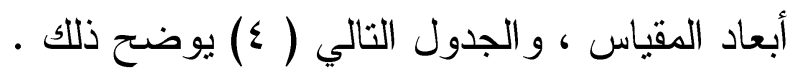

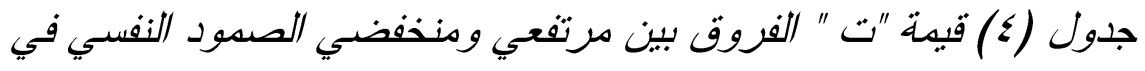
درجات الأبعاد

\begin{tabular}{|c|c|c|c|c|c|c|}
\hline \multirow[t]{2}{*}{ الدلالة } & \multirow[t]{2}{*}{ قيمة ت } & \multicolumn{2}{|c|}{ منذفضى الصمود ن ب r ب } & \multicolumn{2}{|c|}{ مرتفعى الصمود ن ا } & \multirow[t]{2}{*}{ الابعاد } \\
\hline & & $\varepsilon$ & p & $\varepsilon$ & 5 & \\
\hline$\cdot 6 \cdot 1$ & $\varepsilon, 0 Y$ & r.lV & $1+69$ & $r 6.9$ & $11_{6} 10$ & الكفاعة الذاتية \\
\hline$\cdots 1$ & O.VV & T.rT & $9.0 Y$ & $r, 0 \Lambda$ & 10.70 & القدرة علاتي حل \\
\hline .61 & $\varepsilon_{6}$. & $r, r r$ & $1.61 \mathrm{~V}$ & 9.91 & $1 \leq 6 . \Lambda$. & المرونهـ \\
\hline..+1 & $\varepsilon_{6} \wedge$. & r.r. & 116.0 & r.90 & $10 . \mathrm{VO}$ & الألثابرة وتحقيق \\
\hline .61 & $\varepsilon_{6 \wedge \Lambda}$ & r.o. & TY..0 & r.91 & $17.0 Y$ & الكفاعة الإجتماعية \\
\hline
\end{tabular}

ثانيآ : ثبات المقياس :

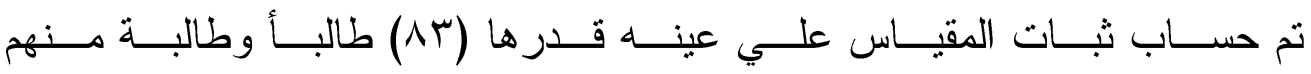

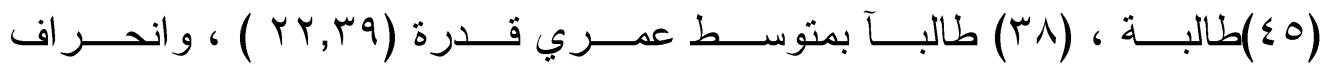

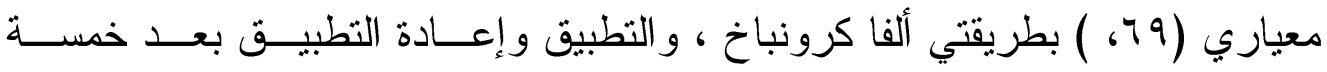

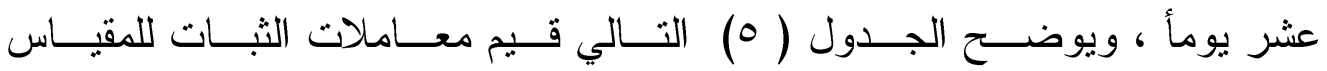
و وأبعاده .

جدول (0) معاملات الثبات لكقياس الصدود النفسي ( أبعاد - درجة كلية ).

\begin{tabular}{|c|c|c|}
\hline التطبيق وإعادة التطبيق & معامل ألفا كرونباخ & أبعاد المقياس \\
\hline$\cdot, \mathrm{v4}$ & $\cdot \pi$ & الكفاءة الذاتية \\
\hline., 70 & $\cdot, 0 \wedge$ & القلرة على حل المشكلات \\
\hline$\cdot, \wedge \top$ &., 70 & المرونه \\
\hline$\cdot, 70$ & $\cdot, 90$ & القدرة علي المثابرة وتحقيق \\
\hline$\cdot, \uparrow \Lambda$ &., 70 & الكفاءة الإجتماعية والإنفعالية \\
\hline$\cdot, \mathrm{V}_{\mathrm{O}}$ & $\cdot, \mathrm{VN}$ & الالرجة الكلية \\
\hline
\end{tabular}

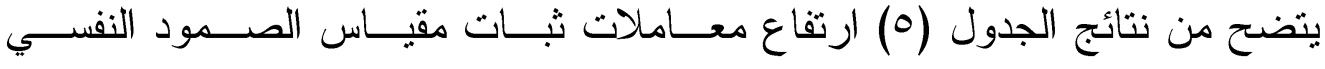

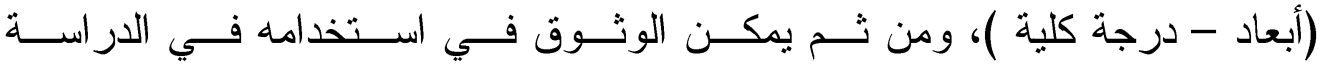


ثالثآ : الإتساق الداخلي :

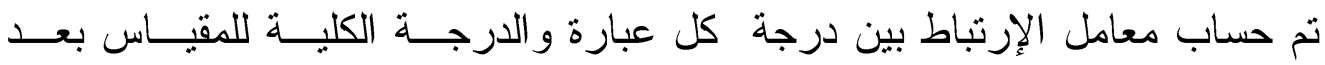

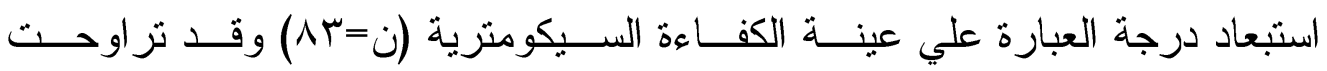

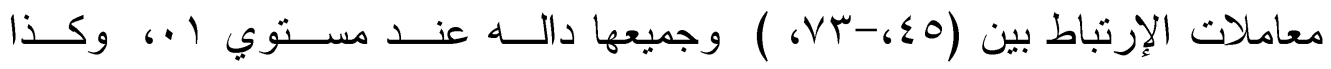

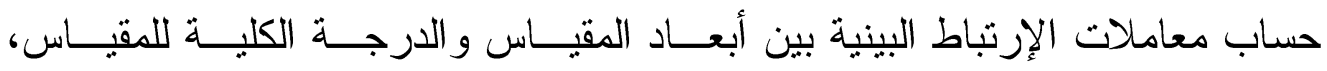

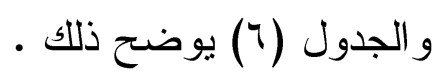
جدول (آ) معاملات الإرتباط البينية بين الأبعاد والدرجة الكلبة لدقياس الصدود النفسي لوني

\begin{tabular}{|c|c|c|c|c|c|}
\hline \multicolumn{6}{|c|}{ (ن) $(\Lambda \mu)$} \\
\hline الكفاءة الإجتماعية & القارة عقيق اللهذفثابرة & المرونه & حل المشرة علاتي & الألكاية & الأبعاد \\
\hline & & & & - & الكفاءة الذاتية \\
\hline & & & - &., 07 & القدرة علي حل \\
\hline & & - &., 07 &., 01 & المرونه \\
\hline & - & $\cdot, 71$ & $\cdot, 71$ & $\cdot, 7 r$ & المثابرة وتحقيق القارة عليق \\
\hline- & $\cdot, \Delta V$ & $\cdot, O Y$ & $\cdot, 7 \xi$ & $\cdot, 70$ & الكفاعة الإجتماعية \\
\hline$\cdot, \mathrm{V} r$ & $\cdot, 97$ & $\cdot, V r$ & $\cdot, \mathrm{VI}$ & $\cdot, V Y$ & اللارجة الكلية \\
\hline
\end{tabular}

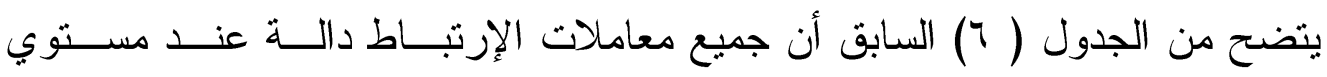

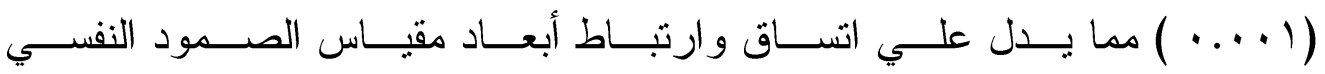

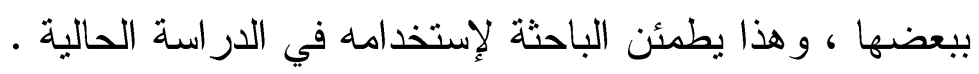

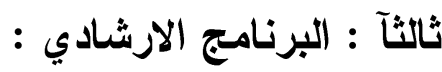

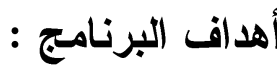

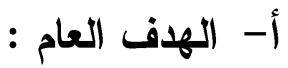

يهدف البرنامج إلي تدريب مجموعة من شباب الجامعة علي تحسين مكونات الثفقة

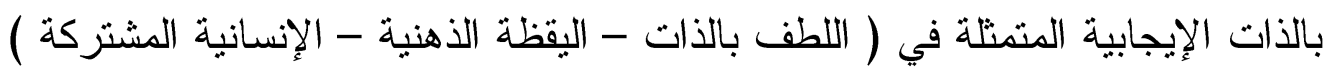
وتخفيف المكونات السلبية المتمنلة في (كثرة لوم الذات - العزلة و الإفر اط في التوحد

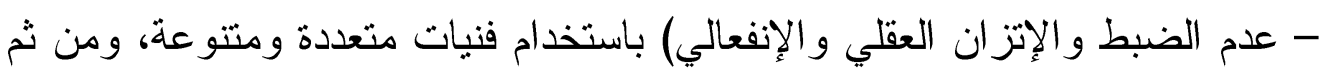
تحسن مستوي الصمود النفسي لدي أفر اد العينة . 


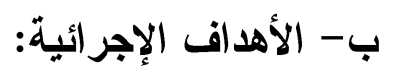

1- تتمية المسؤولية الثخصية و الاجتماعية اهتماما وفهما ومشاركة. Y- تتمية مفهوم الذات الإيجابي لدى عينة الدراسة. r- تدريب عينة الدراسة على الحوار الذاتي وتتمية مهار ات الات ضبط الذابه الذات.

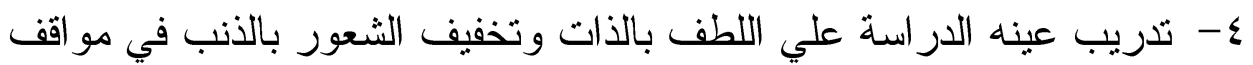

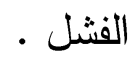

0- تتمية مهار ات الاسترخاء وحل المشكلات و اتخاذ القرارات بأساليب علمية. צ- تدريب عينة الدراسة على الوعي الذهني في حل المشكلات و المثابره على حلها.

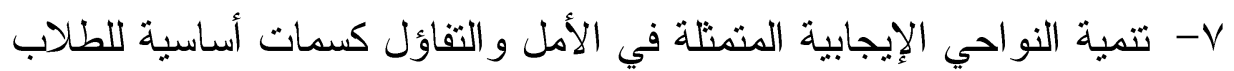
المشفقين بذو اتهم و الصامدين نفسيا.

1- تتمية مهار ات التو اصل مع الآخرين بأسلوب الحوار و المناقشة و الإقناع. 9- تدريب عينة الدراسة علي النعبير عن أنفسهم وذواتهم مع إكسابهم الثقة بالنفس.

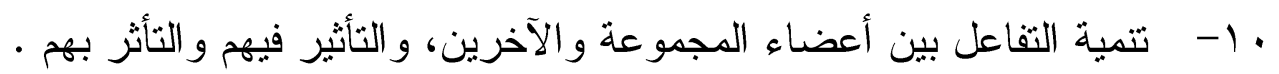
11- التمية القيم الروحية والأخلاقية المتمثلة في مبادئ الدين و الإيمان. أهمية البرنامج: تتمثل الأهية في عدة نقاط تظهر في الجوانب التالية :

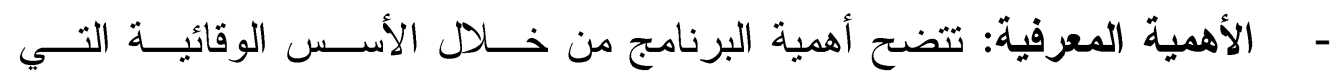

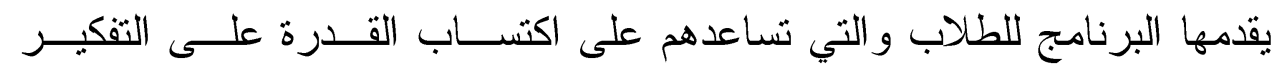
السليم و الحوار الذاتي وضبط الذات. - الأهمية الوجدانية: تكمن هذه الأهميــة فــي تــدريب عينــة الدراســة علــي

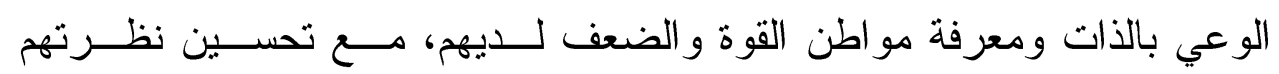
للحياه وجعلها إيجابية. - ـ الأهمية السلوكية: تتمثل هذه الأهمية في تتميــة مكونــات ومهــارات الثــفقة

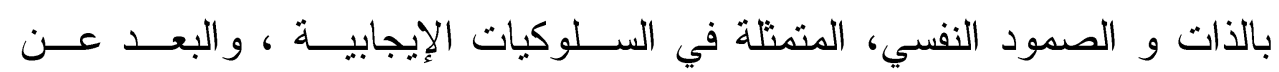

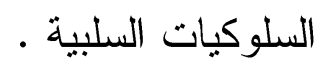


الأساس النظري للبرنامج ومصادره :

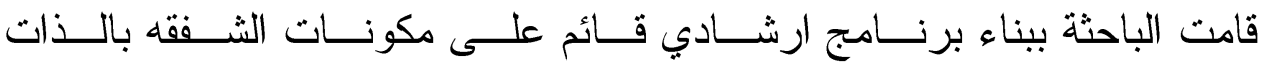

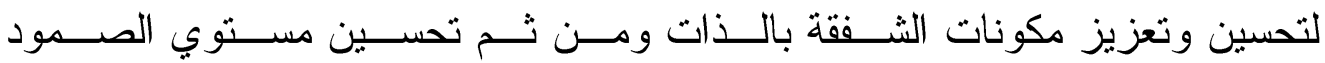
النفسي لدي طلاب الجامعة .

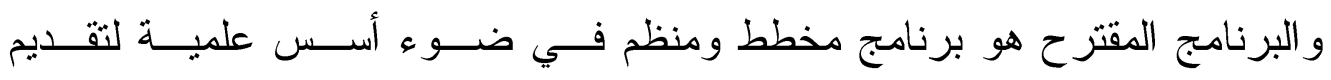

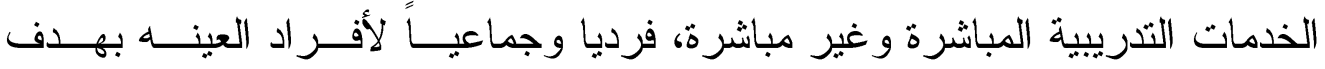

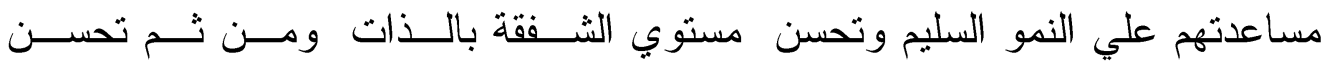

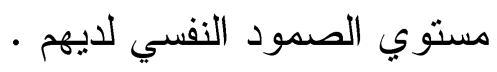

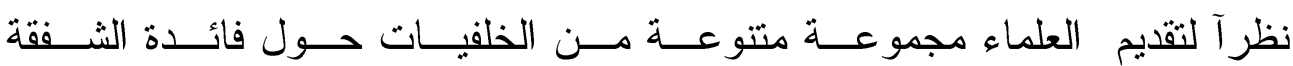

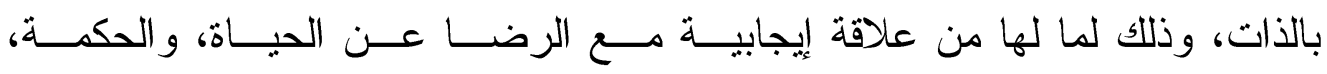

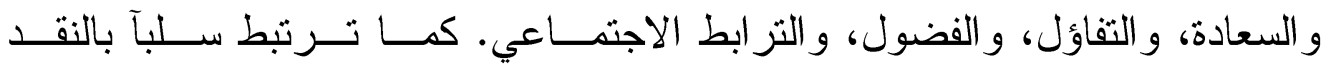

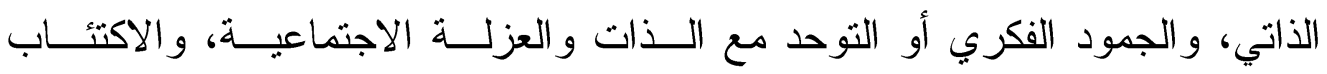
و القلق، والاجتزار الفكري(Neff et al,2007)

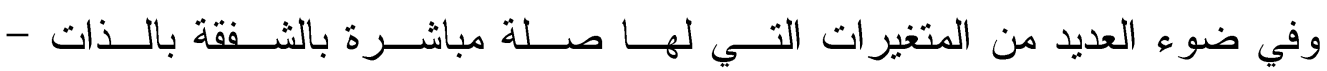

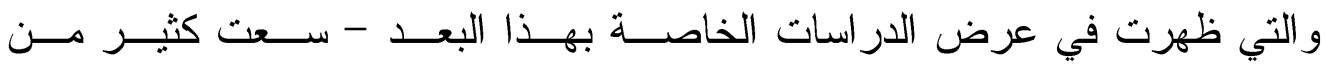

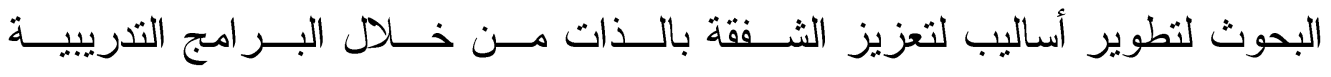

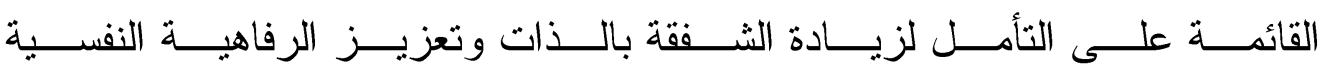
Barnard\& Curry,2011,Karakasidou\&Stalikas,2017,)

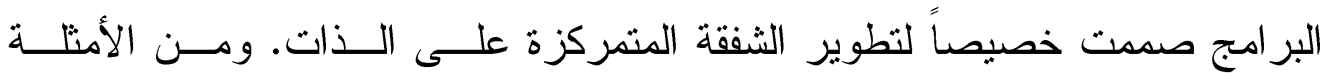

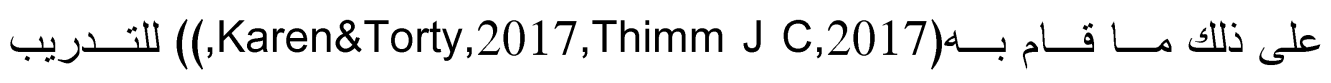

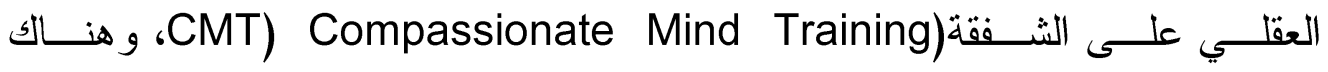

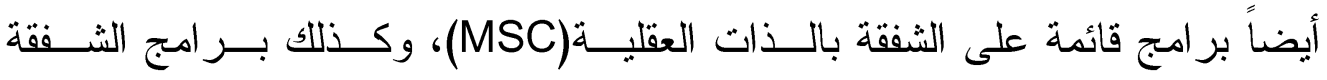

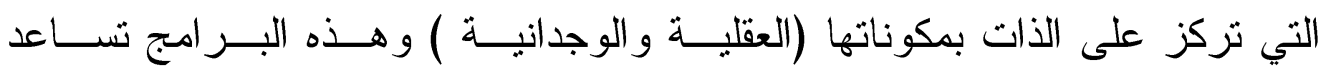

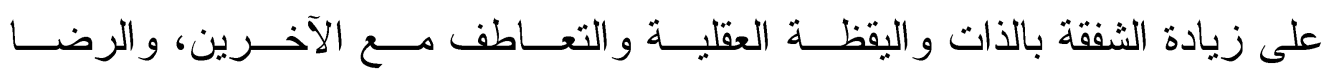

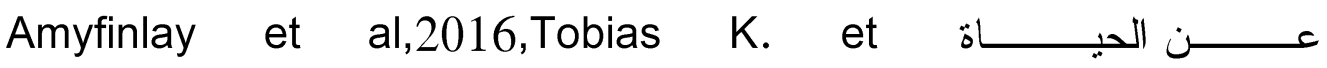
.(al,2017,Mantelou et al,2017) 


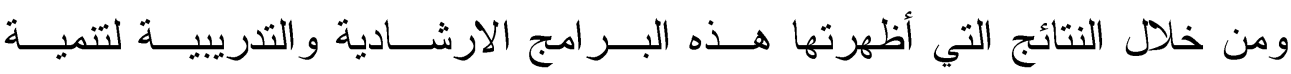

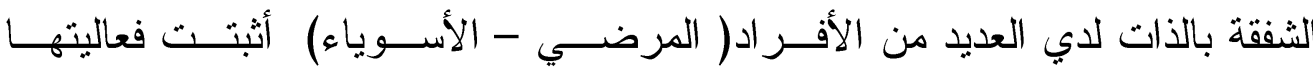

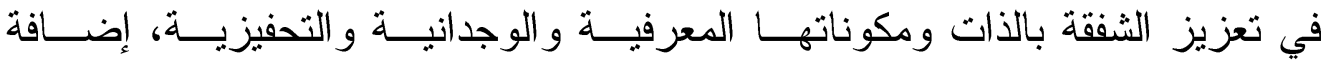

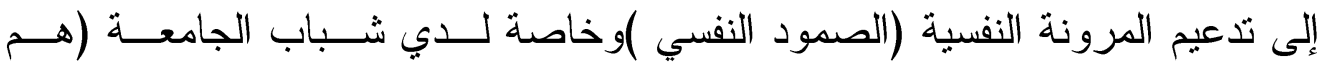

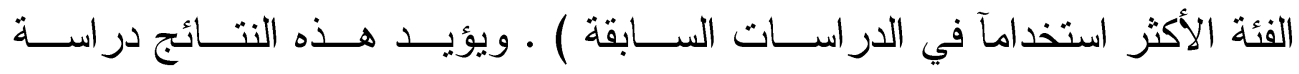

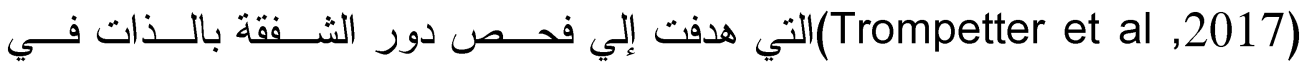
تحقيق الصحة العقلية وتخفيف المرض النفسـي ، و اكتشــاف دور الثــفقة بالـــات

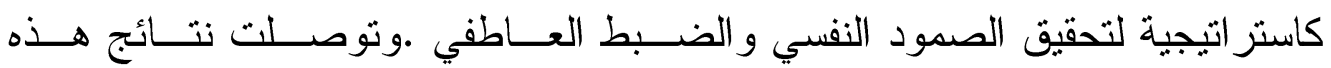

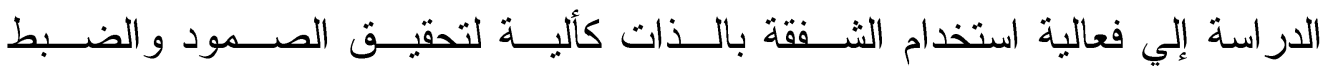

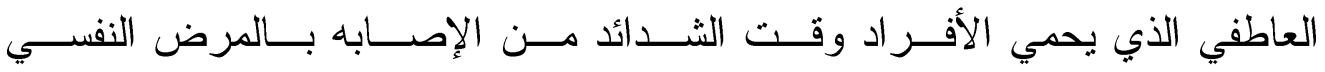

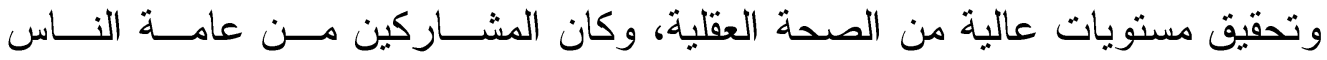

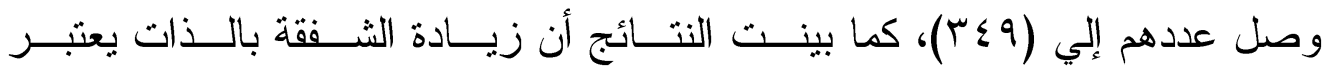

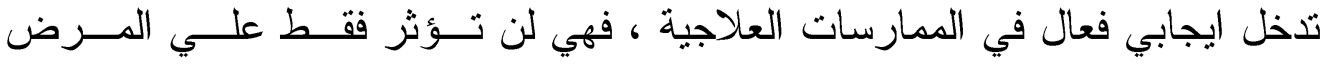

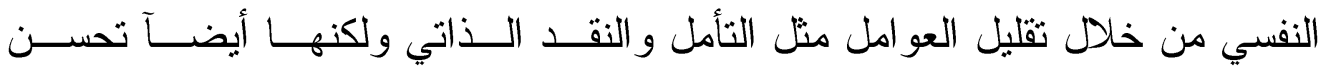

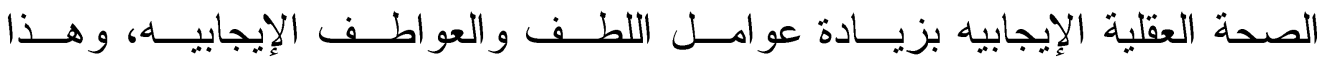
ربما يقلل من المخاطر المستقبلية للمرض الإيهابه برادة النفسي . ودر اســة (Bluth K. \&Eisenlohr-Moul T., 2017 (ســتخدام الثــفقة بالذات كمدخل لتحسين مستوي الثفقة بالذات و اليقظـــة العقليـــة والحالــــة العاطفيـــة لاي المر اهقين " هدفت الدراسة إلي إختبار فعالية البرنــامج القـائم علــي الثــفقة

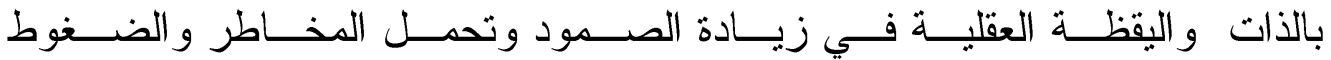

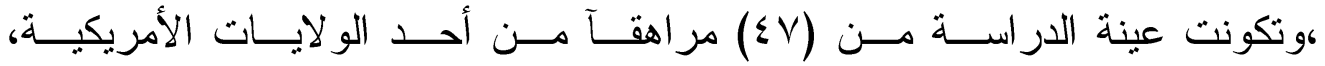

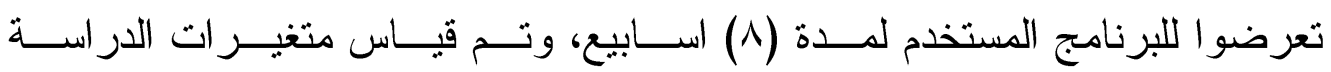

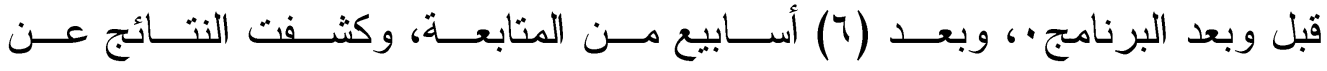

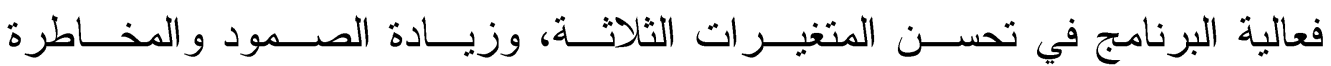
الإيجابيه لدي أفر اد العينه . 


\section{1}

وقد تم تسليط الضوء على الصــمود النفسـي باعتبــاره أســاس الصـــة النفسـية و الرفاهية، النفسية و التكيف مــع المطالــب الحياتيــة، و إعـادة تثــكيل المصـــادر

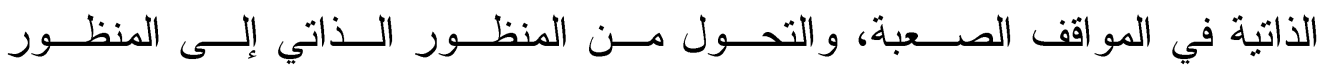

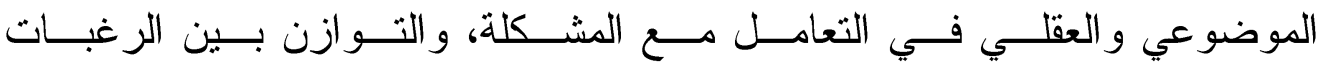
و الاحتباجات المتصار عة في حياة الطالب الجامعي .

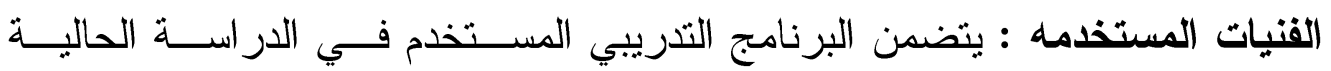

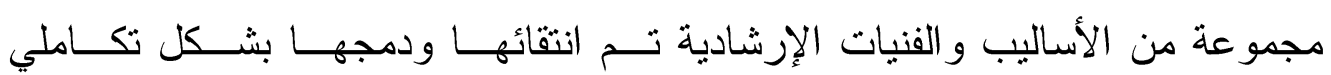
لخدمة أهداف البرنامج ومن هذه الفنيات:

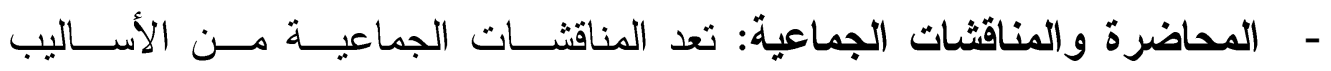

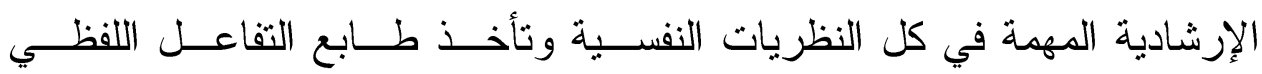

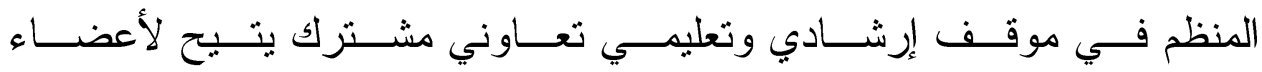
المجموعة الإرشادية فرصة للتعبير عن ذو اتهم ومشكلاتهم.

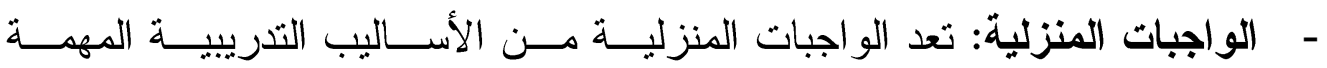

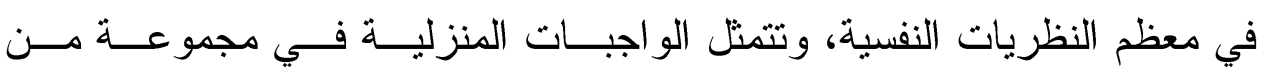

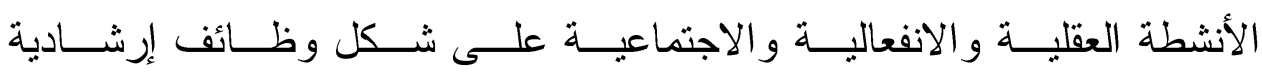

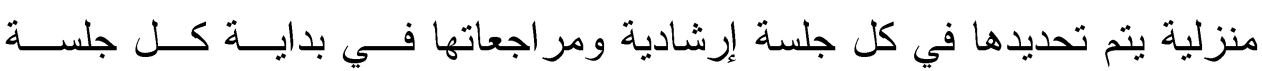
لتحقيق التقدم في العملية الإرشادية.

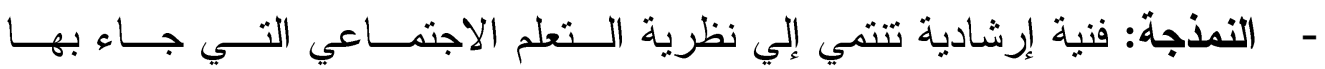

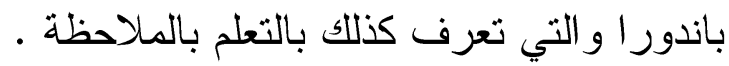

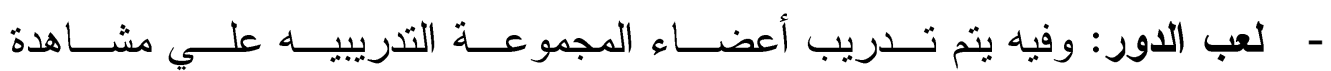

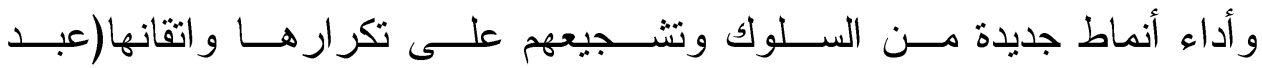

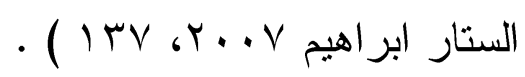

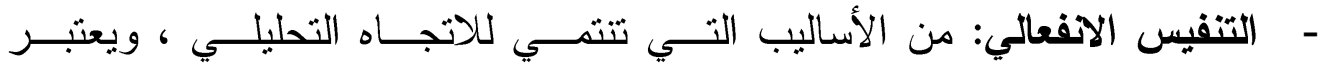

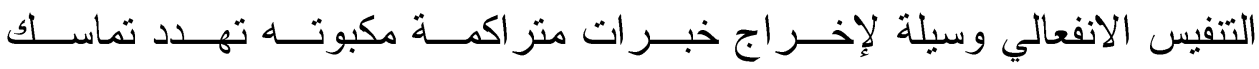

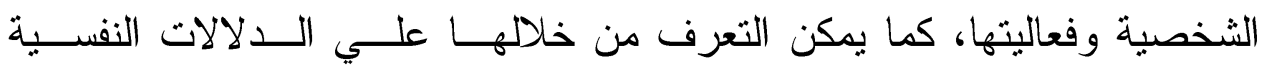
للمخرجات اللفظية وغير اللفظية والتي تشكل أهمية لتحقيق الأهداف. 


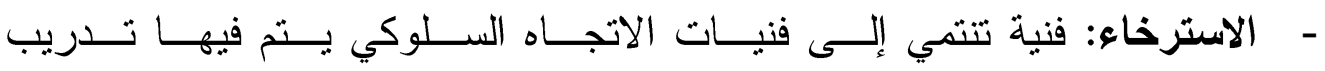

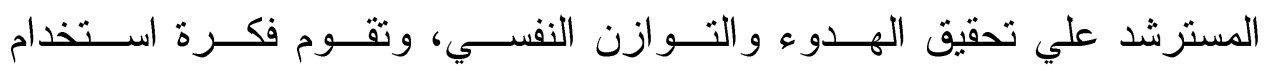

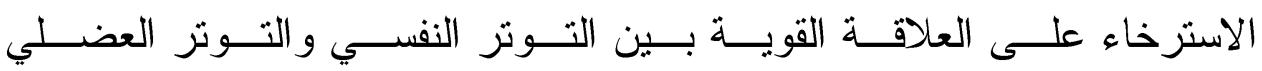

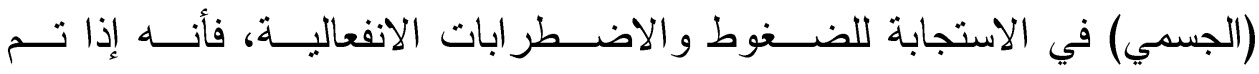

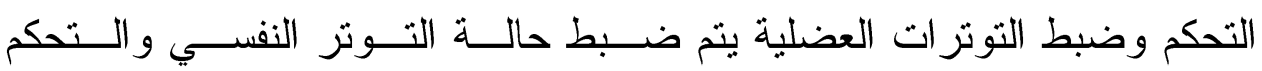
في المشكلات التي ترتبط بالتوتر النفسي في المواقف الضاغطة.

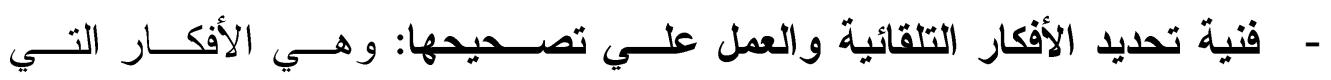
تسبق مباشرة أي انفعال غير سار، وهــى أفكـار غيــر معقولـــة ذات صــفة

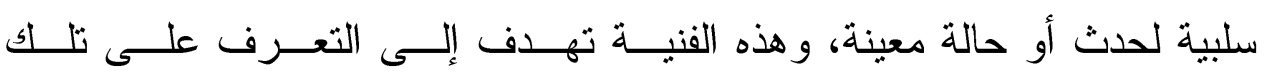
الأفكار ومن ثم تبديلها بأفكار إيجابية تؤدى إلـى نهايــة حسنة.(حســن علـي

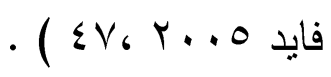

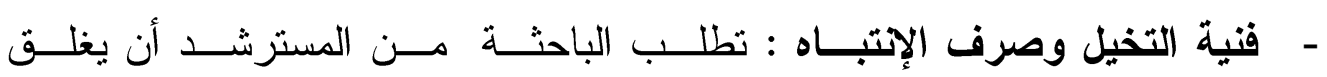

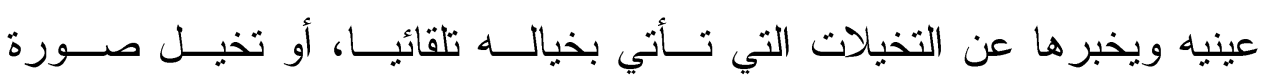

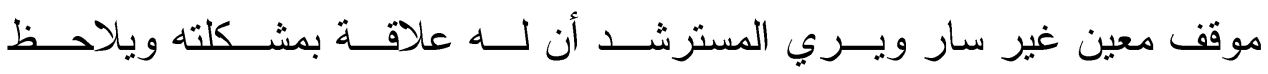

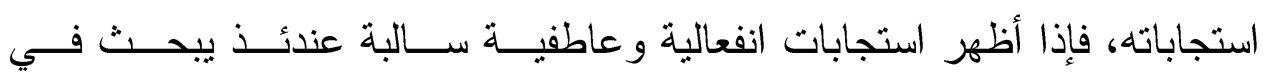

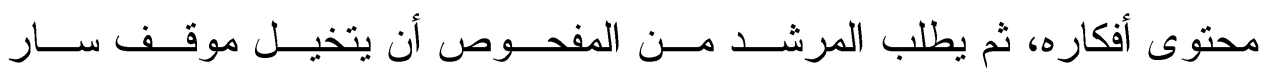

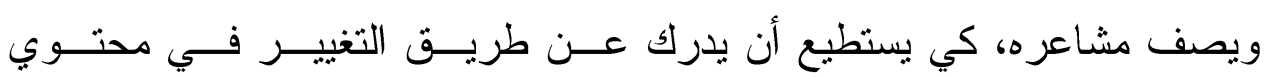
أفكاره التي أثرت في مشاعره، وبالتالي يغير مشاعره إذا غير أفكاره.

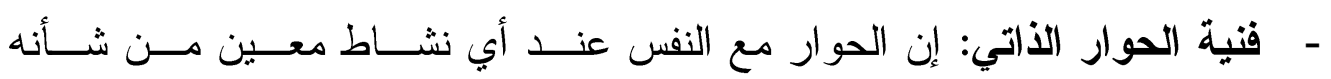

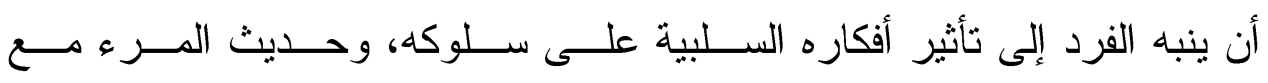

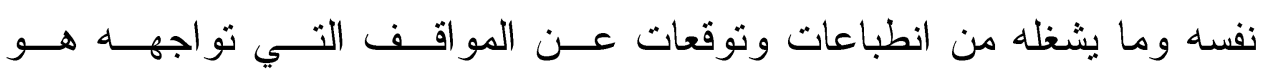
السبب في تفاعله المضطرب، ولهذا بعتمد المعـالج المعرفـي الســلوكي علـي ولي

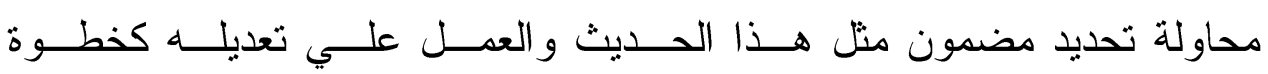
أساسية في مساعدة الفرد للتغلب على اضطر اباته.

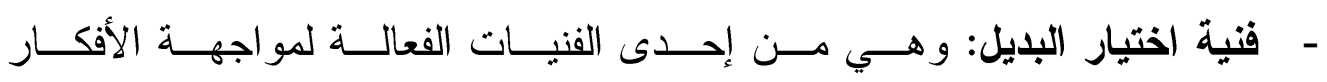

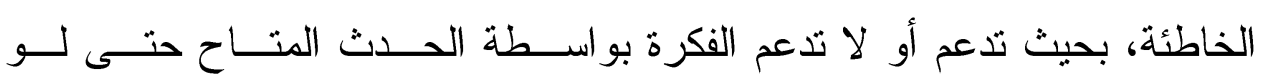


كان هناك بعض التأويلات الأخرى التي تكــون مناســبة بشـــل أكثــر لهـــا

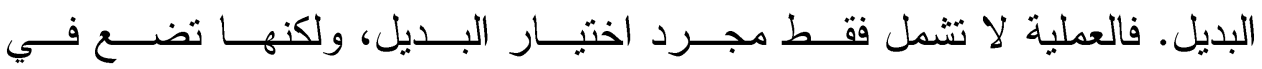

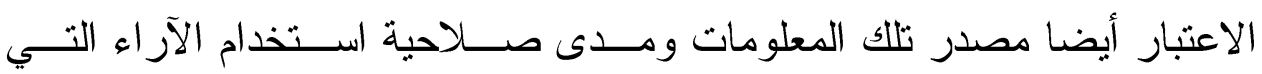

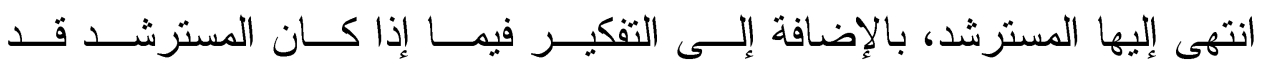

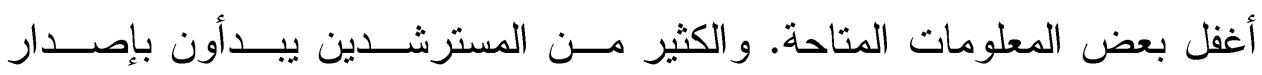

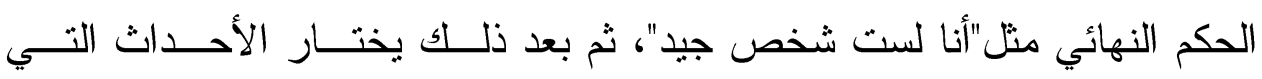
تدعم وجهة نظره و الر أي الذي انتهى إليه.

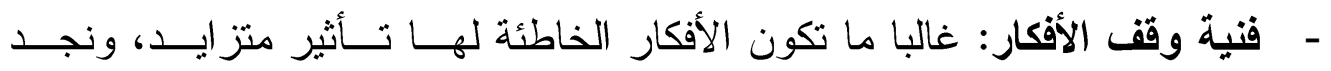

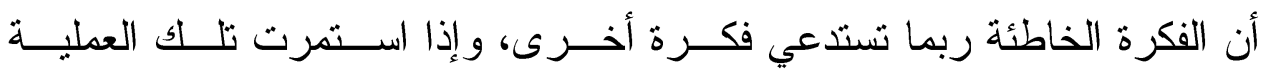

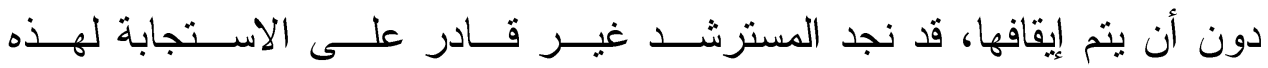

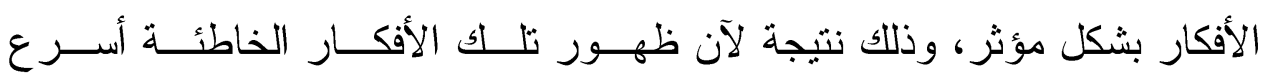

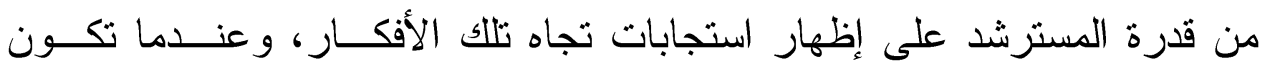

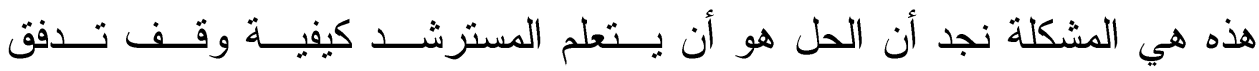

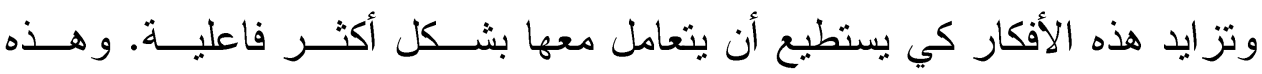

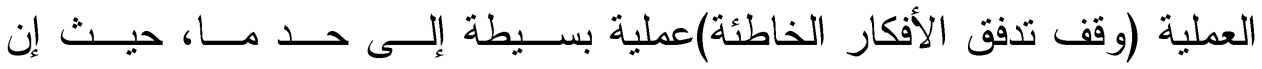

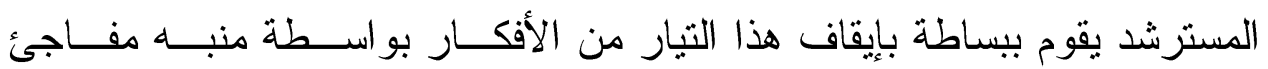

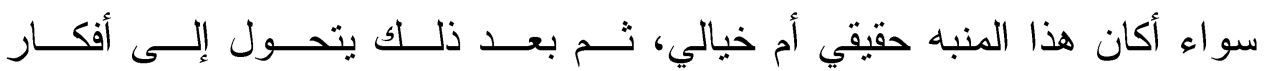

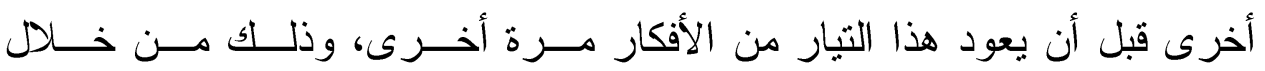

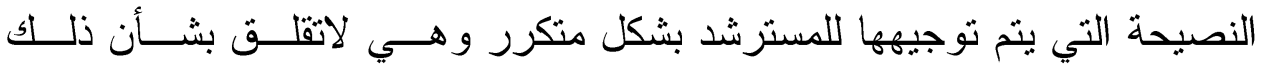

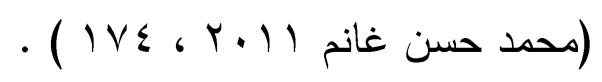

وصف البرنامج وحدوده: يتصف هذا البرنامج ببعض المحددات التالية:

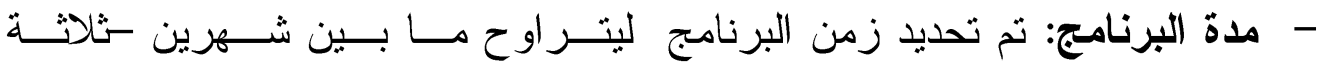

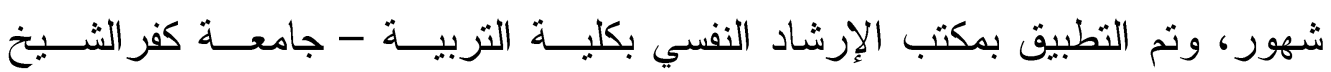

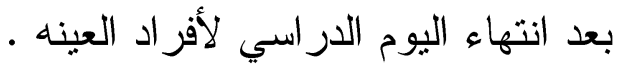

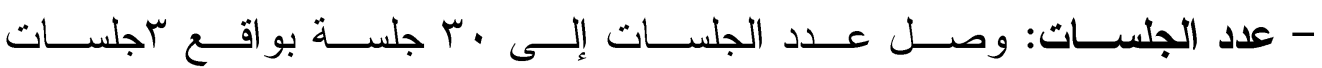
أسبو عباً. 
- مدة الجلسة: تر اوحت مدة الجلسة ما بين ، م الى . ـ دقيقه.

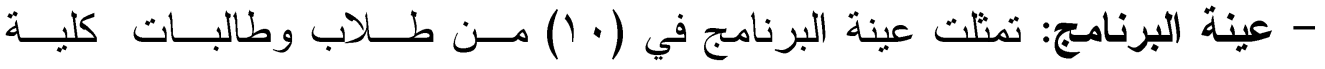
التربية جامعــة كفر الثــيخ مو الجــدول ( V) التــالي يوضــح ملخصــآ لجلســات

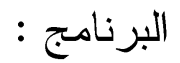

\begin{tabular}{|c|c|c|c|c|}
\hline زلجنة & المستخدمة الفتيات & أهداف الجلسة & عنوان الجلسة & r \\
\hline دقيقة & 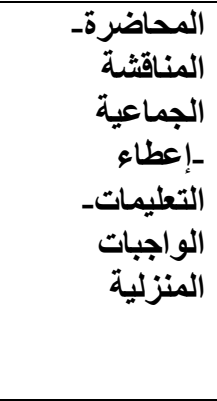 & 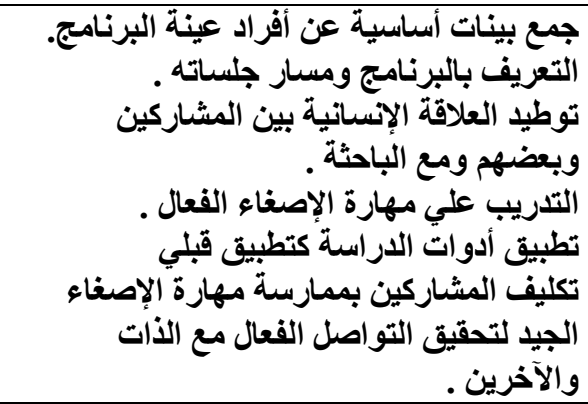 & تلعارف وتمهيد & $r-1$ \\
\hline • r ادقيقة & 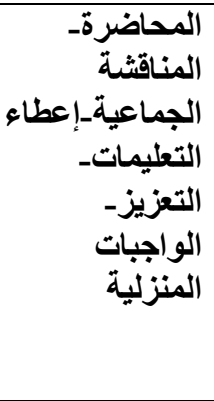 & 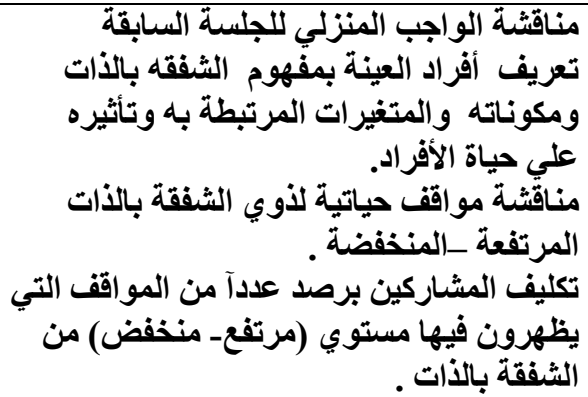 & الشفقة بالذات & \&-r \\
\hline • r ادقيقه & 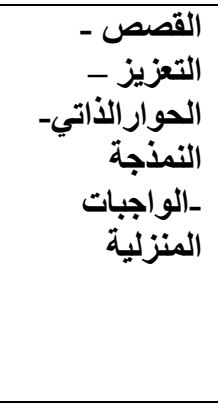 & 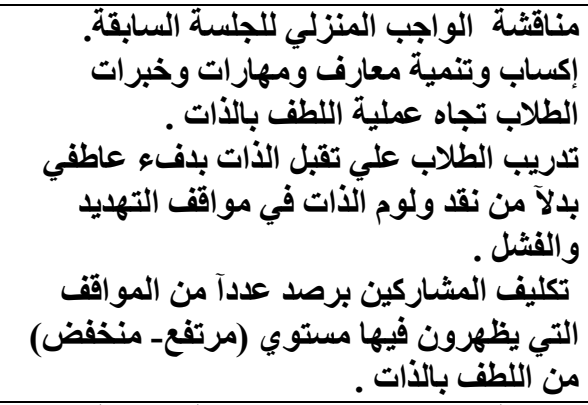 & اللطف بالذات & 7.0 \\
\hline • بدقيقة & المالمناضثة المزيزة & 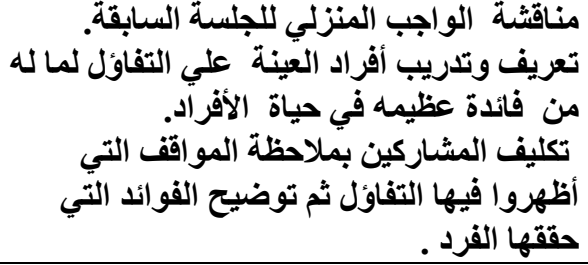 & مرغوبة التفائل كسمة & $\mathrm{v}$ \\
\hline
\end{tabular}




\begin{tabular}{|c|c|c|c|c|}
\hline • بدقيقة & 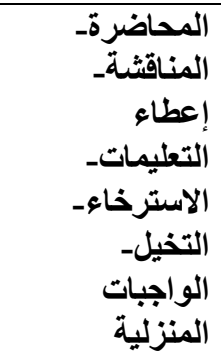 & 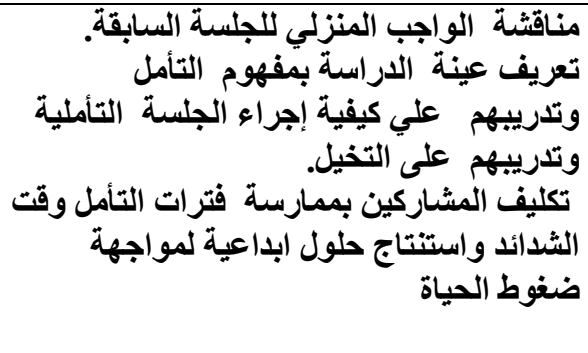 & التأمل & $\hat{~}$ \\
\hline • r ادقيقة & 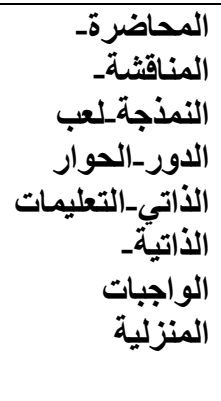 & 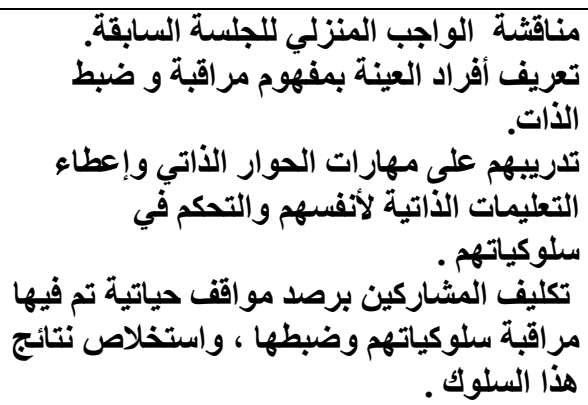 & ضربط الذاتة الذات ، & $1 \cdot-9$ \\
\hline . بدقيقة & 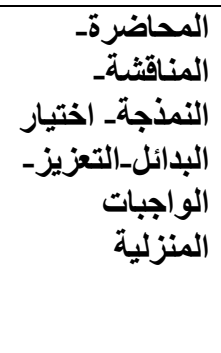 & 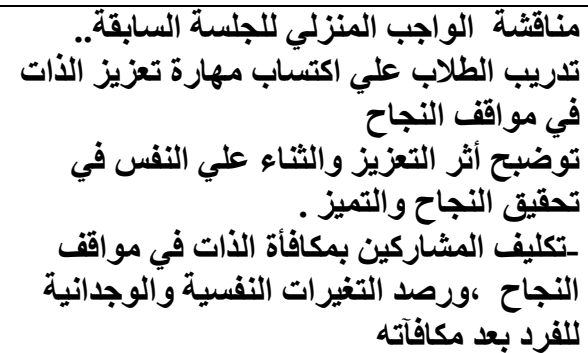 & تعزيز الذات & 11 \\
\hline دقبقة & 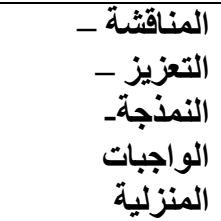 & 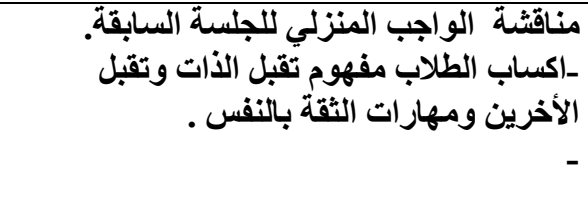 & الثقة بالذات & IT \\
\hline دقيقة & 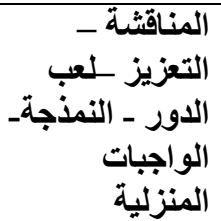 & 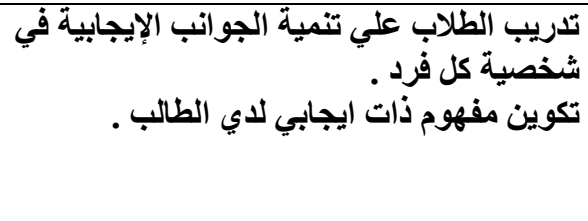 & ايجابي ذفوم ذات & $1 \pi$ \\
\hline دقيقة & 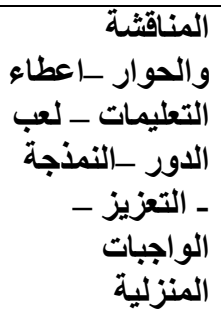 & 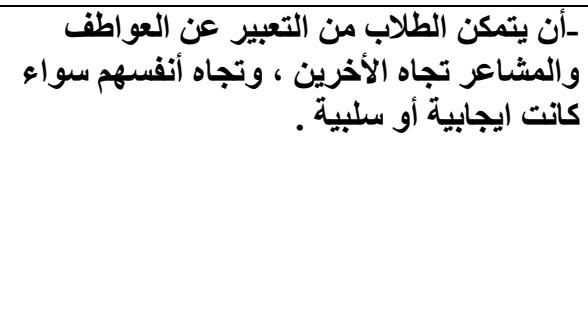 & الوالتعاطفة المثة & $10_{-1} \mid$ \\
\hline • r ادقيقة & 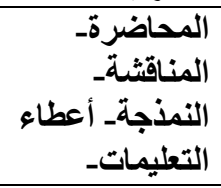 & 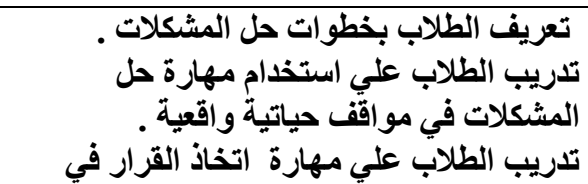 & حل المشكلات & $1 V_{-17}$ \\
\hline
\end{tabular}


177

\begin{tabular}{|c|c|c|c|c|}
\hline & 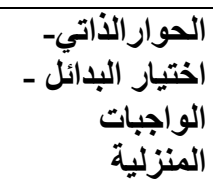 & المو اقف الطارئة & واتخاذ القرار & \\
\hline 1 ادقيقة & 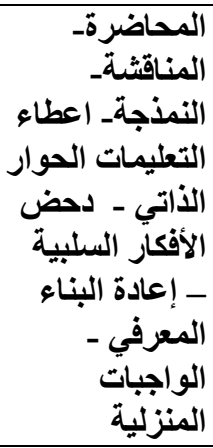 & 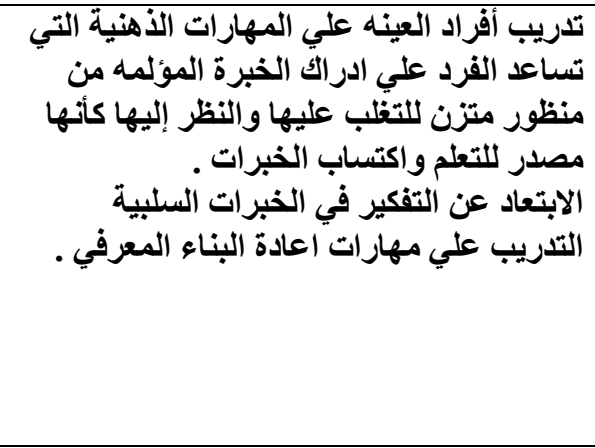 & اليقظة الذهنية & $r \cdot-11$ \\
\hline . آدقيقة & 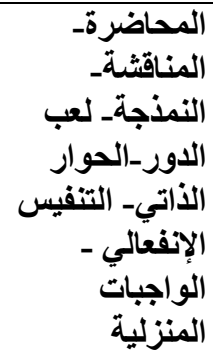 & 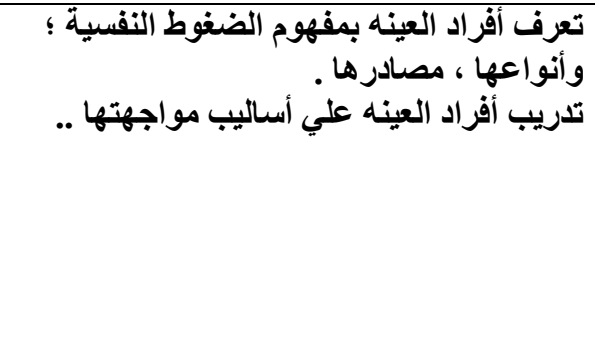 & الضفية & $r_{1}$ \\
\hline • r ادقيقة & 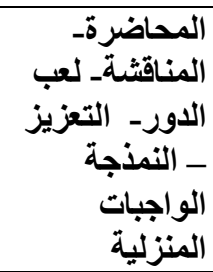 & 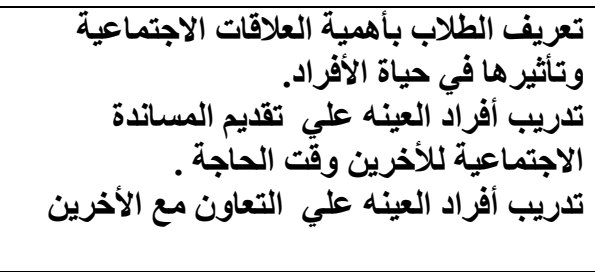 & الاجتماندية & Yr-YY \\
\hline ᄉ ادقيقة & 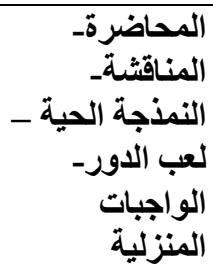 & 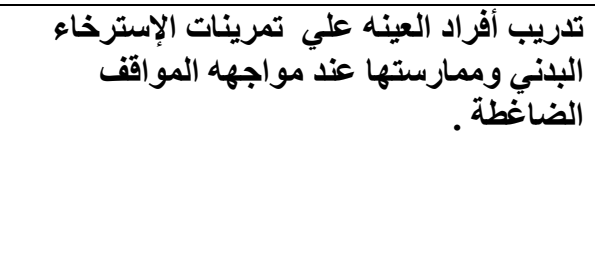 & الإسترخاء & YY-Y \\
\hline . זدقيقه & 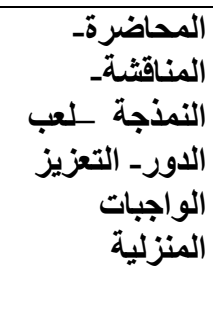 & 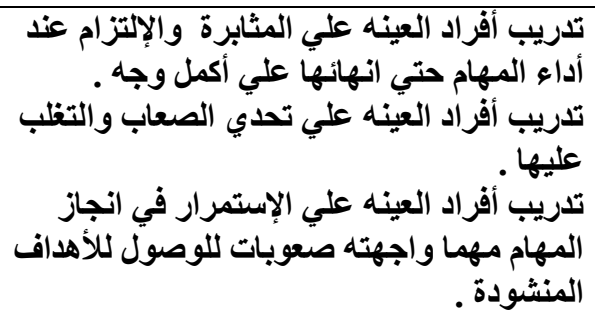 & المثابرة & rv \\
\hline . זدقيقه & 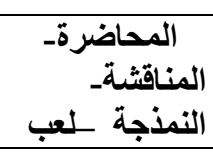 & 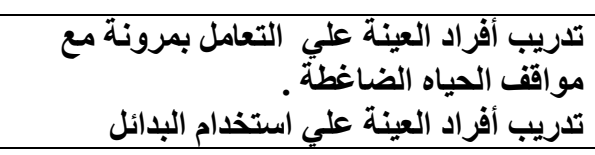 & المرونة & $r \wedge$ \\
\hline
\end{tabular}


178

\begin{tabular}{|c|c|c|c|c|}
\hline & الألواجبات التعزيز - المنزية & 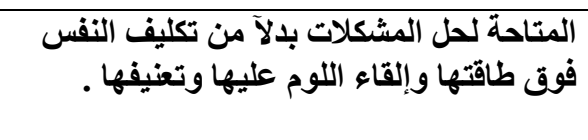 & & \\
\hline 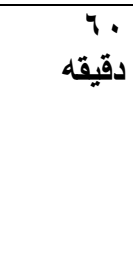 & 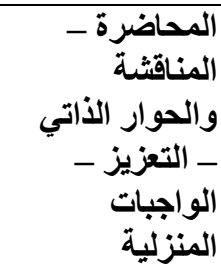 & 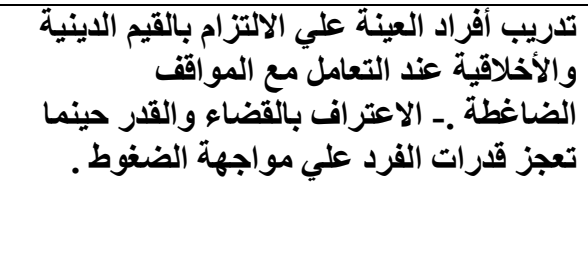 & القيم الاينية & $r q$ \\
\hline . זدقيقه & المناقئة & 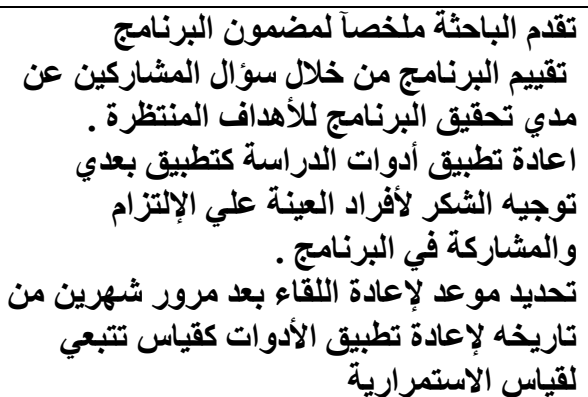 & الختامية & $r$. \\
\hline
\end{tabular}

خطوات الار اسةة :

للإجابة عن أسئلة الدر اسة والتحقق من فروضها اتبعت الباحثة الخطو ات التالية :

ا - الاطلاع علي التزاث السيكولوجي لمتغيرات الدراسة ، و أيضا الاطلاع علي

الدر اسات السابقة ذات الصلة و القيام بالدر اسة الناقدة لها لتوظيفها في صياغة

$$
\text { فروض الدر اسة و التحقق منها. }
$$

r- اعداد أدوات الدر اسة المناسبة لعينة الدر اسة و التحقق من كفاءتها السيكومترية. r- اختيار عينة الدر اسة من طلاب كلية التربية جامعة كفر الشيخ.( تضمن الأقسام

$$
\text { العلمية و الأدبية ). }
$$

ع- القيام بالتطبيق القبلي لمقياسي الصدود النفسي والثفقة بالذات علي المجموعتين

$$
\text { التجريبية و الضابطة. }
$$

- القيام بتطبيق البرنامج علي المجموعة التجريبية دون الضابطة .

7- رصد نتائج الدراسة و القيام بتحليلها باستخدام الأساليب الإحصائية المناسبة .

V- منافشة نتائج الدر اسة و التحقق من الفروض و استخر اج النتائج وتفسير ها.

^- وضع مجمو عة من التوصيات و المقترحات و الدر اسات المستقبلية في ضوء ما

$$
\text { توصلت إلية الدراسة من نتائج. }
$$


نتائج الفرض الأول ، وينص علي :" توجد علاقة ارتباطية موجبة دالة إحصائياً بين

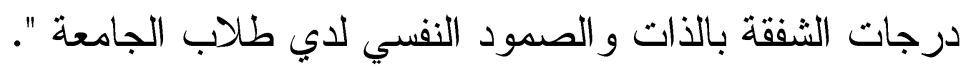

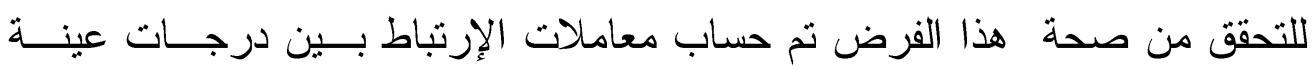
الدراسة (. - (1) طالب وطالبة من الفرق المختلفة و التخصصات العلمية و الأدبية علي

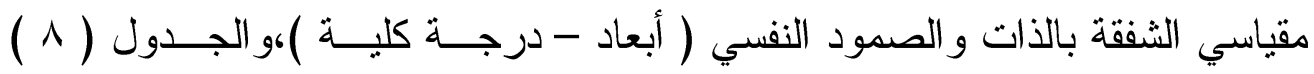

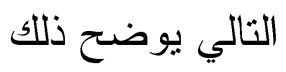

جدول (N) معاملات الارتباط بين كل من مقياس الثفقة بالذات و الصدود النفسي $(1$. (1)

\begin{tabular}{|c|c|c|c|c|c|c|}
\hline \multicolumn{6}{|c|}{ الصمود النفسي } & \multirow[b]{2}{*}{ الثفقة بالذات } \\
\hline الالكلية & والكفاءة الوجدانية & حل المشكلات & المرونة & المثابرة وتحقيق الأهداف & الألكاية & \\
\hline $\begin{array}{c}* . \wedge \varepsilon \\
*\end{array}$ & $* * \cdot . r \Lambda$ & $* * . . V V$ & $* * \cdot . V V$ & $* * \cdot . V r$ & $* * \cdot \vee \vee$ & اللطف بالذات \\
\hline $\begin{array}{c}* . r Y \\
*\end{array}$ & $* * .79$ &. .14 & $* * \cdot r$. & $* ., Y r$ & $* ., Y \leq$ & الإنسانية المشتركة \\
\hline $\begin{array}{c}* . \leqslant 0 \\
*\end{array}$ & $* * . .0 T$ & $* * \cdot r r$ & $* * . . \leqslant r$ & $* * ., r \varepsilon$ & $* * . \mu \wedge$ & اليقظة الذهنية \\
\hline$* \cdot{ }_{*}^{*}$ & $* * . .09$ & $* * .74$ & $* * . . V r$ & $* * .70$ & $* *, v$. & الارجة الكلية \\
\hline
\end{tabular}

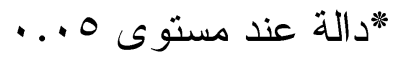

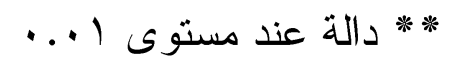
يتضح من الجدول ( ^) ما يلي :

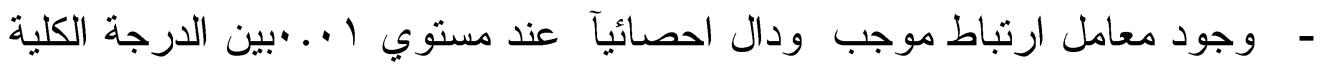

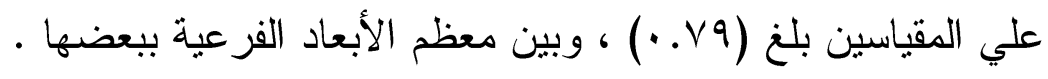

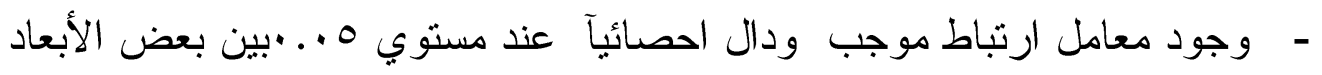
الفرعية (الإنسانية المشتركة- الكفاءة الذاتية ، الإنسانية المشتركة -لمثابرة

$$
\text { وتحقيق الأهداف ) . }
$$

وجود ارتباط بسيط لم يصل لمستوي الدلالة بين بعـــ الإنسـانية المشــتركة وحسل

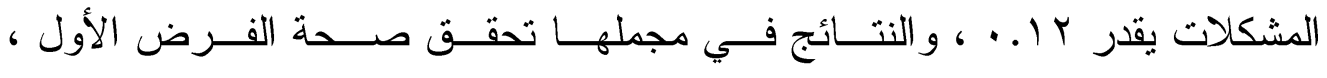
وتتفة 
الســــ Neff \& McGehee,2010 Kurilova,2013،

( Trompetter et al.,2017

- و انفردت دراسة واحدة من هذه الدراسات بتحديد القدرة التفسيرية للثفقة بالذات في الصمود النفسي( Kurilova,2013) فقد أثنارت ان الدرجة الكلية للشفقة بالذات تفسر ه \%من التباين في الصمود النفسي ، واللطف بالذات ، و عدم

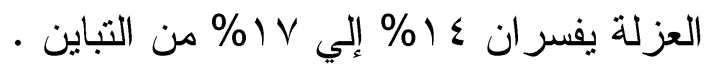

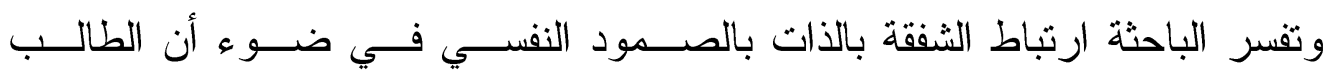

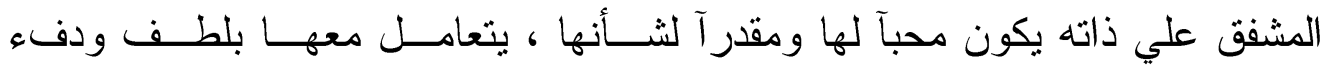

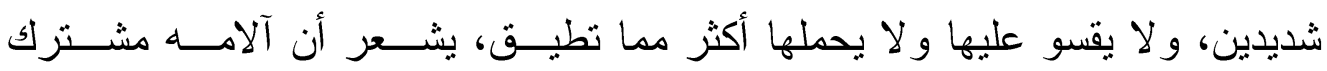

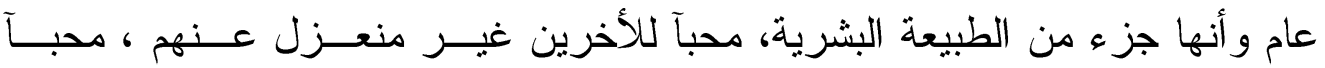

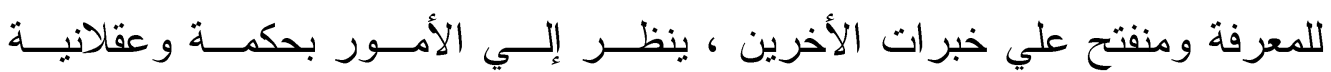

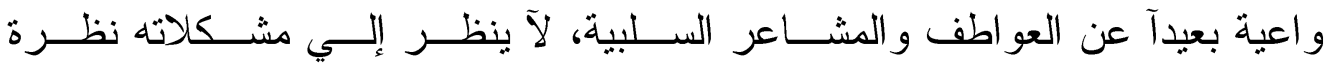

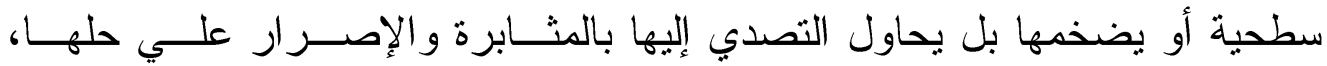

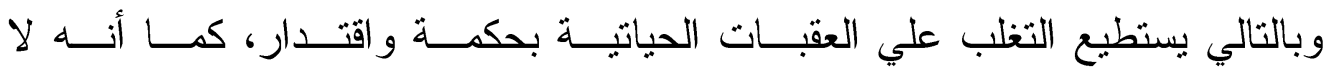

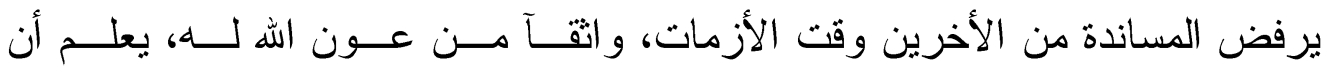

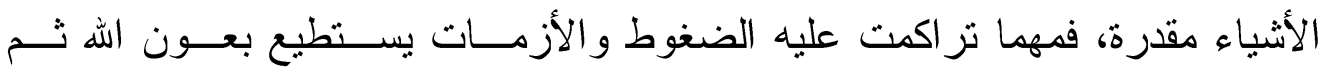

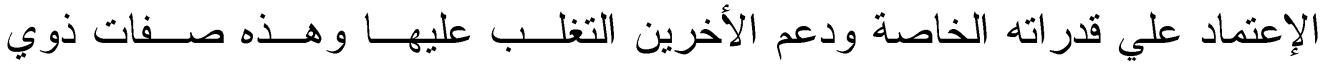

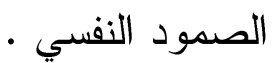
نتائج الفرض الثاني : ينص الفرض على إنه "توجد فروق ذات دلالة إحصائية بين

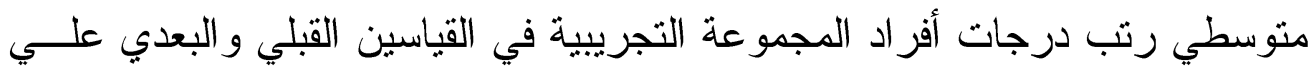
مقياسي الثفقة بالذات و الصمود النفسي لصالح القياس البعدي" .

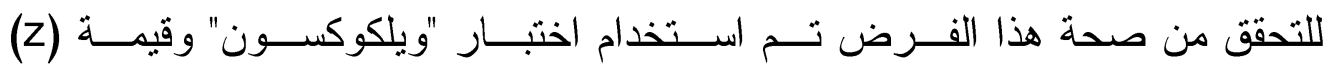
للكثف عن دلالة تلك الفروق ، و الجدول (9) يوضح ذللك. 
IV

جدول (9) الفروق بين متوسطات رتب درجات طلاب المجموعة التجريبية في القباسبن القبلي والبعدي علي مقياسي الثفقة بالذات و الصدود النفسي لبني

\begin{tabular}{|c|c|c|c|c|c|c|c|c|c|c|}
\hline \multirow{2}{*}{ مستؤي } & \multirow{2}{*}{ قيمة Z } & \multicolumn{2}{|c|}{ الرتب.الموجبة(+) } & \multicolumn{2}{|c|}{ الرتب السالبة(-) } & \multirow{2}{*}{ معياري } & \multirow[t]{2}{*}{ متوسط } & \multirow{2}{*}{ ن } & \multirow{2}{*}{ | القياس| - ل | } & \multirow{2}{*}{ الأبعاد } \\
\hline & & \multirow{3}{*}{00} & \multirow{3}{*}{0.0} & \multirow{3}{*}{$\because \cdot$} & \multirow{3}{*}{$\because \cdot$} & & & & & \\
\hline \multirow{2}{*}{$\because \cdot 1$} & \multirow{2}{*}{ Y.AI } & & & & & $1.1 \mathrm{~V}$ & 11.7. & 1. & قبلي & \multirow{2}{*}{ بالذات } \\
\hline & & & & & & r.rA & rı.q. & 1. & |بعدي | بع | & \\
\hline \multirow{2}{*}{$\because \cdot 1$} & \multirow{2}{*}{ r.A. } & \multirow{2}{*}{00} & \multirow{2}{*}{0.0} & \multirow{2}{*}{$\because \cdot$} & \multirow{2}{*}{$\because \cdot$} & 1.77 & 9.9. & 1. & قبلي & \multirow{2}{*}{ الالمثتركة } \\
\hline & & & & & & r.. & rr.r. & 1. & | بعدي | & \\
\hline \multirow{2}{*}{$\because \cdot 1$} & \multirow{2}{*}{ Y.AI } & \multirow{2}{*}{00} & \multirow{2}{*}{0.0} & \multirow{2}{*}{$\because \cdot$} & \multirow{2}{*}{$\because \cdot$} & $1 . \wedge \varepsilon$ & 1.0. & 1. & قبلي & \multirow{2}{*}{ الذهنية } \\
\hline & & & & & & T.rV & rr.t. & 1. & | بعدي | - ب | & \\
\hline \multirow[b]{2}{*}{$\because \cdot 1$} & \multirow[b]{2}{*}{ r.A. } & \multirow[b]{2}{*}{00} & & & & r.A. & $r r$ & 1. & قبلي & الدرجة \\
\hline & & & 0.0. & $\because$ & $\because$ & 0.11 & I.r.A. & 1. & | بعدي | - بع | & للالثفقة \\
\hline & & & & & & r.17 & 10.v. & 1. & |قبلي & الكفاعة \\
\hline$\because 1$ & $1 . \cdots$ & 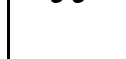 & $\because$ & $\because$ & $\because$ & r.०9 & $\varepsilon r .7$. & 1. & |بعدي | بع | & الأتية \\
\hline & & & & & & 1.79 & $1 \varepsilon$ & 1. & قبلي & المثابرة \\
\hline$\because 1$ & r.Ar & 00 & 0.0. & $\because \cdot$ & $\because \cdot$ & r.r. & $\varepsilon 1.7$. & 1. & | بعدي | - بع | & والأهداف \\
\hline$\ldots 1$ & r 11 & 00 & 0.0 . & $\cdots$ & $\cdots$ & $1.9 \varepsilon$ & 10.v. & 1. & قبلي & \\
\hline & & & & $\cdot$ & $\because$ & $\{.01$ & $\varepsilon Y . \Lambda$. & 1. & بعدي & المعروسة \\
\hline 1,1 & r $\Delta_{1}$ & 00 & 00. & $\therefore$ & . & $1 . v r$ & $1 \leq .1$. & 1. & قبلي & حل ل \\
\hline$\because 1$ & 1.01 & 0 & 0.0 & $\because$ & $\because$ & r.YI & 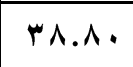 & 1. & بعدي & المشكلات \\
\hline & & & & & & r.YY & IE.r. & 1. & قبلي & الكفاعة \\
\hline$\because+1$ & r.A. & 00 & 0.0. & $\because \cdot$ & $\because \cdot$ & $\varepsilon .11$ & $\varepsilon r . v$. & 1. & | بعدي | & والاجتماعية \\
\hline & & & & & & $0 . .9$ & Vr.A. & 1. & قبلي & الدرجة \\
\hline$\because \cdot 1$ & Y.AI & 00 & 0.0 & $\because$ & $\because$ & 1.70 & $r .9 .0$. & 1. & | بعدي | - ل | & للنفمود \\
\hline
\end{tabular}


يتضح من نتائج جدول (9) وجود فـروق دالــة احصـــائياً عنــــ مســتوي ا +.، بين متوسطات رتب درجات أفراد المجموعــة التجريبيـة فـي القباســين القبلــي و البعدي علي مقياسي الشفقة بالذات ، الصمود النفسـي لصــالح القيــاس البعـدي

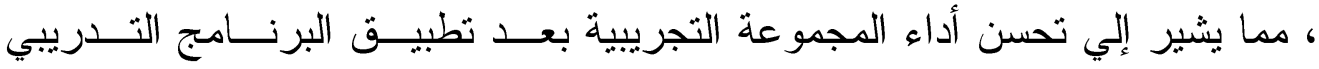
عليها ـ و هذه النتائج في مجملها تحقق صحة الفرض الثاني •

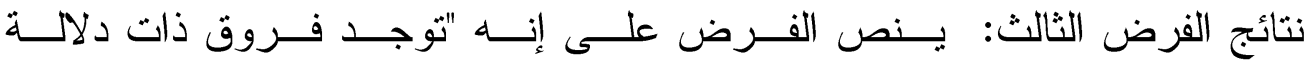
إحصائية بين متوسطي رتب درجات أفــر اد المجمــوعتين التجريبيــة و الضـــابطة

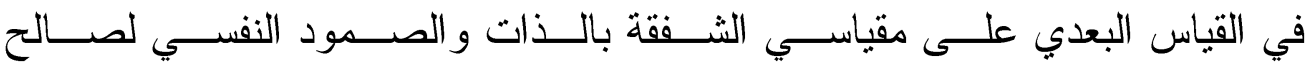
المجمو عة التجريبية".

للتحقق من صحة هذا الفـرض تــم اســتخدام اختبار"مـــان ويتـــي" وقيمــة (U) للكثف عن دلالة تلك الفروق بين المجمو عتين،و الجدول ( • () يوضح ذلك. جدول (. 1) الفروق بين متوسطات رتب درجات طلاب المجدوعتبن التجريبية والضابطة في القياس البعدي لمقياسي الثفقة بالذات و الصسود النفسي (أبعاد - درجة كلية)

\begin{tabular}{|c|c|c|c|c|c|c|c|c|c|}
\hline مستوي & قيمة Z & مان ويتنى & مجموع الرتب & متوسط & أحعياري & متوسط & ن & لمجموعات & الأبعاد \\
\hline \multirow{2}{*}{$\cdot, \cdot 1$} & \multirow{2}{*}{ r.Vq } & \multirow{2}{*}{$\because \cdot$} & 100 & 10.0. & r.YA & rı.q. & 1. & التجريبية & \multirow{2}{*}{ اللطف بالذات } \\
\hline & & & 00 & 0.0. & $1 . r 1$ & Ir.A. & 1. & الضابطة & \\
\hline \multirow{2}{*}{$\cdot, \cdot 1$} & \multirow{2}{*}{ r.Vq } & \multirow{2}{*}{$\because \bullet$} & 100 & 10.0. & r... & rr.r. & 1. & التجريبية & \multirow{2}{*}{ الانسانية } \\
\hline & & & 00 & 0.0. & 1.10 & $1 . .9$ & 1. & الضابطة & \\
\hline \multirow{2}{*}{$\cdot, .1$} & \multirow{2}{*}{ r.v 9} & \multirow{2}{*}{$\because \bullet$} & 100 & 10.0. & r.rv & rr.t. & 1. & التجريبية & \multirow{2}{*}{ اليقظة الذهنية } \\
\hline & & & 00 & 0.0. & Y.r. & 11 & 1. & الضابطة & \\
\hline \multirow{2}{*}{$\cdot, .1$} & \multirow{2}{*}{ r.V 9} & \multirow{2}{*}{$\because \bullet$} & 100 & 10.0. & 0.11 & 1.r.A. & 1. & التجريبية & \multirow{2}{*}{ اللثفقة بالذات الكلية } \\
\hline & & & 00 & 0.0. & $r . v v$ & $r \varepsilon . v$. & 1. & الضابطة & \\
\hline \multirow{2}{*}{$\cdot, .1$} & \multirow{2}{*}{ r.^. } & \multirow{2}{*}{$\because \bullet$} & 100 & 10.0. & r.०q & $\varepsilon r . \neg$. & 1. & التجريبية & \multirow{2}{*}{ الكفاءة الأتية } \\
\hline & & & 00 & 0.0. & r.r. & $1 \leq . \wedge$. & 1. & الضابطة & \\
\hline \multirow[b]{2}{*}{$\cdot,+1$} & \multirow[b]{2}{*}{ r.vq } & \multirow[b]{2}{*}{$\cdots$} & 100 & 10.0. & r.r. & $\leqslant 1.7$. & 1. & التجريبية & \multirow{2}{*}{ الألهدافت } \\
\hline & & & 00 & 0.0. & 1.87 & $1 \leqslant . v$. & 1. & الضابطة & \\
\hline
\end{tabular}




\begin{tabular}{|c|c|c|c|c|c|c|c|c|c|}
\hline مستوى الدلائة & قيمة Z & مان ويتنى & مجموع الرتب & متوسط الرتب & انحراف & متوسط & $\dot{ن}$ & المجموعات & الأبعاد \\
\hline \multirow{2}{*}{$\cdot, \cdot 1$} & \multirow{2}{*}{ r.^. } & \multirow{2}{*}{$\cdots$} & 100 & 10.0 & $\varepsilon .01$ & $\varepsilon Y . \wedge$. & 1. & التجريبية & \multirow{2}{*}{ المرونة } \\
\hline & & & 00 & 0.0. & 1.19 & $1 \varepsilon .1$ & $1 \cdot$ & الضابطة & \\
\hline \multirow{2}{*}{$\cdot, \cdot 1$} & \multirow{2}{*}{ r.vq } & \multirow{2}{*}{$\cdots$} & 100 & 10.0 & r.7I & r^.^. & 1. & التجرييية & \multirow{2}{*}{ حل المشكلات } \\
\hline & & & 00 & 0.0. & $1.7 \varepsilon$ & $1 \leq .0$ & 1. & الضابطة & \\
\hline \multirow[b]{2}{*}{$\cdot, \cdot 1$} & \multirow[b]{2}{*}{ P.Vq } & \multirow[b]{2}{*}{$\cdots$} & 100 & 10.0. & $\varepsilon .11$ & $\varepsilon r . V$. & $1 \cdot$ & التجريبية & \multirow{2}{*}{ والاكفاءة الاجنماعية } \\
\hline & & & 00 & 0.0. & 1.07 & I\&.V. & $1 \cdot$ & الضابطة & \\
\hline \multirow{2}{*}{$\cdot, \cdot 1$} & \multirow{2}{*}{ r.v^ } & \multirow{2}{*}{$\because \cdot$} & 100 & 10.0 & 1.70 & r.9.0. & $1 \cdot$ & التجريبية & \multirow{2}{*}{ للصدودة الكلية } \\
\hline & & & 00 & 0.0. & $\varepsilon . V$. & Vr.A. & 1. & الضابطة & \\
\hline
\end{tabular}

يتضح من الجدول ( • (1) وجود فروق دالة إحصــائياً عنــد مســتوى (1 +. •) بــين متوسطات رتب درجات طلاب المجموعتين التجريبيــة والضـــابطة بعــــ تطبيــق البرنامج على جميع أبعاد مقياسي الثــقة بالــذات و الصــمود النفسـي و الدرجــة الكلية لكل مقياس لصالح المجموعــة التجريبيــة ، مدــا يعنــي تحســن درجــات طلاب المجموعة التجريبية بعد تعرضهم لجلسـات البرنــامج، وبــذلك يــتم قبــول

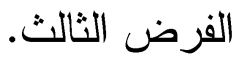
الفرض الر ابع : ينص الفرض على إنه "لا توجــــــــروق ذات دلالـــة إحصـــائية بين منوسطي رتب درجات أفر اد المجموعــة التجريبيــة فـي القياسـين البعـدي و التتبحي علي مقياسي الشفقة بالذات و الصمود النفسي(أبعاد- درجة كلية )". للتحقق من صحة هذا الفرض تم اســتخدام اختبــار "ويلكوكســون" وقيمــة (z) للكثف عن دلالة تلك الفروق ،و الجدول (1) يوضح ذلك. 
جدول (11) الفروق بين متوسطات رتب درجات طلاب المجموعة التجريبية في القياسين البعدي و التتبعي علي مقياسي الثفقة بالذات و الصدود النفسي

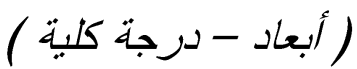

\begin{tabular}{|c|c|c|c|c|c|c|c|c|c|c|}
\hline مستوي & قيمة & يجة)(+) & الرتب.المو & سالبة)(-) & الرتب الد & انحراف & متو سط | & $\dot{ن}$ & لقبـاس & الأبعاد \\
\hline & & المجموع| & المتوسط | & |المجموع| & لمتوسط| & & & & & \\
\hline & & & & & & r.YA & rs.q. & 1. & بعدي | بعا| & \\
\hline غيلر & 18 & 10 & 1 & 10 & $\theta$ & r... & rq.1. & 1. & تتبعي | & كالدات \\
\hline & 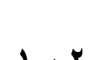 & 14 & 0 & wy & पy & r... & rr.r. & 1. & بعدي & الانساتية \\
\hline تيز & & &. & & r & r.q1 & r 1.0. & 1. & تتبعي & المشتركة \\
\hline & & & & & & r.rV & rr.t. & 1. & بعدي & \\
\hline عيلز داله & 1.9 & IV & 2.10 & $1 \mathrm{~T}$ &.$T$ & 1.70 & ri.A. & 1. & تتبعي & 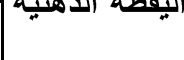 \\
\hline & L & 14 & $0, y$ & w & $6 \mathrm{Va}$ & 0.11 & $1 . r . \Lambda$. & 1. & بعدي & الدرجة الكلية \\
\hline 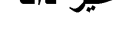 & & & & & & $r .91$ & 1.r.s. & 1. & تتبعي & للشفقة بالذات | \\
\hline & & & & & & r.०Q & $\varepsilon r . q$. & 1. & بعدي & \\
\hline حيز & 1.1. & 11 & T & 21 & r.tr & r.99 & $\leqslant$ r.o. & 1. & تتبعي & \\
\hline & & & & & & r.r. & $\varepsilon 1.7$ & 1. & بعدي | & المثابرة \\
\hline غير دالة &.$V \mu$ & $r \cdot .0$. & $0.1 \pi$ & $\leqslant \mu .0$. & $0 . V_{0}$ & Y.V $\varepsilon$ & \&1 & 1. & تتبعي | & وتحقيق \\
\hline & & & & & & & & & & \\
\hline it & 1 & 14 & r. & $\mu$ & 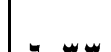 & $\{.01$ & $\varepsilon r . \Lambda$. & 1. & بعدي & \\
\hline حير & 1.7 & or & 8.10 & 10 & . & $\varepsilon .9 \%$ & $\leqslant 1.9$. & 1. & تتبعي & إ) \\
\hline & & & & & & r.TI & 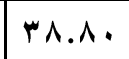 & 1. & بعدي | & \\
\hline تير & $\because v 1$ & 18.00 & 8.71 & 11.00 & (.n) & r... & ra.A. & 1. & تتبعي & حס ואט \\
\hline & & & & & & $\{.11$ & $\varepsilon r . v$. & 1. & بعدي & الكفاعة \\
\hline غير دالة &. .89 & rr & 0.0. & rr & 0.0. & $\ldots$ & & & & الوجدانية \\
\hline & & & & & & $r . . . \wedge$ & हT.T. & 1. & لبندي | & والاجتماعية \\
\hline & & & & & & 1.70 & r.9.0. & 1. & بعدي & ا الارجة \\
\hline غير دالة &. .74 & ri & $0.7 \mathrm{~V}$ & $r \varepsilon$ & $0.7 \mathrm{~V}$ & $V . V Y$ & r.^.\&. & 1. & تتبعي | & الكلية للصمود \\
\hline
\end{tabular}

يتضـح من نتائج جدول (1) عدم وجود فروق دالــة احصـــائياً بــين منوســـات رتب درجات أفر اد المجموعة التجريبية فـي القياسـين البعـدي والتبتهـي علـي

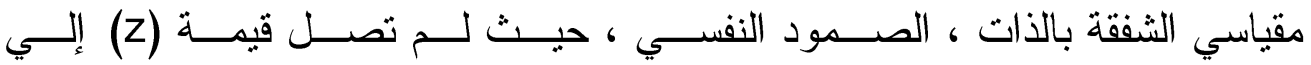




\section{IV $\varepsilon$}

مستوي الدلالة الإحصائية ، وهذه النتائج فـي مجملهــا تحقـق صـــة الفـرض

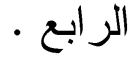

تفسير التتائج الخاصة بفعالية البرنامج : في تحســين مســتوي الثــفقة بالــذات و الصمود النفسي:

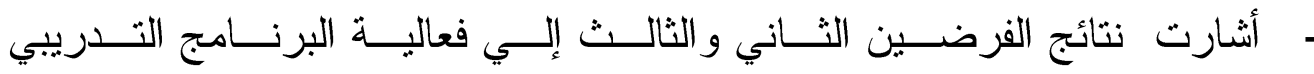
المستخدم في تحسين مستوي الثفقة بالــذات و الصـــمود النفسـي لــدي عينــة

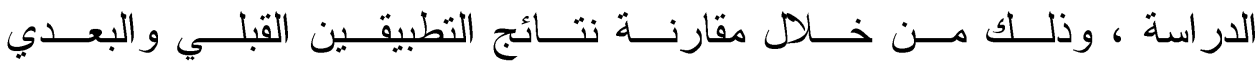
للمقياسين علي المجموعــة التجريبيــة ، وكانـــت الفــروق لصـــالح التطبيــق

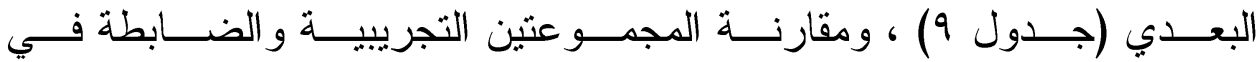
التطبيق البعدي للمقياسين ، وكانـــ الفـروق لصــالح المجموعـــة التجريبيـــة (جدول · (1) و هذه النتائج في مجملهــا تتفــق مـــع نتــائج الدر اســات الســابقة التي أثـارت إلي أنه من خلال البرامج الإرشــادية و التدريبيــة القائمــة علـي

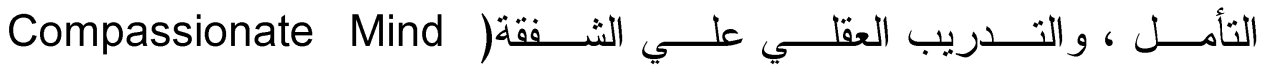

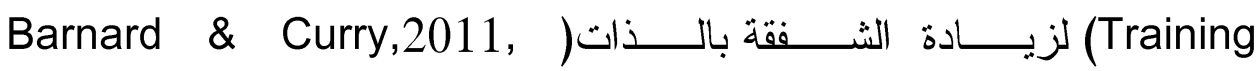
, Tobias Kriege ,et al,2016 ‘Amyfinlay, et al,2016 Karakasidou,A.,\&Stalikas,A. 2017, Karen\&Torty,2017 .( Mantelou ,A. et al,2017, وتزي الباحثة أن فنية المحاضــرة ســاهمت فــي اكســاب الطــلاب المعلومــات المهمه بطريقة منظمة ومتدرجة ، ولعبـــت فنيــة الحـــوار و المناقثـــة الجماعيــة

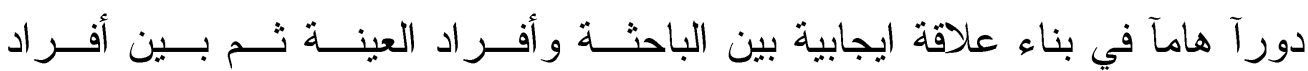
العينه وبعضهم ، و استشعر الطلاب من خلالهـــا أهميــة البرنــامج فــي التـدريب

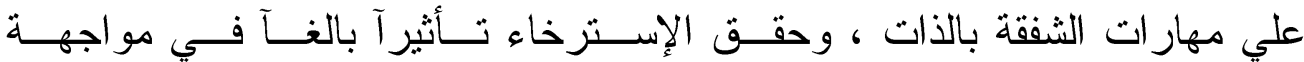
المواقف الحياتية الصعبة بهــدوء واتـز ان انفعـالي ، و أكــدت فنــــة الإســـرخاء

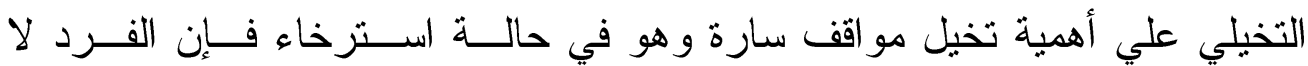

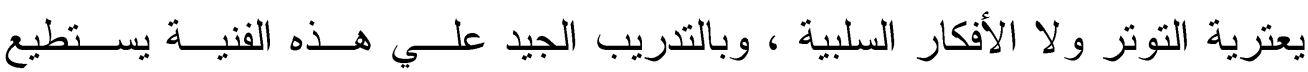
الطالب الإستمتاع بكل ما هو بديع ورائع وتتغير نظرثه السلبية للمو اقف . 
وقد أفاد الطالب من خلال تدريبه علي صرف انتباهــهـ عـن الأفكـــار المشــوهه

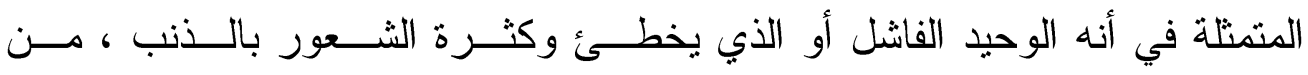

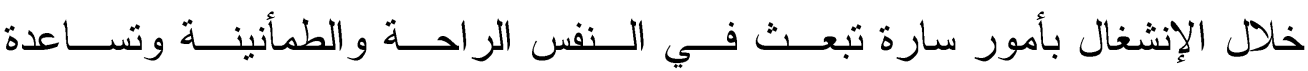

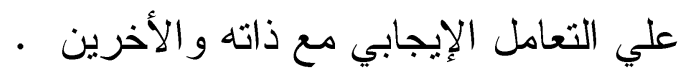

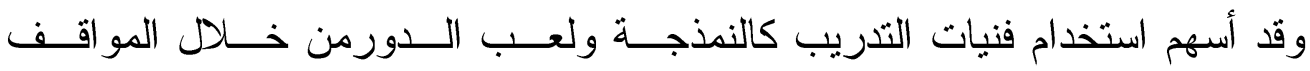

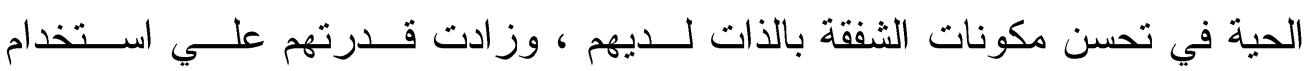

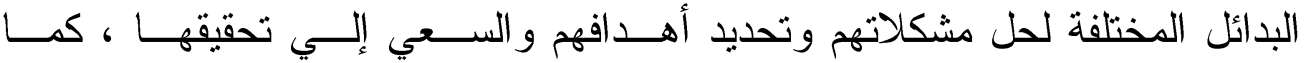

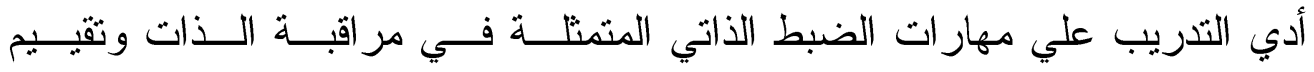

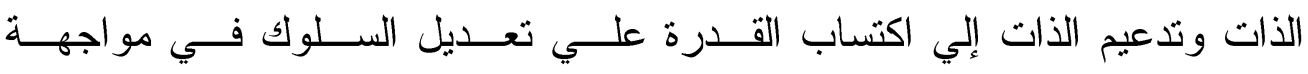

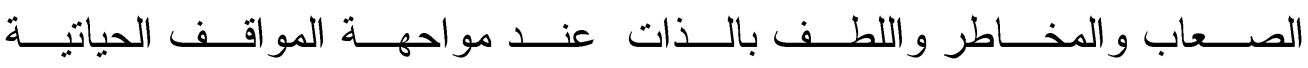

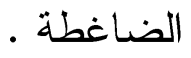

\section{وبالنسبة لاستمرارية فعالية البرنامج :}

فقد كثفت نتائج الفرض الرابع (جدول (1) عن عدم وجـود فــروق دالـــة بــين

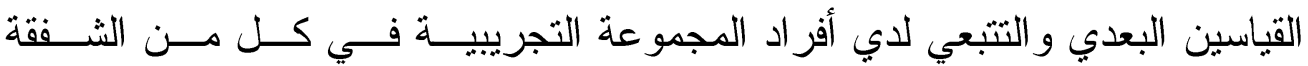

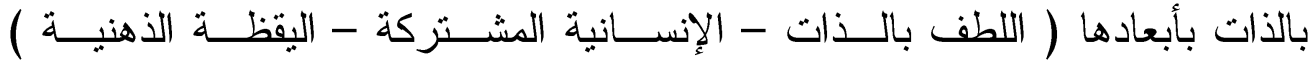

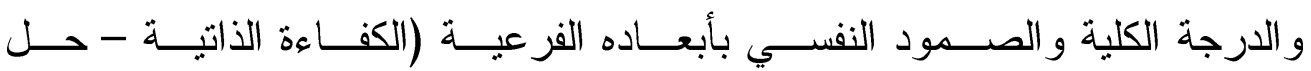

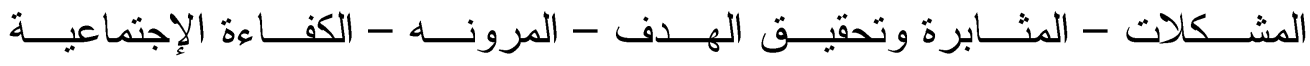

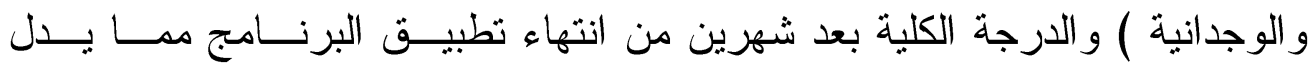
علي امتداد فعالية البرنامج واستمر اريته .

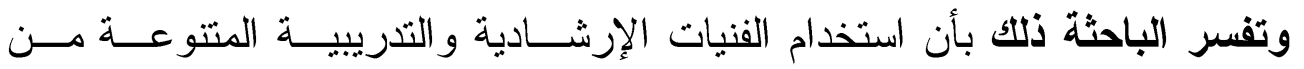

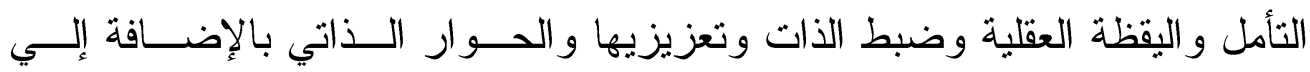

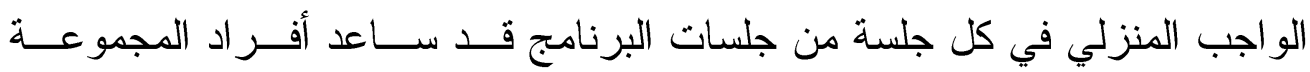

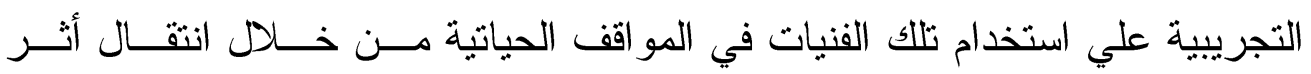

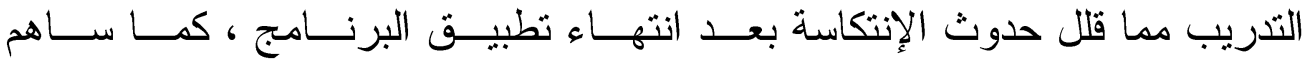

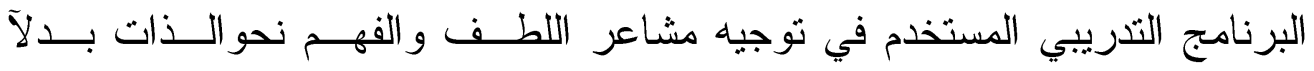

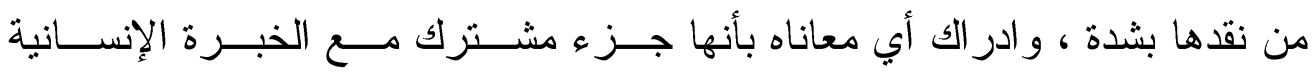




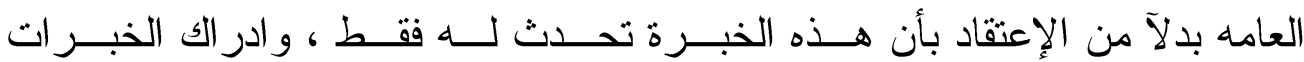
المؤلمه بعقلية متزنه بدلآ من الإفراط فـي الثــعور بــالألم ، وتعزيــز الكفــاءة

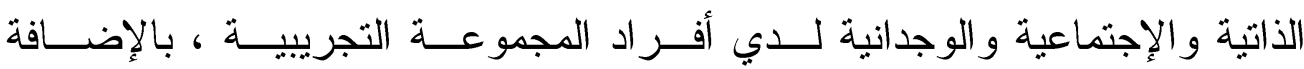

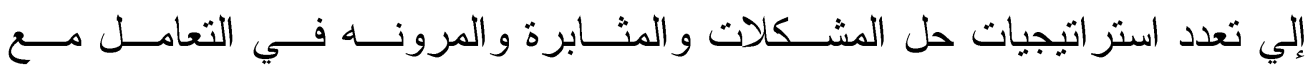

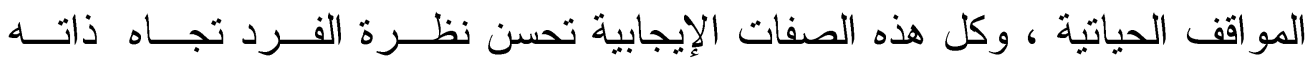
و الأخرين ، وبالتالي تجعل الفرد أكثر نجاحــآ وأكتــر ســـادة ورفاهيــة نفســية

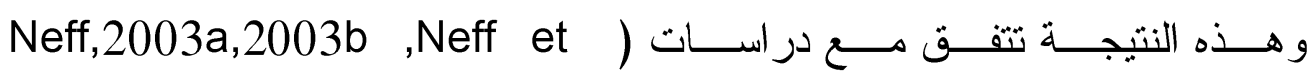
.(al,2007, Neely et al,2009 التوصيات والمقترحات : ا ـ تعزيز مكونات الثفقة بالذات لدي الأبناء و استمر ارية ممارستها في التعامل معهم

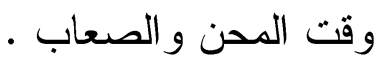

r. مساعدة الثباب علي تقييم جوانب القوة والضعف في شخصياتهم ، وتعزيز جوانب القوة و اللطف بالذات عند التعامل مع الجوانب السلبية r. دراسة البروفيل النفسي للأفر اد ذوي الثفقة بالذات . ع. استخدام الثفقة بالذات كمدخل علاجي لخفض الكمالية العصابية لدي الطلاب

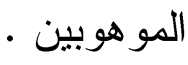
هـ استخدام الشفقة بالذات كمخل علاجي لخفض القلق أو الإكتئاب أو الوحدة النفسية لدي طلاب الجامعة . 7. استخدام الثفقة بالذات كمدخل لتنمية الأمل والتفاؤل أو التسامح أوالرفاهية النفسية أو اليقظة العقلية أو المرونه النفسية أوالحكمة لدي العاديين - غير العاديين و أسر هم .

V. استخدام الثفقة بالذات كمدخل علاجي لخفض مستوي العصابية لدي طلاب

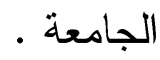
^. اجر اء المزيد من الدراسات لتحسين الثفقة بالذات لدي عينات متتوعة (الأكثر 


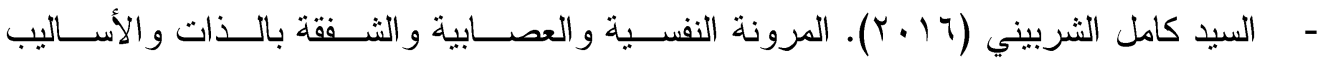

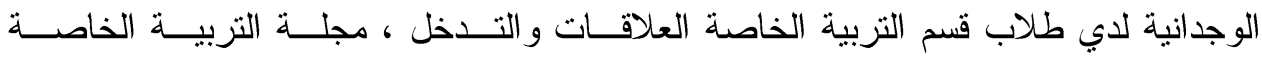

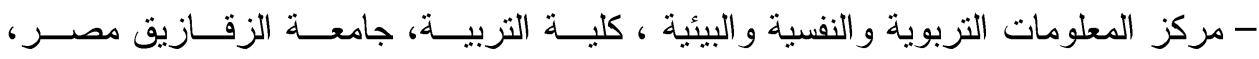

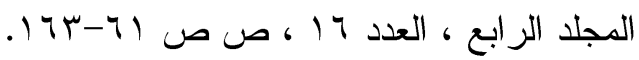

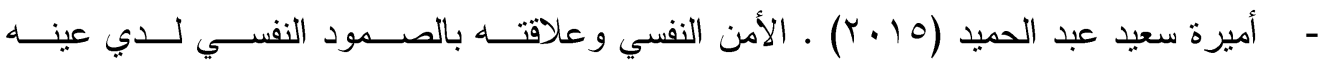

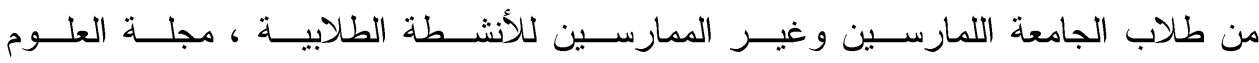

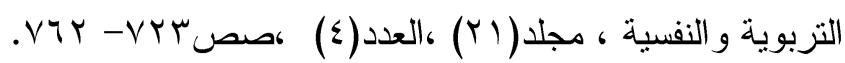

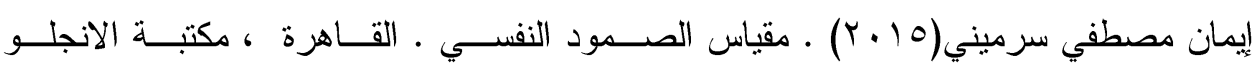
المصرية

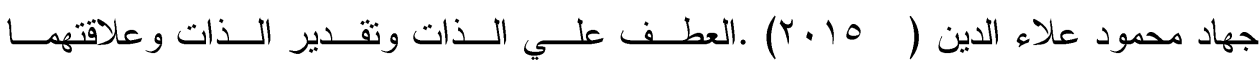

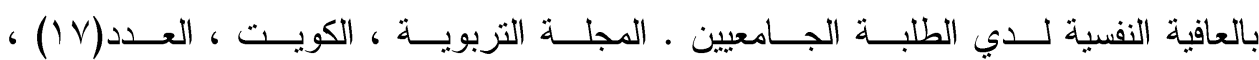

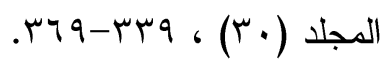

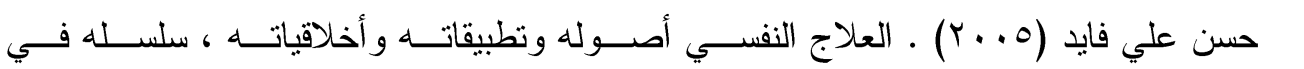

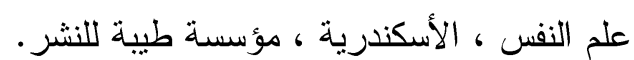

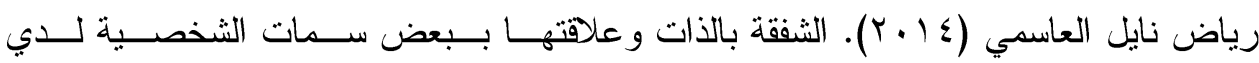

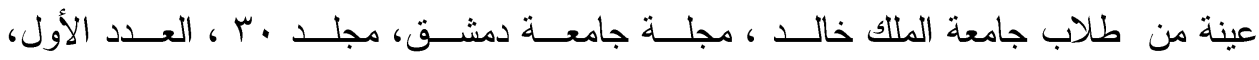
صصل1V-07.

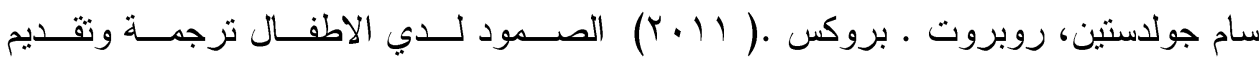
صفاء الاعسر ـ القاهرة : المركز القومي للترجمة.

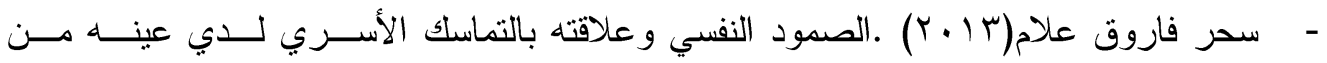

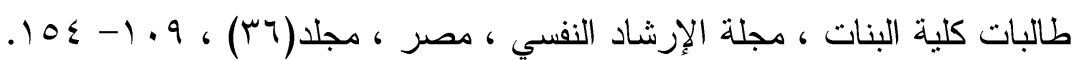

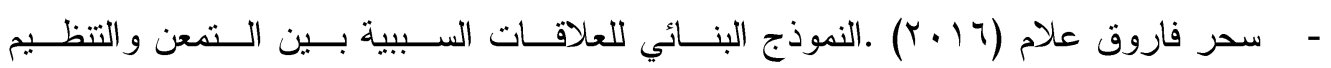

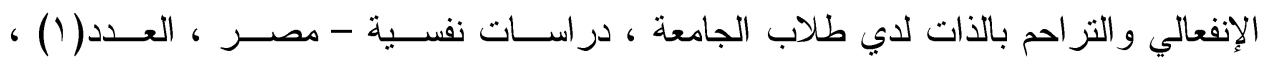

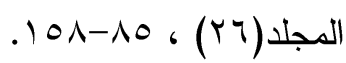

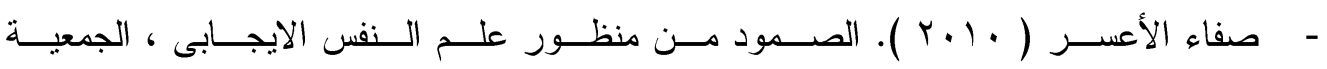

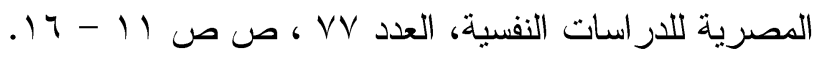

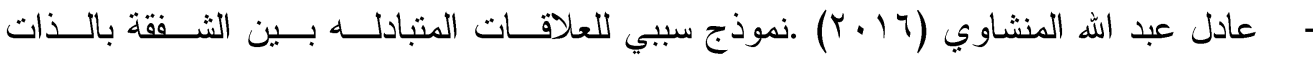

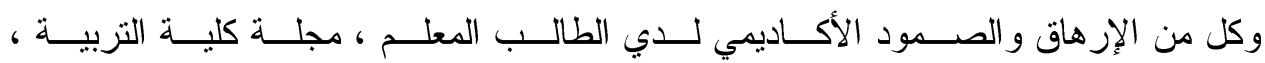

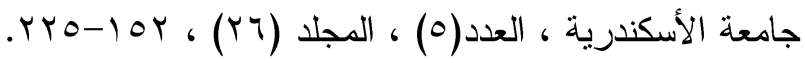




\section{IVA}

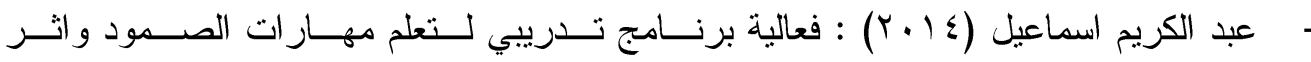

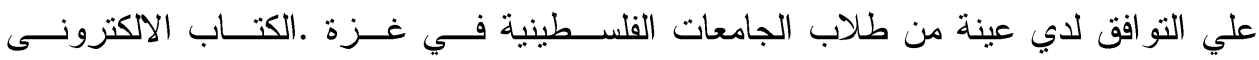

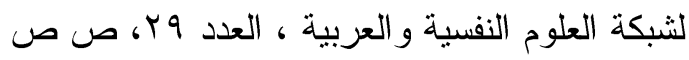

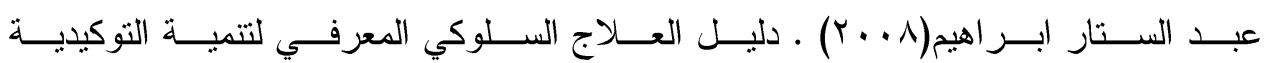

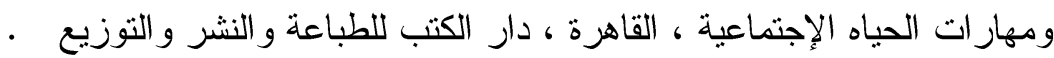

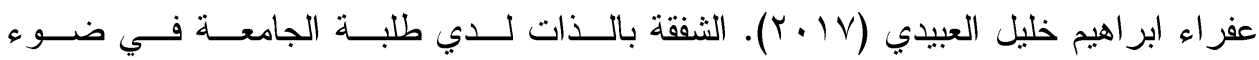

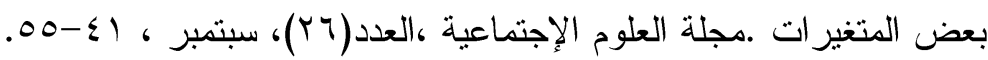

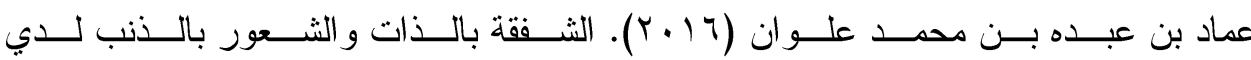

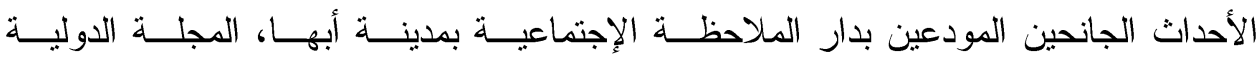

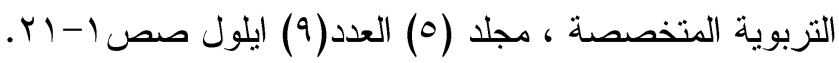

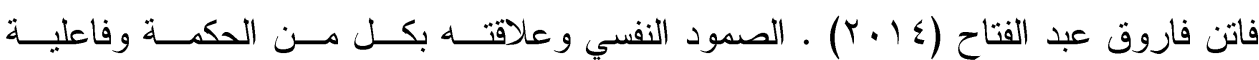

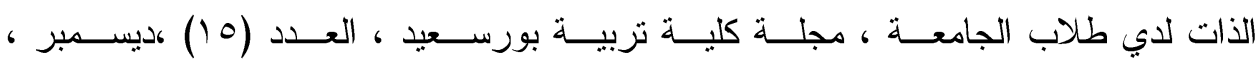
صص. .9-צ ז1.

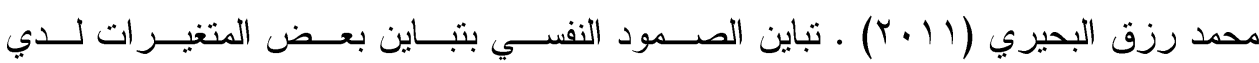

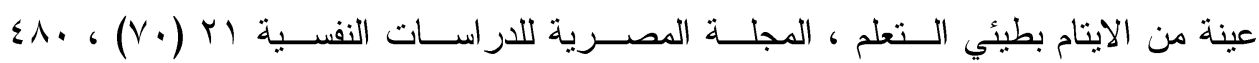
oro -

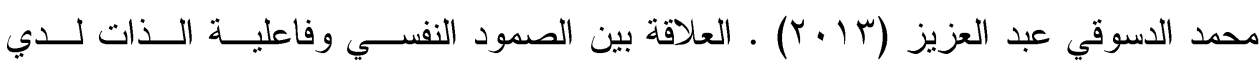

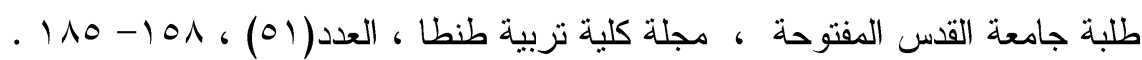

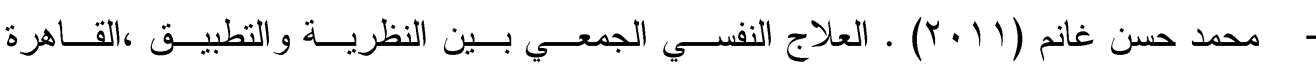
، الهيئة المصرية العامه للكنب.

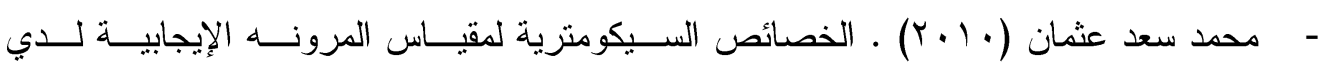

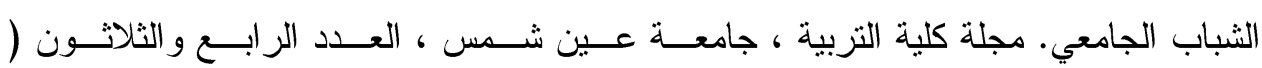

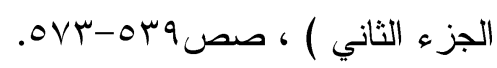

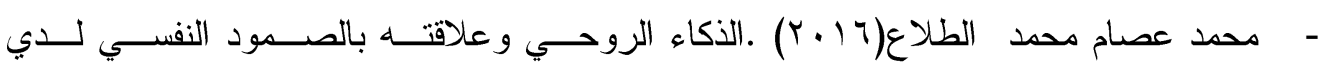

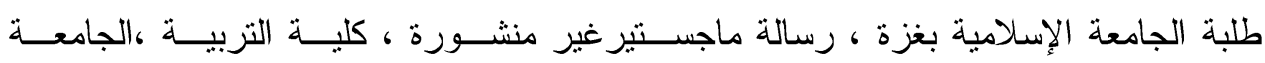
الاسلامية بغزة.

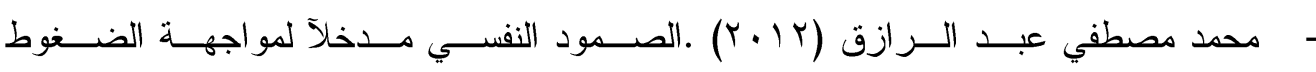

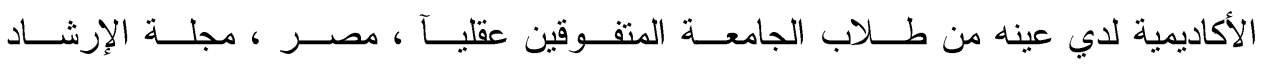

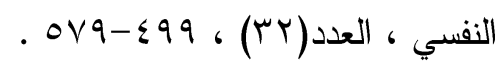




\section{$1 \vee 9$}

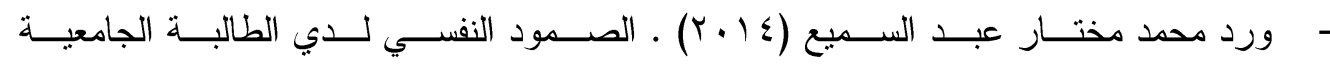

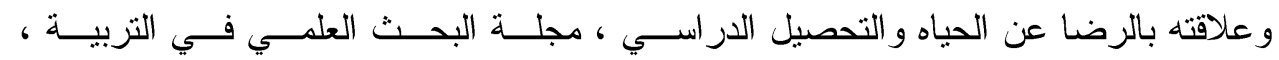

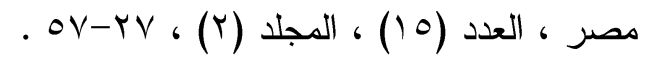

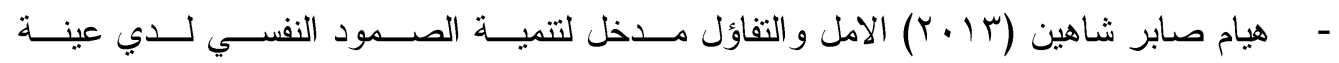

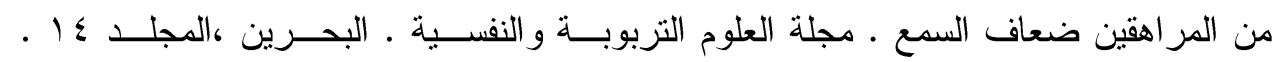

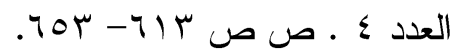

المراجع الاجنبية

- Archontia Mantelou ,E IRINI karakasidou (2017). The effectiveness of Brief Self-compassion intervention program on Self-compassion, positive and negative affect and life satisfaction .scientific research publishing. 8, 590-610.

- Akin, A., \& Kayis, A.(2011). Self-compassion And social support. International Conference on New Trends in Education and Their Implications 27-29 April, Antalya-Turkey.

- Allan,John F.\&Mckenna,Jim\&Dominey,Susan(2014) .Degrees of Resilience: Profiling Psychological Resilience and Prospective Academic Achievement in University Inductees British Journal of Guidance\&Counselling,V(42),n1,9-25..

- Allen,N.\&Knight,W.(2005).Mindfulness,compassion for self,and compassion for others. Implications for understanding the psychopathology and treatment of depression.In P. Gilbert(ED.),Compassion : Conceptualizations,research and use in psychotherapy . London: Rutledge,239-262.

- Amy finlay - Jones ,Robert Kane , and Clear Rees (2017). Selfcompassion on line : A pilot study of an internet -based Selfcompassion culdvation program for psychology trainees .journal of clinical psychologe Vol.73(7)797-816.

- Aydogdu,Bilge Nuran\&Celik,Hilal\&Eksi,Halil(2017).The Predictive Role of interpersonal sensitivity and Emotional SelfEfficacy on psychological Resilience among You Adults Eurasian Journal of Educational Research,n(69),37-54.

- Bayir,A.(2016).Difficulties Generating Self-Compassion:An Interpretative Phenomenological Analysis. The Journal of Happiness and Well-Being,4,1,15-33.

- Brach, T.(2003). Radical acceptance: embracing your life with the . 235 :heart of a Buddha. New York: Banta

- Barnard,L.K.\&Curry,J.F.(2011).Self,Compassion:Conceptualizatio ns, Correlates, \& Interventions. Review of General Psychology ,15,289-303. 


\section{$1 \wedge$.}

- Bayir,A.(2016).Difficulties Generating Self-Compassion:An Interpretative Phenomenological Analysis. The Journal of Happiness and Well-Being,4,1,15-33

- Bluth K.\& Eisenlohr-Moul T.(2017).Response to a mindful selfcompassion intervention in teens:A Within-Person association of mindfulness,self-compassion,and emotional Well-being outcomes.Journal of Adolescence,57,108-118.

- Breines,J.\&Chen,(2012).Self-Compassion Increases SelfImprovement Motivation. Personality and Social Psychology Bulletin,38(9),1133-1143.

- Brach, T.(2003). Radical acceptance: embracing your life with the . 235 :heart of a Buddha. New York: Banta

- Barnard,L. K. \&Curry,J.F.(2011).Self-Compassion: Conceptualizations, Correlates, \& Interventions. Review of General Psychology ,15,289-303.

- Benetti , C. \& Kambouro , P. (2006). Affect - regulated in direct effect of trait anxiety and trait resilience on self - esteem. Personality and individual differences , 341-352.

- Bluth K.\& Eisenlohr-Moul T.(2017).Response to a mindful selfcompassion intervention in teens:A Within-Person association of mindfulness,self-compassion,and emotional Well-being outcomes.Journal of Adolescence,57,108-118.

- Breines,J.\&Chen,(2012).Self-Compassion Increases SelfImprovement Motivation. Personality and Social Psychology Bulletin,38(9),1133-1143.

- Ellis A. \&Bernard , E. (2006).Rational Emotive Behavioral Approaches to Childhood Disorder .N Y: Kluwer Academic Plenum Publishers.

- Gilbert,P.\&Procter,S.(2006).Compassionate mind training for people with high shame and self-criticism: Overview and pilot study of a group therapy approach. Clinical Psychology\& Psychotherapy,13,353-379.

- Goetz,J.,Keltner ,D.\& Simon-Thomas,E.(2010).Compassion: An evolutionart analysis and empirical review . Psychological Bulletin,136,351-374.

- Iskender,M.(2011). The Relationship Between Self-compassion Selfefficacy and control Belief about learning in Turkish university students. Social Behavior and Personality ,37,(5),711-720.

- Janjani P.,Haghnazari 1.,Keshavarzi F.\& Rai A. (2017) The Role Of Self - Compassion Factors In Predicting the Marital Satisfaction Of Staff at Kermanshah University Of Medical Sciences . Journal Of Family Medicine ,15 (7),83 .

- Kajbafnezhad,Had\& Khaneh Keshi,Ali(2015).Predicting Personality Resiliency by psychological Well-Being and its 


\section{$1 \wedge 1$}

Components in Girl Students of Islamic Azad University Journal on Educational Psychology,v8,n4,11-15.

- Karakasidou E. \& Stalikas A.(2017). The Effecttiveness of a Pilot Self- Compassion Program on Well Being Components. Psychology, 8, 538-549 .

- Kirkpatrick,K. L.(2005). Enhancing Self- Compassion using a Gestalt two-Chair intervention . Unpublished Doctoral Dissertation.University of Texas at Austin TX,USA.

- Kristin D. Neff1 and Christopher K. Germer(2012). APilot Study and Randomized Controlled Trialof the Mindful Self-Compassion Program., journal of clinical psychologe Vol. 00(00), 1-17 (2012).

- Koen , D., (2010 ). Resilience I Professional nurses. Thesis doctor for philosophy, in psychology and the vaal triangle campus of the North - West University

- Kurilova,J.(2013).Exploration of Resilience in Relation to Mindfulness, Self-Compassion, and Attachment Styles. Unpublished MA thesis, in Applied Psychology, University of Calgary.Middle Tennessee State University.

- Kyeong,L.(2013).Self-Compassion as a Moderator of the Relationship between Academic Burn-out and psychological Health in Korean Cyber University Students .Personality and Individual Differences,54,899-902.

- Lightsey , O. R. (2006) . Resilience , Meaning, and well- being. The Counselling Psychologist, 34, 1, 96-107.

- Leary,M.,Tate,E.,Adams,C.\& Allen,A.(2007).Self-Compassion and reactions to unpleasant self relevant events : the implications of treating one self Kindly .Unpublished manuscript .

- Luthar, S.S \& Cicchettti , D., (2000). The construct of resilience : implications for interventions and social policies. Development and psychology.

- Masten, A.S. (2009). Ordinary Magic: Lessons from research on resilience in human development. Educational Canada, , 28- 32.

- Musalay P.\&Laliteshwari K.(2017)Self-compassion and cognitive emotion regulation among Juvenile delinquents.Indian Journal of Health and Well-being ,8(8),805-810.

- Nath , P. \& Pardham , R.K. (2012). Influence of positive effect on physical health and psychological well- being: Examining the mediating role of psychological resilience, Journal of health Management, 14, 2, 161- 174.

- Neff Kristin(2003a)The Development and Validation of a Scale to Measure Self-Compassion, Self and Identity, vol,2 (3); 223-250.

- Neff Kristin.(2003b). Self-compassion: an alternative conceptualization of a healthy attitude toward oneself. Self and Identity, vol 2.(2),pp; 85-101. 
- Neff Kristin, Kristin L. Kirkpatrick B, Stephanie S. Rude.(2007).Self- compassion and adaptive psychological functioning, Journal of Research in Personality ,vol, 41, 139-154.

- Neff, K. \& McGehee,P. (2010). Self-compassion and Psychological Resilience Among Adolescents and YoungAdults, Self and Identity ,vol, 9(3), 225-240.

- Neely M.,Schallert D.,Mohammed S., Roberts R.\&Chen Y.(2009).Self-Kindness when facing stress : The role of selfcompassion, goal regulation and support in college students wellbeing. Motiv Emot 33,88-97.

- Neef,K.\&Costigan,A.(2014).Self- compassion,Wellbeing and Happiness.Psychologie in Osterreich,2,3,114-119.

- Neff,K.\&Beretvas,S.(2012). The role of self-compassion in romantic relationships.Self and Identity, Retrieved doi: 10.1080115298868.2011.639548.

- Potter,R. Yark,Francis,A.\& Schuster,S.(2014). Self-Compassion Mediates the Relationship between Parental Criticism and Social Anxiety. International Journal of Psychology and Psychological Therapy, 14,1,33-43.

- Raes,F.,Pommier,E., Neff,K. D. \& Van Gucht, D.(2011). Construction and factorial validation of a short form of the SelfCompassion Scale. Clinical Psychology \& Psychotherapy. 18, 250255.

- Richardson,G.(2002).The metatheory of resilience and resiliency. Journal of Clinical Psychology,58(3),307-321.

- Sahin Kapikiran (2016). Optimism and psychological Resilience in relation to Depressive Symptoms in University Students Examining the Mediating Role of Self-Esteem.110-287.

- Sabaityte E. \& Dirzyte,A.(2016).Psychological Capital , SelfCompassion, And Life Satisfaction Of Unemployed Youth .International Journal of psycology :Biopsychosocial Approach $, 19,49$.

- Smith, B., Dalen, J., Wiggins , K., Tooley , E., Christopher,P , \& Bernard, J. (2008). The brief resilience scale: Assessing the ability to bounce back, International of Behavioural Medicine, 15, 194200 .

- Stein , M. (2005). Resilience and young people leaving care overcoming the odds, Research Report Joseph Rowan tree Foundation York.

- Landgraf,A.(2013). Under Pressure: Self-Compassion as a Predictor of Task Performance and Persistence. UNF Thses and Dissertations.453.

- Lu\&Wang,Y.(2014). Life Stress and Academic Burnout. Active Learning in Highe Education.5.1.77-90 


\section{$1 \wedge \mu$}

- Thompson L. B \& Waltz J.(2007). Everyday Mindfulness and Mindfulness meditation : Overlapping constructs or not? Personality and Individual Differences,Vol,43,(7),1875-1885.

- Thimm Jens C.(2017).Relationships between Early Maladaptive Schemas, Mindfulness, Self-compassion, and Psychological Distress .international Journal of Psychology and Psychological Therapy,17,1,3-17.

- Thimm Jens c.(2017).Relationships between Early Maladaptive Schemas, Mindfulness, Self-Comassion, and Psychological Distress. International Journal of psycology and psychosocial Therapy,17,1,3-17.

- Tobias Krieger,Dominik Sander Martig ,Erik van den Brink ,Thomas Berger (2016). Working on self-compassion online: A proof of concept and feasibility study. Internet Interventions 6 (2016) 64-70.

- Trompetter HR , de Kleine E,Bohlmeijer ET(2017) why does positive mental health buffer against psychopathology ? An exploratory study on self - compassion as a resilience mechanism and adaptive emotion regulation strategy . cogn Ther Res 41: 459468.

- Van, G. M., De puijter , M., \& Smeets , C. (2006). Citizens and resilience Amsterdam : Dutch Knowledge and Advise center.

- Wang,S.(2005). Aconceptual framework for integrating research related to the physiology of compassion and the wisdom of Buddhist teaching. In,P.Gilbert (Ed).Compassion:Conceptualisations,research and use in psychotherapy (p.75-120).London:Brunner- Routledge.

- Walker laaurie Hollis- and Colosimob, (2011) Mindfulness, self Compassion, and happinss In non-meditators : A theoretical and empirical examination, personality and Individual Differences, Vol,50,(2),pp:222-227.

- Wicks, C. R. (2005) Resilience: An integrative Frame work measurement, Loma Linda University.

- William, H, David , Hhn , (2001) Usand well. Being in older widows, Adaptation and Resilience, Journal of women Aging, 23.

- Wright, M., Masten,A.,\&Narayan,A.(2013). Resilience Processes in Development: Four Waves of Research on positive Adaptation in the Context of Adversity. In S. Goldstein and R. Brooks (Eds.),Handbook of Resilience in Children(15-37),New Yorkq.

- Ying, Y.(2009). Contribution of self- compassion to competence and mental health in social work students.Journal of Social Work Education,45(2),309-323.

- Zabelina, Darya. And Robinson, Michael .D (2010) Don,t Be so Hard on Your Salf : Self - Compassion facilitates Creatve Originality Among Salf - judgmental individuals Creativity Research Journal,vol,22(3),pp:288-293. 